Universidade de São Paulo

Faculdade de Educação

Maria Letícia Barros Pedroso Nascimento

Educação Infantil e Sociologia da Infância.

Estudo sobre as relações entre a pesquisa em Estudos da Infância e os contextos nos quais é realizada

São Paulo 
Maria Letícia Barros Pedroso Nascimento

Educação Infantil e Sociologia da Infância.

Estudo sobre as relações entre a pesquisa em Estudos da Infância e os contextos nos quais é realizada

\begin{abstract}
Tese apresentada como exigência parcial do concurso para obtenção do título de livre-docente junto ao Departamento de Metodologia do Ensino e Educação Comparada da Faculdade de Educação da Universidade de São Paulo.
\end{abstract}

São Paulo 


\section{Educação Infantil e Sociologia da Infância. Estudo sobre as relações entre a pesquisa em Estudos da Infância e os contextos nos quais é realizada}

Tese apresentada como exigência parcial do concurso para obtenção do título de livredocente junto ao Departamento de Metodologia do Ensino e Educação Comparada da Faculdade de Educação da Universidade de São Paulo

Aprovado em:

Banca Examinadora

Prof. Dr.

Instituição:

Assinatura:

Prof. Dr.

Instituição:

Assinatura:

Prof. Dr.

Instituição:

Assinatura:

Prof. Dr.

Instituição:

Assinatura:

Prof. Dr.

Instituição:

Assinatura: 
Aos meus pais (in memoriam)

Ao Guilherme, meu filho, e à Adriana, minha nora

À Luísa, minha neta 


\section{Agradecimentos}

O principal problema de fazer agradecimentos é o fato que são muitas as pessoas a agradecer numa trajetória de quase quinze anos, e, fatalmente, uma ou outra será esquecida.

Ciente disso, agradeço aqui aos muitos que colaboraram para que pudesse produzir essa tese, a começar pelo Guilherme Nafalski, meu filho, que se tornou um bom interlocutor na discussão sobre a Sociologia além de oferecer significativo apoio em diferentes momentos.

Agradeço às orientandas/os e não orientandas/os que fazem parte do Grupo de Estudos e Pesquisa Sociologia da Infância e Educação Infantil (GEPSI), particularmente à Bruna Breda, cuja convivência acadêmica já tem oito anos e passa por inúmeras parcerias de meio de caminho, e à Celia Serrão, que já nem sei mais quando conheci, só sei que foi no contexto da educação infantil. Em nome delas, agradeço a todos, mesmo os recémchegados e aqueles que se afastaram do grupo.

Agradeço a Jens Qvortrup, pela generosidade, pela acolhida e pela confiança. Agradeço também à Jo Moran-Ellis pelos mesmos motivos e pela parceria. Pelas discussões lúcidas e a franca acolhida, agradeço ao Heinz Sünker. Não posso deixar de agradecer ao Manuel Sarmento, também um parceiro de primeira qualidade. Quero agradecer a todos os colegas estrangeiros que concordaram em ser entrevistados para a pesquisa, com quem estabeleci excelentes contatos.

Agradeço ainda os colegas da FEUSP que torceram para que a bolsa de pesquisa no exterior saísse e aqueles com quem tenho boas interlocuções sobre o campo da Sociologia e o da Educação Infantil. Agradeço aos amigos e amigas que têm compartilhado comigo as boas e não tão boas notícias.

Agradeço à FAPESP, cuja bolsa de pesquisa permitiu a realização da pesquisa. Agradeço ao CNPq, ao UGPN e à FEUSP pelo apoio à realização de pesquisas.

Agradeço à Luísa Aguiar Nafalski, em nome de quem agradeço a todas as crianças, pelas quais vale a pena estudar tanto... 


\section{Resumo}

NASCIMENTO, Maria Letícia B. P. Sociologia da Infância e Educação Infantil. Estudo sobre as relações entre a pesquisa em Estudos da Infância e os contextos nos quais é realizada. Tese (Livre-Docência). Faculdade de Educação, Universidade de São Paulo, São Paulo, 2015

Esta tese pretende recuperar os quase quinze de interlocução entre a Educação Infantil e o campo da Sociologia da Infância. O compromisso com o desenvolvimento de um trabalho científico no campo, com vistas a institui-lo e constitui-lo na FEUSP, passou pela formulação de disciplina e de projetos de pesquisa, por aulas, orientações, palestras, cursos e produção de artigos que busco incorporar ao estudo. O texto se inicia por uma breve menção ao percurso acadêmico, com a finalidade de explicitar o lugar de onde falo, segue para uma Introdução, que busca apresentar algumas das ideias e reflexões que serão destaques na maior parte da tese, evidenciando a infância em direção à educação infantil e as relações com a Sociologia da Infância. O primeiro capítulo trata da própria Sociologia da Infância, o desenvolvimento do campo, as diferentes abordagens, algumas divergências teóricas. O segundo não pretende esgotar o que se tem realizado de pesquisa na e sobre a sociologia da infância, mas pretende oferecer um panorama sobre o tema, acrescido, na sequência, de breve discussão sobre a interface entre a educação infantil e a sociologia da infância. O terceiro capítulo abre espaço para a pesquisa inédita, realizada no primeiro semestre de 2014 , em centros de pesquisa da infância localizados em quatro países europeus. No quarto capítulo, considero e analiso os centros a partir de uma síntese dos contextos onde se inserem, da perspectiva da interdisciplinaridade e da produção de teoria. Finalizo considerando alguns pontos, produzidos na pesquisa, e abrindo a possibilidade de novas pesquisas.

Palavras-chave: Estudos da Infância. Centros de pesquisa. Sociologia da Infância. Educação Infantil 


\begin{abstract}
NASCIMENTO, Maria Letícia B. P. Sociology of Childhood and Early Childhood Education. Relations between research in Childhood Studies and the contexts in which it operates. Thesis (Livre-Docência). Faculty of Education. Universidade de São Paulo, São Paulo, 2015.
\end{abstract}

This thesis aims to recover nearly fifteen years of dialogue between early childhood education and the field of sociology of childhood. The commitment to the development of a scientific work in the field, with a view to establishing it in FEUSP, provoked a design of a discipline and some research projects; classes, advisement, lectures, courses and papers about it. The text starts by a brief mentioning of my academic route, in order to explain the place from which I speak. The Introduction presents some ideas and reflections that will be in most of the thesis, showing childhood toward early childhood education and the relations with the sociology of childhood. The first chapter deals with the sociology of childhood itself, the development of the field, the different approaches, and some theoretical differences. The second aims to provide on an overview about the sociology of childhood and a brief discussion on the interface between early childhood education and the sociology of childhood. The third chapter focuses an original research, conducted in the first half of 2014, in centres of research on childhood located in four European countries. The fourth chapter considers and analyses the centres from a synthesis of the contexts in which they operate, from the perspective of interdisciplinarity and production of theory. I conclude by considering some points produced in this research, and opening the possibility of new studies.

Key words: Childhood Studies; Centres of research; Sociology of Childhood; Early Childhood Education 


\section{Sumário}

Apresentação

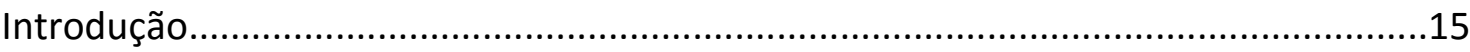

O lugar da educação infantil na vida das crianças pequenas.........................................18

1. Sociologia da Infância como campo de pesquisa e produção de conhecimento.........24

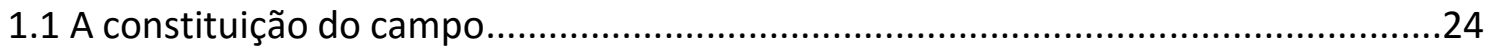

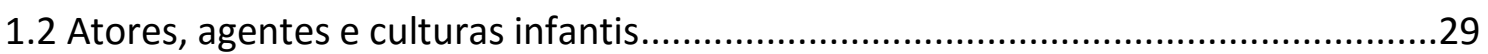

1.3 "Marginalidade e voz": notícias sobre a Sociologia da Infância como campo de

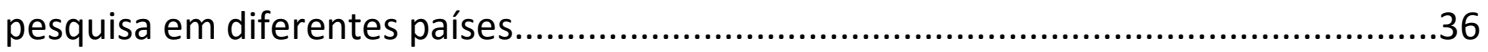

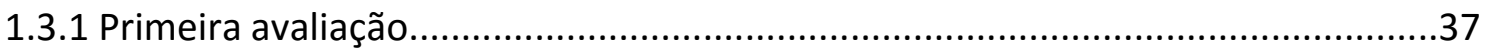

1.3.2 A situação da infância e o desenvolvimento da Sociologia da Infância: os relatos

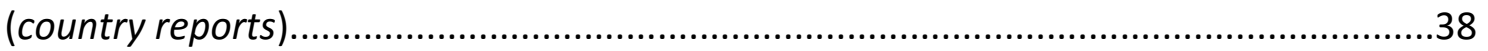

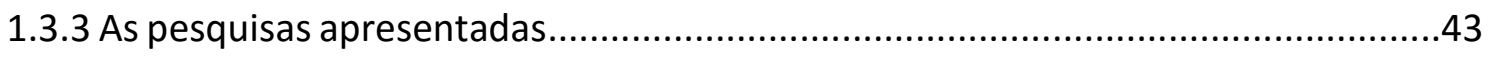

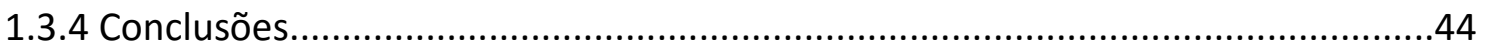

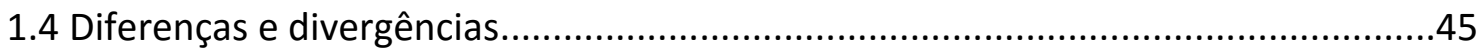

1.4.1 Pontos de vista, divergências e diferenças no campo da Sociologia da Infância anglófona.

2. Alguma informação sobre pesquisa em Sociologia da Infância no Brasil....................51

2.1 A interface entre Sociologia da Infância e Educação Infantil.....................................54

2.1.1 Primeiros achados.....

3. As relações entre a pesquisa em Estudos da Infância e os contextos nos quais é realizada .62

3.1. Na Universidade de Sussex, Inglaterra.............................................................64

3.1.1. Centre for Innovation and Research in Childhood and Youth (CIRCY) ...................72

3. 2. Centros interdisciplinares de pesquisa em infância............................................75

3.2.1. Centro de Investigação em Estudos da Criança (CIEC), Universidade do Minho,

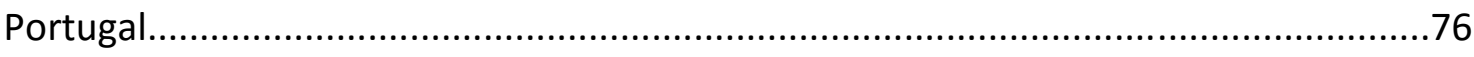

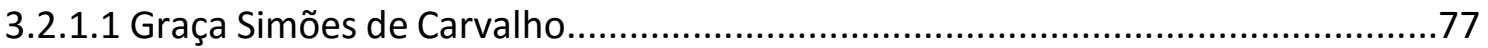


3.2.1.2 Manuel Jacinto Sarmento .80

3.2.1.3 Grecia Rodriguez Pinto

3.2.2. Interdisziplinären Zentrums Kindheiten.Gesellschaften (IZKG), Bergischen Universität Wuppertal .89

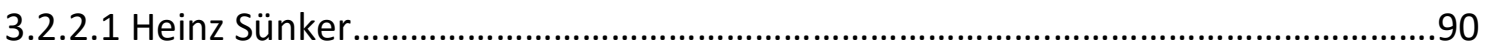

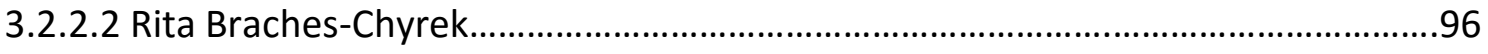

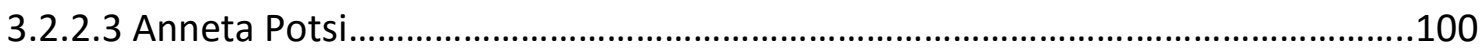

3.2.3. Norwegian Centre for Child Research (NOSEB), Norwegian University of Science

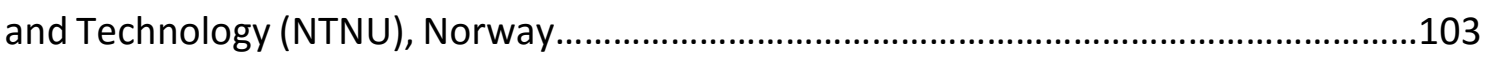

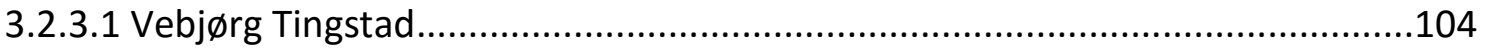

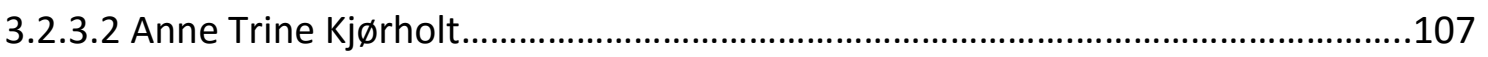

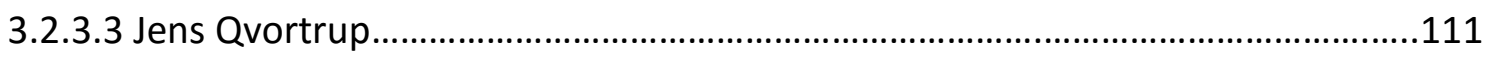

3.2.4. Centre for the Study of Childhood and Youth (CSCY), University of Sheffield, UK

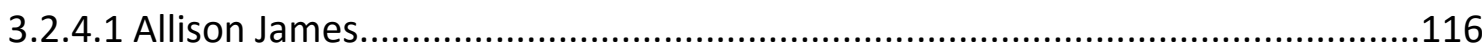

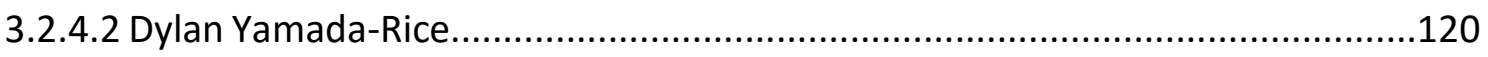

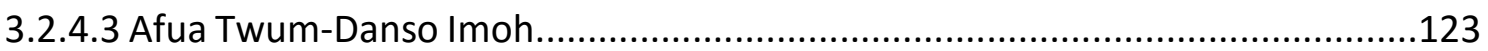

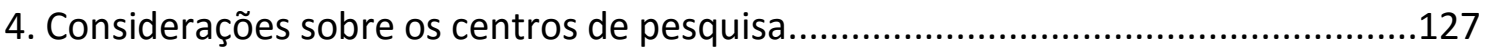

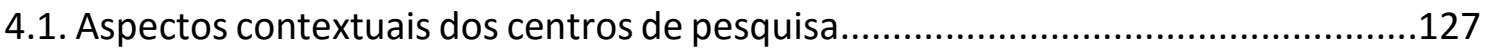

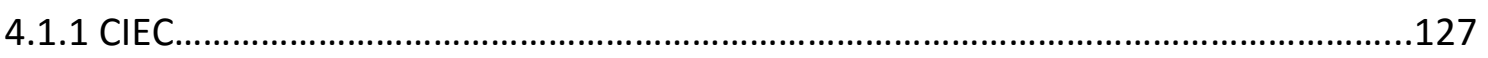

4.1.2 Interdisciplinary Center Childhoods.Societies........................................................129

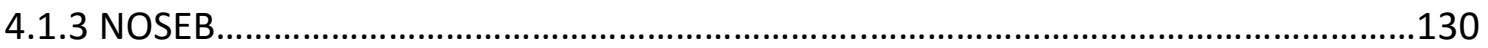

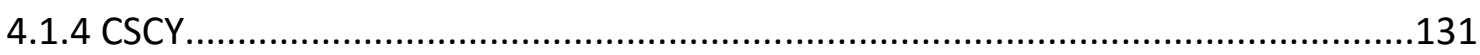

4.2. Interdisciplinaridade: princípio e/ou abordagem teórico-metodológica................132

4.3. O que pode ser particular no estudo de infância?................................................139

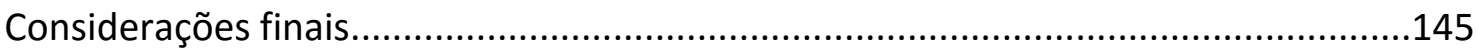

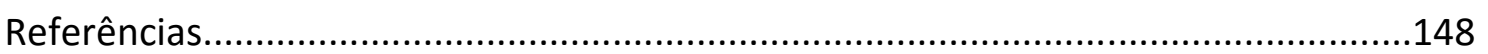




\section{Apresentação}

Tive muitas dúvidas sobre como realizar uma tese de livre-docência. Afinal, no que consiste uma tese de livre-docência? Via de regra, esta tese se constrói a partir do doutorado, pretendendo refletir, discutir, revelar o percurso intelectual-acadêmico realizado pelo pesquisador-docente. Quase como olhar para o espelho e se dar conta do que ele reflete. O que reflete um espelho frente a mais de quinze anos de atuação no ensino superior? Vou voltar um pouco no tempo, na tentativa de compreender o que fundamenta esse percurso.

Uma das primeiras imagens/impressões/constatações ao recuperar/rever esse tempo/percurso é que gosto de perseguir uma nova ideia, uma outra possibilidade de fazer o que já está sendo feito e, quem sabe, mudar. Foi assim quando, no início da carreira, ainda professora do ensino fundamental municipal, persegui uma outra maneira de trabalhar com as crianças, acumulando o trabalho na rede pública com o desenvolvido em escola, naquela época, denominada alternativa. Desafio, outras possibilidades de trabalho, novos textos, estudos, a construção de uma prática mais satisfatória profissionalmente. A prática, contudo, parecia pouco ou parte. Era preciso mergulhar em ideias, conceitos, esclarecer questões, compreendê-las. Quais as alternativas?

As crianças. A defesa das crianças como pessoas, que constroem identidades, pessoas diversas, inseridas em diferentes culturas. Diverso o processo de ensinar e aprender: recíproco, ainda que responsabilidade do profissional adulto. As crianças pequenas... quem são? Como entender a(s) linguagem(ns) que não vem das palavras? 
Assim, anos depois, já envolvida com a educação de crianças pequenas, de novo, busquei romper com o que sabia sobre essas crianças, cuja base era estabelecida pela Psicologia e pela Educação e, no início do doutorado, fui atrás de outros estudos que me ajudassem a compreender as relações sociais/educativas que pretendia analisar. Foi quando me deparei com um texto que, pela provocação que constituía, fez com que começasse a repensar a base teórica que me movia, os escritos de Wallon, compreendendo que esta não era suficiente para dar conta do estudo que pretendia realizar. O texto em questão, de 1995, Childhood in Europe: a New Field of Social Research, de Jens Qvortrup ${ }^{1}$, sociólogo dinamarquês, apresentava uma ideia interessante sobre a infância e alguns paradoxos sobre as relações entre adultos e crianças na contemporaneidade, indicando uma nova área de estudo e produção de conhecimento, a Sociologia da Infância.

Interessante pensar que, à época, já professora do ensino superior, construí um capítulo da tese de doutorado nas aulas que dava para uma determinada turma, para a qual trazia elementos teóricos da Sociologia da Infância para discussão e, preciso dizer, crescíamos juntas, eu e as alunas, a debater aquilo que parecia vanguarda, ainda mais no contexto da educação infantil.

Em relação aos estudos do Prof. Qvortrup, do contato inicial, por meio de correio eletrônico, e a consequente ampliação das leituras, a partir de sugestões enviadas por ele ou da busca dos textos que constituíam suas referências bibliográficas, passei a

\footnotetext{
${ }^{1}$ Produzi, a convite da Profa. Dra. Teresa Rego, da FEUSP, um texto dedicado à apresentação de Jens Qvortrup como pesquisador da infância, publicado na Revista Educação, número especial Cultura $e$ sociologia da infância, em 2012(a).
} 
incorporar suas nove teses ${ }^{2}$ ao estudo das crianças pequenas na produção de pesquisa, e, assim, fui participando em congressos, seminários e encontros, internacionais e nacionais, do campo da Sociologia da Infância. Já docente da Faculdade de Educação da Universidade de São Paulo (FEUSP), propus o desenvolvimento de uma disciplina específica para a pós-graduação em educação, denominada Sociologia da Infância e Educação Infantil. Em outras palavras, compreender, realizar pesquisa e divulgar o campo tornou-se um projeto intelectual-acadêmico profissional.

Ao longo destes quase quinze anos de convivência com a Sociologia da Infância, com o compromisso do desenvolvimento de um trabalho científico no campo, um dos desafios que enfrentei foi institui-lo e constitui-lo na FEUSP. Aulas, palestras internas e externas, participação em cursos e em disciplinas ministradas por colegas - quantos textos produzidos para essas atividades, alguns inéditos e outros não -, vários textos publicados, todo um material que dá conta do percurso e que busco incorporar a essa tese.

Na FEUSP, além da disciplina, organizei um grupo de estudos e pesquisa, o Grupo de Estudos e Pesquisa sobre Sociologia da Infância e Educação Infantil (GEPSI), a vinda de pesquisadores internacionais e nacionais para ministrarem cursos e/ou palestras ou

\footnotetext{
2 1. A infância é uma forma particular e distinta em qualquer estrutura social de sociedade; 2 . A infância não é uma fase de transição, mas uma categoria social permanente, do ponto de vista sociológico; 3 . A ideia de criança, em si mesma, é problemática, enquanto a infância é uma categoria variável histórica e intercultural; 4. A infância é uma parte integrante da sociedade e de sua divisão de trabalho; 5 . As crianças são coconstrutoras da infância e da sociedade; 6. A infância é, em princípio, exposta (econômica e institucionalmente) às mesmas forças sociais que os adultos, embora de modo particular; 7. A dependência convencionada das crianças tem consequências para sua invisibilidade em descrições históricas e sociais, assim como para a sua autorização às provisões de bem-estar; 8. Não os pais, mas a ideologia da família constitui uma barreira contra os interesses e o bem-estar das crianças; 9. A infância é uma categoria minoritária clássica, objeto de tendências tanto marginalizadoras quanto paternalizadoras (QVORTRUP, 2011a[1993]).
} 
participarem de seminários e similares, a orientação e a realização de pesquisas, dentre as quais cabe destacar Infância e Sociologia da Infância: entre a invisibilidade e a voz. Esta pesquisa, de âmbito nacional, financiada pelo $\mathrm{CNPq}^{3}$, realizada pelo $\mathrm{GEPSI}$, sob minha coordenação, levantou os grupos de pesquisa que trabalham/produzem conhecimento em Sociologia da Infância. Seus resultados foram apresentados em eventos nacionais e internacionais, e, além de oferecerem um panorama do campo no Brasil, provocaram a elaboração de outros projetos de pesquisa ${ }^{4}$, dentre os quais aquele cujo desenvolvimento produziu a pesquisa apresentada no terceiro capítulo desta tese. Trata-se de pesquisa inédita, realizada no primeiro semestre de 2014 , em território europeu, em quatro centros de investigação.

Curiosamente, a imagem/sensação/constatação referente à realização dessa pesquisa é a do encerramento de um ciclo de estudos e produção de pesquisa realizado numa relação estreita com a produção europeia. Não se trata, é claro, de romper os contatos europeus e norte-americanos, mas de voltar-me principalmente ao nosso continente, produzir pesquisa com outros países da América do Sul, trocar textos, orientandos, visitas. Quem sabe ter fôlego para estabelecer uma rede.

Apresentado esse breve percurso, parece-me prudente indicar o caminho da tese. Há uma introdução, que busca apresentar algumas das ideias e reflexões que serão destaques na maior parte da tese, evidenciando a infância em direção à educação

\footnotetext{
3 Processo CNPq no 400829/2010-0. Edital MCT/CNPq/MEC/CAPES no 02/2010 - Ciências Humanas, Sociais e Sociais Aplicadas.

${ }^{4} \mathrm{O}$ doutorado de Monique Aparecida Voltarelli, Estudos da infância na América do Sul: concepções $e$ produções na perspectiva da sociologia da infância, em andamento, sob minha orientação, também é decorrência desse movimento.
} 
infantil e as relações com a Sociologia da Infância. Recupero e modifico parcialmente textos mais antigos e introduzo elementos que os reveem.

O tema do primeiro capítulo é a própria Sociologia da Infância, o desenvolvimento do campo, as diferentes abordagens, algumas divergências teóricas. Neste capítulo, concentra-se a maior parte dos textos que venho escrevendo ao longo do tempo, alguns inéditos, e que são o retrato da busca do entendimento do campo.

O segundo capítulo recupera a pesquisa realizada pelo GEPSI e as informações sobre a pesquisa em Sociologia da Infância no Brasil.

O terceiro abre espaço para a pesquisa inédita, realizada no primeiro semestre de 2014 , em centros de pesquisa da infância localizados em quatro países europeus.

No quarto capítulo considero e analiso os centros a partir de uma síntese dos contextos, da perspectiva da interdisciplinaridade e da produção de teoria.

Finalizo considerando alguns pontos, produzidos na pesquisa, abrindo a possibilidade de novas pesquisas. 


\section{Introdução}

Falar de Educação Infantil ou de Sociologia da Infância sem apresentar as concepções que têm definido as crianças e os processos pelos quais pode-se compreender a infância parece inadequado. Como ${ }^{5}$ sustenta o sociólogo britânico Chris Jenks, no texto Constituindo a criança (2002), na medida em que se constrói uma imagem de infância, esta corresponde a uma imagem da adultez ${ }^{6}$, ou melhor, "a criança não é imaginada senão em relação a uma concepção de adulto, embora seja impossível criar uma noção precisa da adultez e da sociedade adulta sem primeiro tomar em consideração a criança" (p.187), o que estabelece o princípio de reciprocidade. Nesta linha, se o projeto de modernidade privilegia a razão e o conhecimento objetivo, considerados como características do adulto, as crianças serão reconhecidas como seres inacabados, incompletos, como potenciais a serem desenvolvidos para atingir a plenitude, um dia. Ainda de acordo com Jenks (2002), foi evidenciada uma certa inquietação da sociedade adulta em relação à infância, pois, se por um lado prevalece a sensação de semelhança, visto que as crianças tornar-se-ão adultos $^{7}$ um dia, por outro, estabelece-se um estranhamento em relação à forma infantil de lidar com o mundo. Assim, ao longo dos séculos, foram sendo elaboradas variadas explicações sobre as diferenças entre as crianças e os adultos - ou concepções de infância -, por diversos pensadores.

Os sociólogos britânicos James, Jenks e Prout (2004) apresentam essas concepções como imagens. A imagem da criança má resulta, segundo os pesquisadores, de uma

\footnotetext{
${ }^{5}$ Este texto apresenta trechos de uma nova versão de artigo publicado em 2009, A infância invisível.

${ }^{6}$ Termo emprestado ao português de Portugal, visto que não temos equivalente no português brasileiro.

${ }^{7}$ Destaque-se aqui a ideia de infância como tempo de passagem, como vir-a-ser.
} 
representação que compreende que a criança, por estar próxima da natureza e do pecado original, é um ser dotado de (maus) instintos, que devem ser controlados para o bem social. A da criança imanente foi criada por Locke, que construiu uma tese sobre cognição e aquisição de conhecimento, esta obtida por meio da percepção sensorial, da experiência, tendo como pano de fundo o projeto de futuro da sociedade. A criança inocente, por sua vez, é uma imagem criada por Rousseau de uma criança plena de bondade natural, que deve ser preservada. Pode-se dizer que tanto Locke quanto Rousseau atribuíram características à infância ao mesmo tempo em que atribuíram significado à intervenção dos adultos no processo de formação das crianças. "Tais características, baseadas na concepção de natureza infantil - temporal e dependente encobriu as relações concretas estabelecidas entre crianças e adultos, nos diferentes contextos sociais". (NASCIMENTO, 2009, p.47)

Outra concepção, ou imagem, destacada pelos sociólogos, é a da criança em desenvolvimento natural, que tem em Piaget seu principal representante. Diretamente ligada a processos de maturação, define os caminhos que toda e qualquer criança deve percorrer até chegar à vida adulta, numa sequência previsível. Nesta linha, a infância é considerada como período transitório no qual meninos e meninas internalizam passivamente a cultura social, um tempo de passagem, e o percurso do desenvolvimento infantil está fundamentado nas mudanças nas disposições do indivíduo: "da imaturidade (por exemplo, sexual) à maturidade, da incompetência (por exemplo, cognitiva) à competência, da incapacidade (por exemplo, motora funcional) à capacidade, e assim por diante" (QVORTRUP, 2010a, p.635). O propósito da educação, então, é superar a infância com sucesso (QVORTRUP, 2010a). “A noção de norma presente nessa concepção teria um caráter descritivo e um caráter moral, discriminando 
o bom do mau caminho a ser percorrido. Alcançar o pensamento operativo e ser um adulto racional justificam a ação sobre a infância" (NASCIMENTO, 2009, p.48).

Segundo Jenks (2002) "o status da infância tem suas fronteiras mantidas pela cristalização das convenções e discursos presentes nas formas institucionais que com ela lidam, como as famílias, creches, escolas e consultórios/clínicas, todas estas, agências designadas e estabelecidas para processar a infância como uma entidade uniforme" (p.5). Além disso, por um lado, as crianças foram reconhecidas pelo aspecto negativo, em relação ao adulto, e, por outro, a crescente atenção à infância e suas necessidades definiu seu confinamento em instituições específicas, o que acabou por torna-la invisível socialmente.

Uma nova concepção da infância, as crianças como sujeitos de direito e atores sociais, se forma a partir de três movimentos, na segunda metade do século XX: (1) a legislação internacional - e nacional - que institui os direitos das crianças e as reconhece como sujeitos (Constituição Federal (CF) de 1988; Convenção dos Direitos da Criança (CDC), 1989; Estatuto da Criança e do Adolescente (ECA), 1990; Lei de Diretrizes e Bases da Educação Nacional (LDBEN), 1996); (2) a divulgação/repercussão da Pedagogia das Relações praticada nas creches e escolas infantis do norte da Itália (MALAGUZZI, 1999; RINALDI, 1999, 2007); (3) a constituição do campo da Sociologia da Infância em países da Europa e nos Estados Unidos (CORSARO, 1979; JENKS, 1982; QVORTRUP, 1987; ALANEN, 1988). Destaque-se uma significativa alteração nos horizontes da educação infantil a partir da legislação nacional, que a inseriu no campo da Educação Básica, como primeira etapa, e, portanto, destacou creche e pré-escola como direito educacional e social, complementada por experiências e pesquisas internacionais construídas a partir 
da consideração das crianças como sujeitos, capazes de voz, significados, relações

interpessoais. Nesta linha, considera-se que

As crianças, mesmo pequenas, são sujeitos ativos e competentes, com características diferentes dos adultos, cujas ideias e teorias que devem ser ouvidas e questionadas, num tratamento diferente daquele que é dado quando se caracteriza a infância como ausência de características (supostamente) próprias do ser humano adulto. Elas pertencem a diferentes classes sociais, ao gênero masculino ou feminino, a um espaço geográfico onde residem, à cultura de origem e a uma etnia. Ou seja, são crianças concretas e contextualizadas. São membros da sociedade. Existem nas famílias, nas escolas, nas creches e em outros espaços. Não são inocentes ou más, mas são seres humanos. Fazem parte do mundo como ele é, o incorporam, são por ele influenciadas e, ao mesmo tempo, o influenciam e criam significados a partir dele. (NASCIMENTO, 2009, p.53).

Desde os anos 1980, os estudos da infância reconhecem as crianças como pessoas concretas e contextualizadas, submetidas aos mesmos problemas que atingem o grupo social do qual fazem parte. Seu reconhecimento como atores sociais de pleno direito faz parte do novo paradigma da infância, sintetizado por James e Prout $^{8}$, em 1990.

\section{0 lugar da educação infantil na vida das crianças pequenas ${ }^{9}$}

Os estudos e pesquisas nacionais e internacionais realizados nas instituições de educação infantil, tendo como referencial teórico metodológico ou a pedagogia das relações malaguzziana ou a Sociologia da Infância, têm fortalecido a imagem de criança competente e destacado seu papel nas relações sociais e educativas. Dessa forma,

\footnotetext{
${ }^{8} 1$. A infância é uma construção social; 2 . A infância é variável e não pode ser inteiramente separada de outras variáveis como a classe social, o sexo ou o pertencimento étnico; 3 . As relações sociais das crianças e suas culturas devem ser estudadas em si; 4 . As crianças são e devem ser estudadas como atores na construção de sua vida social e da vida daqueles que as rodeiam; 5. Os métodos etnográficos são particularmente úteis para o estudo da infância; 6 . A infância é um fenômeno no qual se encontra a dupla hermenêutica das ciências sociais evidenciada por Giddens, ou seja, proclamar um novo paradigma no estudo sociológico da infância é se engajar num processo de reconstrução da criança e da sociedade (JAMES; PROUT, 1990, p.8-9, grifo no original).

${ }^{9}$ Texto produzido para a Conferência I, do Congresso Paulista de Educação Infantil (2012c), nunca publicado.
} 
estabelece-se uma contraposição ao adultocentrismo ${ }^{10}$, presente nas instituições voltadas à infância, que acabou por tornar mínima a possibilidade de participação das crianças.

Em relação à educação infantil, verifica-se uma crescente institucionalização das crianças pequenas, evidenciada pelos números da demanda e das matrículas na educação infantil, notadamente nos centros urbanos ${ }^{11}$. É inegável que, se por um lado, esse aumento é motivado pelo trabalho feminino, por outro, indica que esse espaço institucional é o contexto social onde há oportunidade de relacionamento cotidiano com outros meninos e meninas. Essa constatação, entretanto, provoca uma série de questões.

Uma delas relaciona-se com as políticas de educação infantil desenvolvidas pelos municípios. Não é novidade - e há várias pesquisas que nos alertam - que a educação infantil está sendo lugar de preparação para a escolarização formal, ou seja, foi estabelecida uma relação direta entre a educação infantil e mudanças de ordem social mais ampla, como o melhor desempenho das crianças na educação fundamental desencadeando melhorias no emprego e na renda da população - no futuro. A ideia de educação infantil como investimento social, cujas vantagens para as classes de baixa renda se revelam pelo tempo maior que pais e principalmente mães terão para investir em seu trabalho e, assim, gerar mais renda, e, por que não, pela expectativa de que as próprias crianças possam ter empregos melhores a partir do tempo de preparação na

\footnotetext{
${ }^{10}$ Em 1976, Fulvia Rosemberg tratava dessa questão no artigo Educação para quem?

${ }^{11}$ De acordo com o censo escolar de 2011, o número de crianças matriculadas em creches estava acima de 2 milhões e, em pré-escolas, correspondia a 4,65 milhões, o que indicava um crescimento de $8,5 \%$ no número de matrículas em creches públicas.
} 
escola. Esta lógica, sustentada pela combinação entre teorias da Neurociência, da Psicometria e da Economia ${ }^{12}$, tem sido mais e mais disseminada, embora nos EUA, onde surgiram os estudos de intervenção precoce, as taxas de pobreza entre as crianças estejam 22\% mais altas em 2010 do que em 1965, quando o programa Head Start começou (MOSS, 2012).

A relação direta entre o investimento na educação infantil e a redução da desigualdade social remete aos anos 1970 e à concepção de educação compensatória ${ }^{13}$. Além disso, ignora a complexidade do tecido social, das relações de poder e da economia.

Outra das questões provocadas pela crescente institucionalização das crianças pequenas é levantada por Fortunati (2009): um descompasso entre as potencialidades das crianças e as oportunidades postas à sua disposição, que retira das crianças as conquistas obtidas a partir de seu reconhecimento como sujeitos de direitos. Está aqui em jogo a perspectiva da reciprocidade entre as concepções de criança e de adulto, retomando Jenks (2002). Nessa linha, se se acredita que todas as crianças, sob qualquer ponto de vista, são iguais, igual no sentido de uniforme, ou seja, nascem da mesma forma, crescem da mesma forma, aprendem da mesma forma, na perspectiva da criança universal, espera-se que superem a infância com sucesso (QVORTRUP, 2010a). Assim, o trabalho pedagógico acaba sendo restrito à rotina empobrecida dos "mais musculosos projetos de definição das prescritivas orientações educacionais" (FORTUNATI, 2009, p.37). Em outras palavras, crianças pré-conhecidas, previsíveis provavelmente facilitam

\footnotetext{
12 Ver Barros et al, 2011a e 2011b.

${ }^{13}$ Ver Kramer, 1995; Patto, 1993, por exemplo.
} 
a vida do professor, ao passo que crianças que se expressam precisam ser escutadas, o que cria uma relação pedagógica de outra qualidade.

Uma terceira questão refere-se à fragmentação da educação infantil causada pela Emenda Constitucional $59^{14}$, de 2009, que torna obrigatória a educação dos 4 aos 17 anos. Ao excluir as crianças de 0 a 3 anos dessa medida, abala a concepção de creche como espaço legítimo de educação e cuidado da criança pequena. Ainda que não se pretenda tornar a educação dos bebês obrigatória, visto que isso implicaria em tornar pública uma relação estabelecida na ordem do privado, pode-se pensar que a lei retira da família a possibilidade de escolha para as crianças de 4 e 5 anos. Dessa forma, a educação infantil fica dividida em duas, recuperando, de certa maneira, sua divisão histórica. Compromete a conquista da creche, que compõe o sistema educacional brasileiro. Leva também a pensar que o termo obrigatório pode remeter à possibilidade de a pré-escola ser compreendida como antecipação da escola, abalando a identidade - ainda frágil - da educação infantil.

A argumentação apresentada até aqui revela contradições significativas em relação às políticas voltadas à primeira infância e às crianças como sujeitos de direito. Nessa linha, retomando Moss (2012), cabe levantar algumas questões políticas essenciais: Qual é a concepção de infância? Qual é a concepção de educação infantil? Qual é o paradigma que norteia esse posicionamento? A clareza nas respostas vai indicar os diferentes contextos das instituições de educação infantil.

\footnotetext{
${ }^{14}$ Complementada pela Lei 12.796, de 4 de abril de 2013, que altera a LDBEN 9394, de 1996.
} 
Vandenbroeck (2012) reforça a idéia de que "processos de aprendizagem diferem dependendo dos contextos e que esses contextos refletem a diversidade de organização e funcionamento da sociedade em sua etnicidade, cultura, religião, gênero, composição familiar, competência etc." (p.15) E continua, afirmando que a educação de crianças pequenas é uma "questão de tomada de decisão, uma cadeia de múltiplas, pequenas, insignificantes e até altamente importantes decisões"(p.18) Decisões pautadas no dissenso, nas diferentes perspectivas que "desafiam nossos pressupostos tidos como certos" (p.19)

Fortunati (2009) aposta na Pedagogia dos Relacionamentos, na qual "os adultos têm responsabilidade sobre o acompanhamento e a segurança nas relações estabelecidas, reconhecendo as potencialidades de meninos e meninas e as oportunidades postas à sua disposição" (p.35).

Moss (2012), por sua vez, defende a democracia, "[como] um caminho de vida pessoal controlado não só pela fé na natureza humana em geral, mas pela fé na capacidade dos seres humanos para julgamentos e ações inteligentes se as condições adequadas forem fornecidas", como em Dewey, e a experimentação, ou seja, o

\footnotetext{
"desejo de inventar, de pensar de forma diferente, de imaginar e experimentar maneiras diferentes de fazer as coisas, de ir além do que já existe, para aventurar-se no ainda não é conhecido, que não deve ser vinculado ao dado, o familiar, o predeterminado, a norma; trabalhar com novos paradigmas, teorias, práticas; criar novas idéias, novos conhecimentos, novos projetos; afastar-se do pré-determinado, da previsibilidade, do resultado esperado; ter abertura para a diversidade, para a singularidade, para a surpresa."
}

Tendo em vista que meninos e meninas, em crescente quantidade, passam significativa parte de suas vidas, seus tempos de infância na educação infantil, qual a oportunidade que têm de viverem seus tempos de criança nas creches e pré-escolas? Talvez uma saída 
seja recuperar o que Moss e Petrie (2002) sugerem: as instituições de educação infantil organizadas não mais como serviços, mas como espaços das crianças, locais que "estabelecem potencial para muitas possibilidades - pedagógicas, emocionais, culturais, sociais, morais, econômicas, políticas, físicas e estéticas" (p.110). Nesses espaços, as crianças exercem a agência coletiva, que Corsaro $(2005,2009)$ identifica nas brincadeiras estabelecidas com os pares.

Para a educação infantil, a agência das crianças abre espaço para estudos sobre creche e pré-escola como locais onde meninos e meninas são ativos nas negociações que criam e recriam suas rotinas, onde as crianças exercem suas práticas sociais. O foco nas crianças possibilita que, embora sejam instituições, creche e pré-escola sejam percebidas não como simples locais de institucionalização da infância, mas espaço onde as crianças estabelecem relações entre pares e constroem culturas infantis. Cabe destacar que as contribuições da Sociologia da Infância ampliam a visibilidade das crianças pequenas, por um lado, e promovem uma reconfiguração da educação infantil, apresentando outros modos de compreender a infância, a socialização, as relações intergeracionais, por outro. 


\section{Capítulo 1}

\section{Sociologia da Infância como campo de pesquisa e produção de conhecimento}

Cabe destacar que tanto a Educação Infantil quanto a Sociologia da Infância foram reconhecidas como campo de conhecimento recentemente. Esse subcampo da Sociologia tem encontrado certa restrição acadêmica ao seu reconhecimento, embora tenha crescido em alguns países, inclusive com publicação de jornais e revistas específicas. Nesse sentido, à exceção de alguns países do norte europeu, a Sociologia da Infância aparece pontualmente como linha de pesquisa nas universidades e são poucos os trabalhos acadêmicos, publicados nos principais jornais especializados, que abordam principalmente os processos de socialização ou de instrução, o que leva a concluir que a infância tem ainda pouco espaço no debate teórico sociológico. (NASCIMENTO, 2011a, p. 35)

\subsection{A constituição do campo ${ }^{15}$}

Em recente ${ }^{16}$ visita ao Brasil, o sociólogo dinamarquês Jens Qvortrup nos ofereceu um volume da revista Eurosocial, de 1991, que contém a introdução à série de relatórios da pesquisa Infância como um fenômeno social, iniciada em 1987 e desenvolvida em 16 países ${ }^{17}$ do hemisfério norte. Liderada por ele, a pesquisa estabeleceu novo paradigma

\footnotetext{
${ }^{15}$ NASCIMENTO, M.L.B.P. Reconhecimento da Sociologia da Infância como área de conhecimento e campo de pesquisa: algumas considerações. In FARIA, A.L.G.de e FINCO, D. (Org.). Sociologia da Infância no Brasil. 1ed. Campinas: Autores Associados, 2011b, p. 37-54.

${ }^{16}$ Outubro de 2010.

${ }^{17}$ Canadá, Tchecoslováquia, Dinamarca, Inglaterra e País de Gales, Finlândia, Alemanha, Grécia, Irlanda, Israel, Itália, Noruega, Escócia, Suécia, Suíça, Estados Unidos e lugoslávia.
} 
para o estudo da infância, reconhecendo-a como um grupo social, a partir de ampla discussão sobre os paradigmas e abordagens disponíveis para compreender o bem-estar da criança, realizada por pesquisadores e pesquisadoras que participavam da investigação. Em encontros e seminários promovidos durante a pesquisa, entre 1987 e $1990^{18}$, temas como crianças em situação de risco, custódia familiar, políticas de cuidado e atenção, assistência às crianças e às famílias, questões encontradas na investigação, foram debatidos. Verificou-se que as abordagens destes temas partiam de paradigmas utilizados pela Psicologia ou pela Pedagogia, o que fazia predominar estudos sobre $a$ criança vista como um projeto de adulto, ou seja, questões formuladas a partir dos pressupostos psicológicos/pedagógicos faziam reconhecer tensões nas relações geracionais, com a predominância do adulto sobre a criança.

Os pesquisadores e pesquisadoras deram-se conta que, mesmo que fosse utilizada a sociologia, estudos e investigações eram dirigidos, sobretudo, para as instâncias encarregadas de socializar a criança, e focalizavam, na maioria das pesquisas, as categorias família e educação, grupos nos quais as crianças são tradicionalmente reconhecidas como dependentes e subordinadas. A infância como estágio preparatório, formativo, como tempo de passagem, ocultava as crianças no presente, nas relações sociais estabelecidas com adultos e outras crianças, todos sujeitos de mudanças históricas e sociais.

A constatação formulou um novo paradigma da infância, que caracteriza as crianças como um grupo populacional, numa perspectiva estrutural, o que significa utilizar a categoria geração para evidenciar as crianças como unidade de observação. Conceber a

\footnotetext{
${ }^{18} \mathrm{Em}$ 1990, a maioria dos pesquisadores do projeto compôs o então recém organizado Grupo Temático Sociologia da Infância, no XII Congresso Mundial da Associação Internacional de Sociologia (ISA).
} 
infância como construção social ou categoria estrutural promove a ideia de que ela "é uma estrutura permanente em qualquer sociedade, mesmo que seus participantes sejam regularmente repostos" (QVORTRUP, 1991, p.12, grifo no original). Sem o objetivo de competir com abordagens individualizantes ou desenvolvimentistas, a Sociologia da Infância vai focalizar as crianças enquanto são crianças, ou seja, refere "a próxima geração significando próxima geração de crianças. O ponto de vista antecipatório reitera o senso comum, que vê a infância, sociológica e economicamente, como relativamente desimportante se comparada à adultez ${ }^{19 \prime \prime}$ (QVORTRUP, 1991, p.14, grifos no original). Dessa forma, o paradigma recupera o impacto de questões políticas, econômicas, sociais, geográficas, históricas etc., que atingem crianças e adultos submetidos à mesma ordem de problemas. Trata-se, então, de estudar relações entre sujeitos contemporâneos e não mais entre seres maduros e em devir.

Além disso, a proposição altera o caráter natural e universal atribuído à infância na estrutura da sociedade. Revela a desigualdade na distribuição de poder, de recursos e de direitos entre adultos e crianças, presente nas relações sociais, políticas e econômicas, num cenário desenhado pelo mundo do trabalho, abolição do trabalho infantil e aumento da participação das mulheres no mercado; pela escolarização em massa; por uma ampliação do atendimento da primeira infância em creches; pelo interesse científico sobre a passagem das crianças para a idade adulta.

Do ponto de vista político, a infância representa a ideia de uma sociedade melhor, no futuro. Segundo Sarmento (2007), "uma concepção clássica de cidadania recusa o

\footnotetext{
${ }^{19}$ Em nosso português não há tradução literal para a palavra adulthood, mas, em português de Portugal, ela existe: adultez, palavra que será adotada nesse artigo para a referência ao grupo social que constitui a idade adulta.
} 
estatuto político às crianças" (p.39), sendo que se oferece à infância a condição de cidadãos em formação - para o futuro - por meio da escola. Paradoxalmente, as crianças são vistas como cidadãos do futuro, mas afastadas do espaço público no presente, ou seja, resguardadas de um pleno convívio social. Qvortrup (2010a) afirma que "manter as crianças fora da economia e da política é irrealista. Entre outras razões, isto é provado pelo fato de que as crianças são parte de um projeto que faz delas a matéria para a construção do futuro" (p.790).

As relações geracionais definem os lugares considerados apropriados ao desenvolvimento e/ou à socialização das crianças, onde elas não são reconhecidas em seus direitos, tampouco têm voz, mas são sempre representadas pelos adultos professores, pais e mães etc. Relacionada a uma lógica de proteção, essa prática social vem acompanhada de controle e, de acordo com Qvortrup (2011a), de uma atitude paternalista, que o sociólogo define como "uma estranha combinação de amor, sentimentalismo, senso de superioridade em relação à compreensão equivocada das capacidades infantis e marginalização" (p.210). Nas escolas e creches, o predomínio das vozes dos adultos contraria o princípio que sustenta que crianças e adultos têm o direito de serem ouvidos individual e coletivamente sobre as questões que os afetam e têm o direito de verem suas inquietações levadas a sério pela sociedade (MOSS; PETRIE, 2004).

A infância, posta à margem da sociedade, não impede, contudo, as crianças de participarem efetivamente do plano social, ainda que essa participação seja camuflada por seu pertencimento à família ou à escola. Nesse sentido, a infância não pode ser considerada como mero acessório da sociedade adulta porque as crianças 
outras razões: a primeira, por que elas fazem parte da divisão de trabalho, assumindo o trabalho escolar, que não pode ser separado do trabalho na sociedade em geral (QVORTRUP, 2011a, p.205).

A segunda, porque sua presença "influencia fortemente os planos e projetos não só dos pais, mas também do mundo social e econômico" (Id.).

A nova concepção sociológica considera as crianças como participantes de uma rede de relações que vai além da família e da escola ou creche. Como sujeitos sociais, elas são capazes de produzir mudanças nos sistemas nos quais estão inseridas, ou seja, as forças políticas, sociais e econômicas influenciam suas vidas ao mesmo tempo em que as crianças influenciam o cenário social, político e cultural. Nesse sentido, a infância é formada por sujeitos ativos e competentes, com características diferentes dos adultos. As crianças pertencem a diferentes classes sociais, ao sexo masculino ou feminino, a um espaço geográfico onde residem, à cultura de origem e a uma etnia, em outras palavras, são crianças concretas e contextualizadas, são membros da sociedade, atuam nas famílias, nas escolas, nas creches e em outros espaços, fazem parte do mundo, o incorporam e, ao mesmo tempo, o influenciam e criam significados a partir dele.

Para Qvortrup (1991), utilizar as crianças como unidade de observação principal define a categoria geracional infância na estrutura social, o que "implica que, ao procurar as principais características da infância como construção social, as diferenças entre as crianças serão menos consideradas do que aquilo que é comum entre as crianças" (p.17). Além dessa implicação metodológica, ao tomar a infância como unidade de observação, a Sociologia da Infância dá às crianças um lugar no quadro mais amplo das ciências sociais. 


\subsection{Atores, agentes e culturas infantis ${ }^{20}$}

Desde a década de 1990, têm sido apresentados novos estudos sobre as crianças, que partem do paradigma de que a infância é uma construção social. Essa formulação

fornece um quadro interpretativo para contextualizar os primeiros anos de vida humana. Infância, como distinta da imaturidade biológica, não é nem natural nem uma característica universal dos grupos humanos, mas aparece como um componente específico estrutural e cultural de muitas sociedades. (JAMES; PROUT, 1997, p.8)

O caráter estrutural exige a ideia de permanência da infância, ou seja, a infância não se caracteriza como tempo de passagem, mas como uma categoria permanente na estrutura social. De acordo com Qvortrup,

um conceito estrutural [...] visa caracterizar a infância como parte de uma dada arquitetura social, e por isso é também útil para comparar a infância com outros grupos em uma dada sociedade, bem como com a infância em diferentes nações e períodos históricos (2002, p.48).

A infância como categoria estrutural, ao mesmo tempo em que configura um espaço no qual as crianças vivem suas vidas, vai se modificando assim como se modificam as outras categorias, submetidas às mesmas variáveis históricas, políticas, econômicas, por exemplo. Neste sentido, a infância é simultaneamente um lugar de mudança e "uma forma estrutural permanente na qual todas as crianças vivem sua infância pessoal. [...] Quando a criança cresce e torna-se adulto, sua infância termina, mas a infância como forma não vai embora e estará lá para receber novas gerações de crianças" (QVORTRUP, 2009a, p.26), o que, segundo o sociólogo, torna possível combinar a utilização de infância, no singular, e de infâncias, no plural.

20 NASCIMENTO, M.L.B.P.N. Crianças pequenas e a produção de culturas In: GOBBI, Marcia A.; NASCIMENTO, M.L.B.P.N. (Orgs.). Educação e diversidade cultural: desafios para os estudos da infância e da formação docente. 1ed. Araraquara - SP: Junqueira\&Marin Editores, 2012b, p. 68-89 
Essa perspectiva permite (1) considerar as crianças como seres históricos, sociais, que estabelecem relações com outras crianças e com adultos, como pessoas participantes da sociedade, ainda que de forma limitada, que são influenciadas por eventos políticos, econômicos, tecnológicos, dentre outros, e cujas qualidades - recursos, criatividade, inventividade - são utilizadas nessas relações sociais; (2) reconhecer as crianças como pessoas ativas na "construção e determinação de suas próprias vidas sociais, das vidas daqueles que as cercam e das sociedades nas quais elas vivem" (JAMES; PROUT, 1997, p.8). Em outras palavras, significa compreender as crianças como coconstrutoras da sociedade (QVORTRUP, 1993; DAHLBERG; MOSS, PENCE, 2003; CHRISTENSEN; PROUT, 2005), como atores sociais. Diz Sarmento (2004) que "as crianças, todas as crianças, transportam o peso da sociedade que os adultos Ihes legam, mas fazendo-o com a leveza da renovação e o sentido de que tudo é de novo possível." (p.10)

Parece oportuno esclarecer que o conceito de criança como ator social é diferente da concepção de criança ativa. Esta última tem como base a compreensão de que o pensamento infantil se caracteriza por atividade particularista, ou seja, "a criança dedica-se à réplica repetitiva e muito concreta de estados objectais, encontrando-se dominada por estruturas objectivas e habitando um universo material" (JENKS, 2002, p.208). Isto significa que age de maneira direta sobre o que está próximo, sem distanciamento ou reflexão, uma vez que a ação é racionalmente regulada pela lógica do desenvolvimento. Ou, nas palavras de Corsaro (2005/2007), “o foco [está] no desenvolvimento individual humano e de como a criança internaliza as competências adultas e o conhecimento" (p.1). Concebida assim, a ação da criança é individual, sendo desconsiderados tanto o fato de que ela faz parte de um meio cultural quanto "as mudanças no seu grau ou intensidade de membro e participação ao longo do tempo" 
(CORSARO, 2005/2007, p.1, grifo no original). Dessa forma, a imagem da criança ativa está próxima da apropriação do conhecimento cognitivo, se distancia dos mundos sociais, e não pode ser confundida com o conceito de ator social, cujas ações geram/repercutem contextos sociais.

O reconhecimento das crianças como atores sociais, que, por meio das relações estabelecidas com adultos e com outras crianças, constroem sua participação social enquadra o contexto teórico que sustenta o conceito de agência. Mayall diz que "é claro que, mesmo sem pesquisa formal, as crianças são atores sociais: elas fazem parte das relações familiares; elas expressam seus desejos, demonstram fortes ligações, ciúmes e prazer, buscam justiça" (apud JAMES, 2009, p. 40-41), ou seja, estabelecem relações sociais. Agência, entretanto, define a amplitude dessas relações.

O que é agência? Os sociólogos Emirbayer e Mishe, em artigo publicado em 1998, definem como

compromisso construído temporalmente por atores de diferentes contextos estruturais - os quais, através da interação de hábito, imaginação e julgamento, reproduzem e transformam as estruturas em respostas interativas aos problemas postos por situações históricas em mudança (p.970, grifo no original)

Nesse sentido, destacam a repetição, a projetividade e a avaliação prática como elementos constitutivos da agência humana, que correspondem, respectivamente, a ações orientadas pelo passado, pelo futuro e pelo presente.

Sewell Jr. (1992) afirma que "ser agente significa ser capaz de exercer algum grau de controle sobre as relações sociais nas quais se está envolvido, o que, por sua vez, implica na habilidade de transformar essas relações sociais de alguma forma" (p.20). Diz ainda que a capacidade para a agência é inerente aos seres humanos, mesmo que assuma 
diferentes formas e seja cultural e historicamente determinada, o que indica que "todos os membros da sociedade exercitam, em alguma medida, a agência na condução de suas vidas cotidianas" (1992, p.20).

O conceito é importante para a compreensão da dinâmica das relações sociais como um todo, incluindo aquelas estabelecidas por e entre as crianças. Corsaro (2005/2007) relata que a aplicação da teoria de Emirbayer e Mishe, em casos concretos, ajuda a romper com as abordagens individualistas: "a natureza relacional e coletiva da agência, tende a suplantar o foco no actor individual" (p.3). Dessa forma, os aspectos cognitivos perdem a prioridade, ou seja, a agência proporciona um olhar sobre as "crianças como pessoas dignas de estudo, por direito próprio e não apenas como recipientes de ensino de adultos" (JAMES, 2009, p.34).

James localiza a origem desses estudos nas pesquisas realizadas nos anos de 1970, quando psicólogos começaram a reconhecer o trabalho de Vygotsky, o qual aponta as interações sociais entre as crianças e entre crianças e adultos como elemento crucial do desenvolvimento, além de reconhecer o papel da cultura na qual as crianças estão inseridas desde o nascimento. Na mesma época, sociólogos começaram a abandonar os preceitos durkheimianos ou parsonianos de socialização, que a entendiam como transmissão de valores, crenças e normas da sociedade à criança, considerando que ela as absorveria passivamente. Dessa forma, começaram a apontar o papel ativo das crianças neste processo.

O trabalho de Hardman (1973/2001) é citado por James como contribuição para a elaboração do novo paradigma, a partir da defesa de que as crianças poderiam "desenvolver uma autorregulação, um mundo autônomo, que não reflete, 
necessariamente, o desenvolvimento precoce da cultura adulta" (p.87), assim como o de Giddens (1979), que afirma que "cada ação que contribui para a reprodução de uma estrutura é também uma ação de produção, assim como é possível iniciar mudanças para alterar a estrutura, ao mesmo tempo em que a reproduzimos" (p.69). Estrutura e agência são conceitos complementares nos estudos da infância, pois

\begin{abstract}
Conceber a infância como uma unidade na estrutura social torna possível distinguir o desenvolvimento individual das crianças a partir da história cultural e histórica da infância. A infância como uma forma estrutural funciona como um quadro em que as crianças levam suas vidas.

Agência constitui uma competência individual das crianças, e não um sinal de sua subordinação em relação aos adultos. Como agentes, as crianças dão sua própria contribuição para a reprodução social e cultural. (QVORTRUP, CORSARO, HONIG, 2009, p.7)
\end{abstract}

Mayall, em 2002, distingue o ator social - alguém que age socialmente - do agente alguém que age socialmente e, ao fazê-lo, contribui para ampliar os processos de reprodução social e cultural. Retomando Sewell Jr. (1992), os agentes transformam as relações sociais de alguma forma, por meio da interação entre hábito, imaginação e julgamento (EMIRBAYER; MISHE, 1998). Nesse sentido, estudar as crianças como agentes é avançar em relação ao reconhecimento de sua atuação como protagonistas de suas próprias vidas, compreendendo-as como participantes ativas das vidas das pessoas que as rodeiam, nas sociedades nas quais vivem, que constroem relacionamentos e culturas inspiradas nos mundos sociais adultos.

Um dos pioneiros nos estudos sobre agência infantil é William Corsaro, que vem pesquisando crianças pequenas desde os anos de 1970, tendo realizado investigações nos Estados Unidos e na Itália. A partir dessas pesquisas, realizadas em creches e préescolas, de diferentes grupos sociais, envolvendo meninos e meninas, desenvolveu dois 
conceitos importantes para a área: reprodução interpretativa e culturas (de pares) infantis.

Sobre o primeiro conceito, Corsaro esclarece que interpretativo tem o significado de aspectos criativos e inovadores desenvolvidos pelas crianças em sua participação social; “o termo reprodução toma a ideia de que as crianças não estão simplesmente internalizando a sociedade e a cultura, mas que estão ativamente contribuindo para produção e mudança cultural" (1997, p.18, grifo no original). Acrescenta que "o termo também implica que as crianças são, pela sua própria participação na sociedade, condicionadas pela estrutura social existente e pela reprodução da sociedade" (1997, p.18).

As culturas de pares infantis são definidas como "um arranjo estável de atividades ou rotinas, artefatos, valores e interesses que as crianças produzem e compartilham em interação com os pares" (CORSARO; EDER, 1990; CORSARO, 1997, p.95). Corsaro considera que "características importantes das culturas de pares surgem e se desenvolvem como resultado das tentativas das crianças de atribuir algum sentido, e até certo ponto resistir, ao mundo adulto" (1997, p.115). Segundo ele, da interpretação dos sistemas culturais adultos, as crianças retiram elementos para a interação com outras crianças, ao mesmo tempo em que os aspectos da cultura de pares afetam a maneira como interagem com os adultos. Dito de outra maneira, a apropriação provoca a reinvenção da cultura, inter-relacionando os mundos sociais/culturais infantis e adultos. Isto é possível a partir do coletivo, da atividade em comum, na qual as crianças negociam, partilham e criam culturas com outras crianças e com os adultos. 
Corsaro $(2005 / 2007,2009)$ destaca ainda a importância da brincadeira para que se reconheça a agência coletiva das crianças. Aponta que o jogo de fantasia se constitui na própria interação social, num contexto implícito e improvisado que depende de recursos complexos, como, por exemplo, o uso de soluções paralinguísticas (voz, tom, entonação), manipulação orquestrada de objetos, descrição verbal das ações, repetição do discurso (2005/2007, p.7). Afirma também que as dramatizações de papéis, baseadas em modelos adultos, por um lado, "se referem primariamente a status, poder e controle", numa projeção do futuro, e, por outro, "permitem que a criança faça experiências sobre como diferentes tipos de pessoas da sociedade agem e se relacionam entre si" (2009, p.34).

A contribuição dos estudos sobre a agência das crianças, além de reconhecê-las como sujeitos e compreender a produção das culturas infantis, permite a captura de concepções, valores e rotinas dos adultos em relação à infância, ou seja, "a criança não é imaginada senão em relação a uma concepção de adulto, mas também é impossível criar uma noção precisa da adultez e da sociedade adulta sem primeiro tomar em consideração a criança." (JENKS, 2002, p.187). Está presente uma relação de reciprocidade, de interdependência entre as gerações.

Ferreira (2004) realizou pesquisa com crianças de um jardim de infância português, que acompanhou por nove meses, na qual apresenta normas e regras sociais construídas, a partir dos mundos sociais adultos, nas relações que as crianças de quatro anos estabelecem no grupo. No estudo, destaca que não há uma forma única e abstrata de agência, mas que as crianças assumem diversos papéis sociais, que as revelam como "actores sociais multifacetados, quer na ocupação, manutenção ou subversão de 
determinadas posições sociais, quer na mobilização de diferentes modos de acção quando lidam com os constrangimentos com que se deparam ou exploram as suas possibilidades" (p.387, grifo no original). Do ponto de vista das regularidades da experiência social das crianças no cotidiano das culturas de pares, destaca a reprodução interpretativa do mundo adulto, os processos de negociação, as estratégias de afirmação de poder, dentre outras. O estudo evidencia a capacidade de produção simbólica e a constituição das representações e crenças em sistemas organizados, ou seja, em culturas (SARMENTO, 1997).

\section{3 "Marginalidade e voz": notícias sobre a Sociologia da Infância como campo de pesquisa em diferentes países ${ }^{21}$}

A Sociologia da Infância é um campo que vem se delineando desde os anos 80 e "com um atraso de quase um século, em comparação a psicólogos, psiquiatras, pedagogos etc., os sociólogos da infância reuniram-se pela primeira vez em 1990, no Congresso Mundial de Sociologia" (Qvortrup, 1995, 2002), sob os auspícios da Associação Internacional de Sociologia (ISA). Em 1998, a seção de Sociologia da Infância tornou-se Comitê de Pesquisa (Research Comitee - RC53). Entre 1988 e 1998, Jens Qvortrup a presidiu.

Sete anos depois, em 2005, o Comitê de Pesquisa em Sociologia da Infância (RC53) realizou uma reunião em Wuppertal, na Alemanha, com o objetivo de esboçar um "estado da arte" da Sociologia da Infância, a partir de levantamento das pesquisas realizadas em diferentes países da Europa, nos Estados Unidos, na Austrália e no Brasil.

\footnotetext{
${ }^{21}$ Texto escrito em 2010, jamais publicado na íntegra.
} 
A partir de duas questões "por que a Sociologia da Infância em muitos países permanece à margem como campo da Sociologia?" e "essa 'marginalidade' está relacionada à situação marginal da infância nas sociedades contemporâneas?", os participantes tiveram oportunidade de discutir, ao longo de três dias, as diferentes interpretações, propostas metodológicas, perspectivas políticas e acadêmicas da Sociologia da Infância no mundo.

Este artigo pretende reportar os relatos apresentados na reunião, a partir dos resumos dos levantamentos realizados nos diferentes países que compareceram ao encontro.

\subsubsection{Primeira avaliação}

O documento produzido pelo RC53 para a reunião afirma que, depois de cerca de vinte anos de pesquisa teórica e de desenvolvimento de metodologias, é possível constatar que a Sociologia da Infância cresceu em alguns países, tendo envolvido pesquisadores e sustentado teórica e metodologicamente várias pesquisas. Atualmente, há inclusive jornais e revistas específicas do campo, tanto em âmbito nacional quanto internacional.

Entretanto, questiona uma certa restrição acadêmica ao reconhecimento da Sociologia da Infância como subcampo da Sociologia. Nesse sentido, à exceção de alguns países do norte europeu, a Sociologia da Infância não aparece como linha de pesquisa nas universidades e os poucos trabalhos acadêmicos, publicados nos principais jornais especializados, abordam principalmente os processos de socialização ou de instrução, o que leva a concluir que a infância tem ainda pouco espaço no debate teórico sociológico.

Segundo o documento, há clara conexão entre a avaliação da participação social das crianças e a institucionalização da pesquisa na Sociologia da Infância, o que parece 
significar que, em países nos quais a infância permanece mais envolvida nas relações de ordem privada - familiares e de parentesco -, o desenvolvimento da Sociologia da Infância é mais recente, indicando que há correspondência entre a posição das crianças no discurso público e a pesquisa na Sociologia da Infância. Neste sentido, os debates internacionais sobre os direitos da criança, em especial a Convenção dos Direitos da Criança, e as decisões políticas associadas a eles, deram recentemente uma amplitude maior à pesquisa na área.

\subsubsection{A situação da infância e o desenvolvimento da Sociologia da Infância: os relatos (country reports)}

A situação da infância nos diferentes países, mais particularmente o processo de passagem de um estado de "marginalidade" para uma situação de protagonismo, parece ser o marco do surgimento da Sociologia da Infância como base teórica e metodológica de pesquisa. Entretanto, em alguns dos países representados, houve maior desenvolvimento do campo, em paralelo - ou como consequência - de um amplo debate envolvendo governos, sociedade civil e universidade.

No Reino Unido22, por exemplo, a publicação do texto "Constructing and Reconstructing Childhood", por Allison James e Alan Prout, em 1990, foi o marco do desenvolvimento do debate teórico que ajustou a Sociologia à infância. Em paralelo, a política nacional britânica e as mudanças legais abriram espaço para o reconhecimento das crianças como sujeitos de seus próprios direitos, ainda que de modo limitado. Naquele país, a Sociologia da Infância está presente formalmente nas instituições acadêmicas, cujas

\footnotetext{
${ }^{22}$ Apresentação de Jo Moran-Ellis, do Departamento de Sociologia da Universidade de Surrey, UK.
} 
pesquisas versam sobre crianças como agentes sociais, sobre o conceito de direitos da criança, e sobre os espaços para que as vozes das crianças sejam ouvidas, e são acompanhadas por debates governamentais e das ONGs. O campo está estabelecido e tem sido ampliado nos espaços acadêmicos e em alguns espaços políticos.

Na Itália ${ }^{23}$, os grupos de pesquisa das universidades de Modena e Urbino seguem as novas teorias da Sociologia da Infância, e consideram a criança como ator social, estudando sua participação ativa nos processos sociais, principalmente pela abordagem cultural. Os grupos de pesquisa das universidades de Milão e Piemonte Oriental têm trabalhado com uma abordagem mista de Psicologia e Sociologia para analisar as representações sociais das crianças sobre comportamentos, com particular referência à diversidade cultural. Grupos das universidades de Bolonha e Padova têm trabalhado com as relações entre crianças imigrantes e o sistema legal. Os pesquisadores da universidade de Torino estão trabalhando com a percepção do tempo pelas crianças, sem clara orientação teórica. Alguns pesquisadores têm trabalhado com os efeitos da mídia sobre a infância.

Em paralelo, têm sido realizados debates sobre a conexão entre educação e participação das crianças, promovidos pelo Governo Central e pelas administrações locais, que envolvem professores, pais e políticos, e acontecem geralmente nos espaços escolares. São debatidos temas como a imigração e seu impacto no sistema escolar, a organização social da vida das crianças e o consumo de massa veiculado pela mídia. Ainda não houve tentativa de estabelecer um conhecimento mais geral sobre a condição da infância na Itália.

\footnotetext{
${ }^{23}$ Por Claudio Baraldi, da Universidade de Modena e Reggio Emilia.
} 
Na Alemanha ${ }^{24}$, desde os anos 80 , as mudanças sociais e políticas relacionadas à infância foram acompanhadas pela pesquisa. Foram cinco pontos principais que levaram os sociólogos a estudar aspectos da vida das crianças e a posição da infância:

- a ruptura política e social após a Primeira e a Segunda Guerras Mundiais, o que fez emergir a questão de geração;

- a mudança de um regime autoritário para um democrático, no final dos anos 60, o que fez emergir questões sobre o controle e intervenção sobre as crianças;

- as mudanças na economia e na vida urbana desde a década de 60, que desencadearam questões sobre socialização, separação entre gerações e sobre as estruturas de poder;

- a erosão do papel masculino como provedor do lar, o que aumentou as questões sobre a ordem geracional no nível da estrutura social;

- as mudanças de uma sociedade moderna para uma pós-moderna, o que desencadeou questões sobre as fronteiras entre as gerações e sobre a individualização e a formação da identidade nas vidas das crianças.

Desde o começo dos anos 90, a Sociologia da Infância tem sido utilizada, seu desenvolvimento científico tornou-se visível por meio de publicações e por sua institucionalização na Associação Alemã de Sociologia.

$\mathrm{Na}$ Holanda ${ }^{25}$, as transformações na vida familiar e o estímulo para a entrada das mulheres no mercado de trabalho desencadearam a implementação de facilidades para

\footnotetext{
${ }^{24}$ Apresentação de Helga Zeiher, do Instituto Max-Plank de Berlim.

25 Por Rineke van Daalen, do Departamento de Sociologia e Antropologia da Universidade de Amsterdã.
} 
o cuidado das crianças, mas não foram acompanhadas por debates sobre as mudanças no cotidiano das crianças ou sobre as novas relações entre família e Estado. Temas como a percepção das crianças sobre os efeitos das mudanças sociais, a ampliação das relações sociais, e as relações de poder entre crianças e adultos precisam de mais pesquisa. As crianças são cada vez mais vistas como sujeitos, com sua própria voz, mas, ao mesmo tempo, tornam-se mais vulneráveis como indivíduos. Como parte de seu processo de emancipação, as crianças são vistas como minoria. Os estudos sobre a infância têm como referência pesquisas norte-americanas.

Na Romênia ${ }^{26}$, as crianças veem-se numa situação contraditória: por um lado, têm sido alvo de grande interesse social, e, por outro, são mantidas distantes de questões relevantes do mundo adulto. Embora recentemente as leis e as pesquisas as coloquem como atores sociais, permanecem problematizadas a partir da perspectiva do adulto. Falta conhecimento mais aprofundado sobre a infância, assim como de alguns efeitos da nova ideologia dos direitos da criança, ou seja, a infância vista como oposição aos adultos parece torná-los ainda mais poderosos nas relações sociais estabelecidas com as crianças.

Nos EUA ${ }^{27}$, os estudos sobre a infância tornaram-se disciplina nas universidades e há amplo debate sobre o tema, provocando a pesquisa sociológica do ponto de vista teórico e metodológico. Há algumas publicações e o suporte das agências financiadoras para as pesquisas na área.

\footnotetext{
${ }^{26}$ Apresentação de Elisabeta Stanciulescu, da Babes-Bolyai University Cluj-Napoca.

27 Por Loretta Bass, do Departamento de Sociologia da Universidade de Oklahoma.
} 
Nos países de língua francesa ${ }^{28}$, a Sociologia da Infância foi desenvolvida de acordo com a concepção de criança como ator social. Os problemas relacionados à escola, à família e à mídia têm sido estudados a partir do novo status da infância, na modernidade. Cada um desses problemas deve ser visto em relação às estruturas institucionais da socialização pois parece indispensável levantar questões sobre as relações recíprocas e sobre a ação da criança, considerada agora como ator social. O debate teórico sobre o status das crianças como pessoas, algumas mudanças recentes na concepção de criança, assim como as realidades em que vivem, delinearam a necessidade de novas questões metodológicas e epistemológicas para o desenvolvimento da Sociologia da Infância. Um dos maiores obstáculos enfrentados parece ser a natureza antropológica, dos pontos de vista afetivo e moral, que envolve o tema infância. O sociólogo, mais do que nunca, confronta-se com a ambiguidade, o que implica no uso de métodos já conhecidos, por exemplo, a etnografia, mas indica a necessidade da criação de nova metodologia para renovar a Sociologia da Infância e afirmá-la como legítima, na perspectiva acadêmica.

No Brasil $^{29}$, a pesquisa das Ciências Sociais sobre a infância tem principalmente focalizado as crianças em situação de risco, em razão da enorme desigualdade social presente no país. A infância ${ }^{30}$ permanece como um aspecto nas investigações sobre urbanização, democratização, análises sobre pobreza e poder, não havendo ainda estudos sistemáticos para destacar o papel da infância na sociedade brasileira.

\footnotetext{
${ }^{28}$ Apresentação de Régine Sirota, da Universidade de Paris.

${ }^{29}$ Por Lúcia Rabello de Castro, da Universidade Federal do Rio de Janeiro.

${ }^{30} \mathrm{Em}$ relação ao Brasil, parece importante notar que foi criado um grupo na Sociedade Brasileira de Sociologia, denominado Sociologia da Infância e Juventude (GT26).
} 


\subsubsection{As pesquisas apresentadas}

As pesquisas foram organizadas em três grandes grupos: "Infância e Marginalidade problemas sociais, proteção à infância e políticas para a infância", "Crianças e os 'arranjos' da vida privada - divórcio, responsabilidade e participação familiar e doméstica" e "Políticas de infância e implicações para socialização política - participação na vida pública". O conjunto apresentado parece representar os principais temas que constituem a pesquisa na área da Sociologia da Infância, nos variados países presentes. No primeiro grupo ${ }^{31}$ foram apresentadas pesquisas sobre infâncias indígenas, na África do Sul e no Brasil; sobre as vozes infantis em meio à pobreza e à AIDS, na África do Sul; sobre as políticas públicas e a educação infantil, no Brasil; sobre as práticas nos jardins de infância, na Polônia; sobre a reforma dos direitos de proteção à infância, na Romênia; e sobre a infância de ex-prisioneiras de um centro de reabilitação feminino, em Israel.

O segundo grupo ${ }^{32}$ teve apresentação de pesquisas sobre as dimensões do valor da infância no Irã; sobre efeitos pós-divórcio, no Reino Unido; sobre as práticas democráticas, nos EUA; sobre o poder nas relações familiares, na Alemanha; sobre o uso do tempo e sobre as crianças e os procedimentos na separação dos pais, na Itália.

O terceiro grupo ${ }^{33}$ viu apresentados trabalhos sobre a reforma educacional e a desigualdade social na Noruega; sobre a percepção política das crianças belgas; sobre

\footnotetext{
${ }^{31}$ Participaram do grupo "Infância e marginalidade - problemas sociais, proteção à infância e políticas para a infância", os autores: Helen Penn, Ângela Nunes, Kammila Naidoo, Maria Letícia Nascimento, Katarzyna Gawlicz, Doina Balahur, Yael Maoz-Shai.

32 Compuseram o grupo 2, "Crianças e os "arranjos" da vida privada - divórcio, responsabilidade e participação familiar e doméstica", respectivamente, Mohammad Taghi Sheyki, Bren Neale, Andrew M. Koch, Beatrice Hungerland e Anne Wihstutz, Carmen Beloni, Roberta Bosisio.

${ }^{33}$ No âmbito do tema "Políticas de infância e implicações para socialização política - participação na vida pública", os autores, em ordem, foram: Trond Solhaug; Philippe de Vries, Christ'I De Landtsheer, Wannes Heirman e Kim Boudiny; Agnes Raczkevi; Mihaly Csákó; Armin Nolzen e Heinz Sünker; Ursula Winklhofer; Oleg Malanin; Teresa Hutchins; Daniel B. German e Caitlin Lally, Russell Farnen
} 
as relações entre as crianças e a mídia e sobre as relações entre educação e democracia, na Hungria; sobre as "crianças da Resistência" contra o regime nazista e sobre modelos de participação da infância em diferentes instituições, na Alemanha; sobre crianças abandonadas, na Rússia; sobre o espaço ocupado pela infância no processo de tomada de decisões, na Austrália; sobre os efeitos da TV e da Internet sobre a infância, nos EUA; e sobre a socialização política e a educação das crianças nos EUA e no Canadá.

Além dos três grupos, houve espaço para a apresentação e discussão das novas abordagens $^{34}$ na área e seu potencial para a Sociologia da Infância. Os trabalhos referiram-se à posição da infância frente aos processos de socialização e participação social e a busca das implicações metodológicas e epistemológicas desse tipo de investigação (Suíça); aos efeitos do estado de bem-estar social na pesquisa sobre a infância e aos potenciais de integração entre a pesquisa sobre família e sobre infância (Alemanha); e sobre a utilização da História da Infância e da Educação como referência para estudos sobre a infância (Dinamarca).

\subsubsection{Conclusões}

A reunião proposta pelo RC53 favoreceu a apresentação da diversidade de pesquisas de diversos países, recolhendo os trabalhos dispersos, isolados, sem diálogo, o que permitiu ver um amplo movimento de pesquisa internacional em construção, permeado por diferentes dificuldades.

\footnotetext{
${ }^{34}$ As novas abordagens foram apresentadas por Jean Paul Payet, da Universidade de Genebra; Johanna Mierendorff, da Martin-Luther-Universität Halle/Wittenberg; Andréas Lande, do Deutsches Jurgendinstitut München; e Ning de Coninck-Smith, da Danish University of Education
} 
A discussão colocada apontou para a necessidade de utilização de procedimentos metodológicos que tragam à tona não somente a voz da criança, procedimento necessário para tirá-la de sua invisibilidade estatística, mas também de abordagens que possibilitem uma complementaridade interna face à especificidade do objeto de investigação, de maneira que o trabalho empírico faça avançar a teoria.

A hipótese original do RC53 estava correta: o desenvolvimento do campo da Sociologia da Infância acontece em paralelo à posição que a infância ocupa nos diferentes países. Além disso, parece necessário "construir convergências e romper fronteiras de territórios divididos no interior da Sociologia para construir um campo sólido, que faça possível compreender as lógicas da criança e a evolução de seu estatuto" (Sirota, 2005).

\subsection{Diferenças e divergências}

O desenvolvimento do campo da Sociologia da Infância, pelas diferentes abordagens utilizadas na produção de pesquisas, acabou provocando diversas possibilidades de organização desta produção. Em 1994, Frønes nomeou dimensões as categorias encontradas dentre as produções analisadas no projeto Childhood as a Social Phenomenon, a saber: (a) relações entre as gerações, (b) relações entre as crianças, (c) organizações institucionais da infância e (d) infância como grupo de idade. Em 1998, o artigo Montandon, publicado no Brasil em 2001, vai recuperar as categorias de Frønes e acrescentar as correntes (a) interacionista, (b) de construção social da infância, (c) de desconstrução de narrativas sobre a infância e (d) da socialização. James, Jenks e Prout, no mesmo ano, vão apresentar quatro imagens de criança, na perspectiva sociológica:

(a) criança socialmente construída, (b) criança tribal, (c) criança como grupo minoritário 
e (d) criança como estrutura social. Qvortrup, em 1999, organiza as pesquisas da Sociologia da Infância em dois pilares: a abordagem estrutural e a abordagem da agência. Mayall (2002) organiza as pesquisas em três linhas: (a) sociologia das crianças, (b) sociologia da infância desconstrutiva e (c) sociologia da infância estrutural. Em 2006, Gaitán Muñoz estabelece três enfoques distintos: estrutural, construcionista e relacional. Sarmento, em artigo de 2008, defende três correntes: estudos estruturais, estudos interpretativos e estudos de intervenção.

As variadas organizações não terão aqui um aprofundamento maior ${ }^{35}$, mas foram apresentadas para evidenciar que o campo da Sociologia da Infância é mais amplo do que o reconhecimento da agência das crianças e que a infância é um fenômeno social complexo, e, neste sentido, uma única perspectiva epistemológica ou disciplina não dará conta de seu estudo (JAMES; JAMES, 2008). Este quadro inspirou a pesquisa Relações entre a pesquisa nos estudos da infância e os contextos nos quais se insere, cujo objetivo era compreender as diferentes configurações em que a pesquisa da infância é realizada e que constitui a base desta tese.

Cabe lembrar que o campo dos estudos da infância apresenta predominante produção de pesquisa em língua inglesa, mas há produção significativa em língua francesa. Em relação à língua portuguesa, com referência a pesquisadores brasileiros além dos portugueses, esta começa a ser reconhecida, como indicam os recentes artigos de Sirota (2012), que destaca que "se traduz e publica tanto textos de origem francófona e anglófona, combinando referências às três regiões linguísticas" (p.10) e Mayall (2013), que comenta que "redes internacionais têm sido estabelecidas [por Portugal],

\footnotetext{
${ }^{35}$ Ver Breda, 2010, 2015.
} 
especialmente com o Brasil, onde algumas publicações em português começam a aparecer." (p.33)

\subsubsection{Pontos de vista, divergências e diferenças no campo da Sociologia da Infância anglófona}

A leitura de publicações do campo dos estudos da infância, notadamente em língua inglesa ${ }^{36}$, permite encontrar diferentes pontos de vista sobre a infância e sobre os estudos da infância. Podemos denominá-las discussões internas ou debates epistemológicos da área.

Lee (1998), por exemplo, questiona o estatuto teórico da então nova Sociologia da Infância. Diz ele que a Sociologia da Infância propõe o estudo das crianças em seu próprio direito, e que, para isso, os sociólogos foram obrigados a atribuir agência às crianças. Em suas palavras,

Essa concepção agêntica de infância, estrategicamente necessária para a formação da sociologia da infância como campo de pesquisa distinto, invoca a decisão de que a agência causal ou interpretativa repousa nas crianças como sua propriedade ou posse. (p.459)

Segundo Lee, tanto James e Prout (1990) quanto Qvortrup (1994) tiveram que tomar uma decisão para "Tratar as crianças como seres [beings] e evitar cumplicidade com hierarquias com base na idade e, ao mesmo tempo, assegurar que a própria pesquisa permita uma reflexão completa e sem distorções das atividades, culturas e vozes das crianças." (p.462) O pesquisador apresenta exemplos de agência como dependência e

\footnotetext{
${ }^{36}$ Embora possam ser encontradas várias publicações, nesta tese a referência serão principalmente os periódicos Childhood; Children\&Society; Children's Geographies, embora outros periódicos possam se referidos.
} 
afirma que "agência é um elemento da independência que emerge de uma dependência fundamental" (p.472), refutando assim as teses da Sociologia da Infância. E conclui apontando que a Sociologia da Infância se afirmou como subdisciplina ao forjar as crianças como seres (beings), estratégia necessária para a inclusão das crianças na Sociologia, pois a teoria sociológica privilegia a maturidade e a completude. No entanto, a possibilidade de uma sociologia imatura pode compor uma outra "ética do movimento" (p.477)

Prout (2010, 2011) desde 2005 levanta questões sobre a abrangência e a consistência da Sociologia da Infância que, segundo ele, estão apoiadas na Sociologia moderna que, argumenta, é marcada pelas dicotomias que dividiram o mundo social, embora a desorganização, os fenômenos complexos ou híbridos ou ambivalentes sejam características dessas sociedades. Neste sentido, a separação das ocorrências não se mostra adequada para compreender a vida social contemporânea. Refletindo sobre a Sociologia da Infância, diz que:

Por exemplo, dois elementos-chave na Sociologia da Infância, a ação das crianças e a ideia de infância como uma estrutura social, vieram diretamente da Sociologia moderna, em uma forma mais ou menos idêntica. [...] Enquanto a Sociologia procurava metáforas para mobilidade, fluidez e complexidade, a Sociologia da Infância ia edificando a infância como uma estrutura. (2010, p.733)

Para Prout, as dicotomias se tornaram mutuamente exclusivas, deixando de considerar mediações e conexões entre as oposições, e, assim, "ocultando aspectos importantes sobre o modo como se constroem as infâncias contemporâneas" (p.738). E, dessa maneira, afirma que o discurso dualista limita o desenvolvimento do campo da Sociologia da Infância. Propõe, então, desenvolver e explorar novas ideias, que terão como foco o terceiro excluído, para incluí-lo. E completa: 
[as ideias] não deveriam de antemão inscrever um conjunto de dicotomias no campo, e sim observar a infância como um fenômeno complexo, não imediatamente redutível a um extremo ou outro de uma separação polarizada. [...] A abordagem que tenho em mente é similar à do autor italiano Norberto Bobbio, quando se refere ao "terceiro incluído": "ele tenta encontrar seu próprio espaço entre dois opostos e, embora se insira entre eles, não os elimina [...] eles deixam de ser duas totalidades mutuamente exclusivas, como as duas faces da mesma moeda, que não podem ser vistas ao mesmo tempo" (BOBBIO, 1996, p.7 apud PROUT, 2010, p.739)

Uma das discussões provocadas por esta posição refere-se à existência de várias infâncias, cada uma com seus pontos de referência particulares, que não podem ser plenamente compartilhados por outras infâncias. Segundo Nascimento (2011b), “A defesa de uma infância, a partir do que as crianças têm em comum, como categoria geracional, ou de várias infâncias, destacando particularidades, tornou-se uma polêmica discussão entre pesquisadores ${ }^{37 \prime \prime}$ (p.43).

Recente artigo de Tisdall e Punch (2012b), publicado em Children's Geographies, discute o quanto o paradigma da infância teve de repercussão nos últimos 20 anos, e busca destacar os desafios teóricos e aplicabilidade dos conceitos nos mundos majoritário e no minoritário. As autoras recuperam as críticas de Prout e Lee, do ponto de vista da teoria, e, em seguida, argumentam que algumas das normas globalizadas não se aplicam a grupos de crianças que tem outro tipo de experiência, como as crianças-soldados as crianças migrantes, as crianças com HIV ou AIDS, objetos e sujeitos de pesquisas, ou seja, que pesquisar a vida dessas crianças demanda um olhar para a complexidade posta nestas vidas. Questionam, então, o conceito de agência e referem

Por exemplo, os pesquisadores têm se esforçado para atribuir agência para crianças-soldados (Rosen 2007), prostituição infantil (Montgomery 2009) e crianças de rua (Hecht 1998), para oferecer uma alternativa para a imagem estereotipada de tais crianças e jovens

\footnotetext{
${ }^{37}$ Ver Qvortrup, 2010b e Prout, 2010, que argumentam sobre uma e outra posição.
} 
como vítimas indefesas. As limitações da agência das crianças e dos jovens nesses contextos restritos são certamente reconhecidas, mas talvez não suficientemente problematizadas. (p.255)

As autoras criticam ainda o universalismo da Convenção dos Direitos da Criança e concluem refletindo que

A pesquisa nos estudos da infância, particularmente no Reino Unido, está repleta de exemplos de crianças e jovens como agentes socialmente competentes, com pouco espaço para alternativas. [...]. Os principais aspectos da 'mudança de paradigma' (Holt e Holloway 2006) já estão bem estabelecidos: a escuta de crianças e jovens, crianças e jovens como atores sociais e sua participação na sociedade e na pesquisa. No entanto, ainda há espaço para criticar ou avançar em cada um deles (ver também James 2007, Tisdall 2012). Concentrarse nas perspectivas, agência e participação de crianças e jovens tampouco é suficiente; é necessária maior ênfase sobre os meandros, complexidades, tensões, ambiguidades e ambivalências das vidas das crianças e dos jovens nos contextos do mundo majoritário e minoritário. (p.259)

Um dos aspectos mais interessantes da diversidade de críticas é o reconhecimento de que há diferentes possibilidades de estudos da infância, ou, como diz Adrian James (2010), "os estudos da infância estão se aproximando de uma encruzilhada, chegando a um ponto, em sua história e desenvolvimento, em que as questões devem passar antes por como o campo é agora percebido e se há possibilidade um entendimento compartilhado do que foi anteriormente um projeto unificado" (p.485). A diversidade de posições justifica que vários pesquisadores tenham pensado em diferentes organizações do campo, como se expôs anteriormente. 


\section{Capítulo 2}

\section{Alguma informação sobre pesquisa em Sociologia da Infância no Brasil}

Esse capítulo não pretende esgotar o que se tem realizado de pesquisa na e sobre a sociologia da infância, mas pretende oferecer um panorama sobre o tema, acrescido, na sequencia, de breve discussão sobre a interface entre a educação infantil e a sociologia da infância.

Pode-se pensar na abordagem sociológica na pesquisa da infância por diferentes caminhos, que vão desde as clássicas - e as recentes - teorias sobre o processo de socialização ${ }^{38}$, passam por aspectos da vulnerabilidade social das crianças $^{39}$ - a mortalidade infantil, a fome, as crianças abrigadas ou as de rua -, atravessam a escola e as relações de poder e de classe ${ }^{40}$ instauradas, e constituem exemplos de estudos sobre a infância e seu desenvolvimento no Brasil. Um campo específico, porém, denominado Sociologia da Infância chegou entre nós no início dos anos 2000, quando foram publicados (1) os textos de Régine Sirota ${ }^{41}$ e Cléopâtre Montandon ${ }^{42}$, traduzidos para o português, no periódico Cadernos de Pesquisa; (2) dois artigos de Manuel Sarmento ${ }^{43}$, sociólogo português, nos periódicos Movimento, da UFF, e Psicologia Clínica, da PUC-RJ, e um capítulo do livro Em defesa da educação infantil, todos produzidos no Rio de

\footnotetext{
38 DURKHEIM, 1978; PARSONS, 1991; DUBAR, 2005; DUBET, 1994.

${ }^{39}$ ALVIM, M. R.; VALLADARES, L.,1988

${ }^{40}$ BOURDIEU, P.; PASSERON, J. C., 1975

${ }^{41}$ SIROTA, R., 2001.

${ }^{42}$ MONTANDON, C., 2001.

${ }^{43}$ SARMENTO, M., 2001a; 2001b; SARMENTO, M.; SILVA, R.; COSTA, S., 2000.
} 
Janeiro; (3) o artigo da pesquisadora brasileira Jucirema Quinteiro ${ }^{44}$ na edição especial Leituras sociológicas em educação do periódico Perspectiva, da UFSC.

O campo da Sociologia da Infância surgiu na Europa e nos Estados Unidos na década de 1980, quando Corsaro, 1979; Jenks, 1982; Qvortrup, 1987; Alanen, 1988, publicaram artigos pioneiros da área. Segundo Qvortrup (2015), a proposta do projeto Infância como um fenômeno social: Implicações para Políticas Sociais Futuras, realizado entre 1987 e 2004, concretizou os esforços dos pesquisadores da infância "para lançar o nosso novo campo em pé de igualdade com outros campos sociológicos" (p.5). Em 1990, James e Prout registraram o novo paradigma ${ }^{45}$ da infância, constituído pelas seguintes assertivas: a infância é uma construção social; as relações sociais das crianças, e suas culturas, devem ser estudadas em si mesmas; as crianças são e devem ser estudadas como atores na construção de sua vida social e da vida daqueles que as rodeiam (JAMES; PROUT, 1990, p.8-9). Entre a década de 1990 e as pesquisas atuais, a constituição do campo $^{46}$ foi forjada a partir de pesquisas e de debates acadêmicos, realizados em congressos internacionais e em encontros temáticos, cujos resultados podem ser encontrados em várias publicações, algumas delas traduzidas para o português.

A consideração da infância como uma categoria - permanente - na estrutura social (QVORTRUP, 1991) rompeu com a concepção de criança "em devir" (becoming) e voltou-se para o estudo do impacto das questões políticas, econômicas e sociais sobre crianças "e adultos submetidos à mesma ordem de problemas. Trata-se, então, de

\footnotetext{
${ }^{44}$ QUINTEIRO, 2002.

45 Uma apresentação mais completa do paradigma pode ser encontrada em Nascimento (2011b).

${ }^{46}$ Ver Mayall, 2013.
} 
estudar relações entre sujeitos (being) contemporâneos e não mais entre seres maduros e em devir" (NASCIMENTO, 2011b, p.40). Nas palavras de Qvortrup (2002),

um conceito estrutural [...] visa caracterizar a infância como parte de uma dada arquitetura social, e por isso é também útil para comparar a infância com outros grupos em uma dada sociedade, bem como com a infância em diferentes nações e períodos históricos (2002, p.48).

No Brasil, de acordo com pesquisa realizada por Castro \& Kosminsky ${ }^{47}$ (2010) sobre a contribuição das Ciências Sociais para a visibilidade da infância, os sociólogos têm realizado pesquisas principalmente com vistas a crianças em situação de risco, de abandono, crianças trabalhadoras, abusadas ou infratoras, ainda que, a partir da Constituição Federal de 1988 e do Estatuto da Criança e do Adolescente (ECA), de 1989, a "legislação teve a virtude de estabelecer a equivalência judicial de todas as crianças, descaracterizando, ao menos judicialmente, o status depreciativo de 'menores' atribuído às crianças pobres" (p.214). Em relação às publicações científicas, concluem que apontam para:

(1) importante interface entre educação e sociologia, na qual uma "sociologia da infância" está começando a emergir; (2) aumento do número de publicações nos subcampos recém-cunhados de "antropologia da infância" e "história da infância"; e (3) escassez de publicações em revistas de sociologia tradicionais (p. 222).

Sobre o primeiro ponto, recente investigação (NASCIMENTO et al, 2013) sobre grupos que pesquisam a infância a partir da Sociologia da Infância revela que a maioria destes grupos está no campo da Educação, ou seja, são predominantemente grupos de pesquisa em educação infantil que trabalham com conceitos e proposições da Sociologia

\footnotetext{
47 As pesquisadoras analisam a contribuição das Ciências Sociais para a visibilidade da infância, considerando períodos de tempo e localizando, em cada um deles, a predominância de diferentes preocupações com/sobre a infância: "problema social" entre os anos 1960 e 1980; a criança como ator cultural e sujeito de direitos nas décadas de 1990 e 2000.
} 
da Infância, vinculados, em sua maioria, a programas de pós-graduação em Educação. Por um lado, a investigação apoiada na concepção de crianças como atores no campo social tem promovido outro tipo de conhecimento sobre elas, ou seja, "verificou-se que as investigações e os estudos desenvolvidos pelos grupos selecionados inspiram-se, em sua maioria, na perspectiva da agência, no cotidiano das crianças pequenas e métodos etnográficos" (Id., p.142). Por outro, as discussões teóricas e metodológicas não focalizam exatamente o campo da Sociologia da Infância, e, como consequência, deixam de contribuir para a produção de novos conceitos e possibilidades metodológicas da área, ou de novas questões epistemológicas sobre a infância e seu estudo numa abordagem sociológica. Nas palavras de James (PIRES; NASCIMENTO, 2014),

precisamos mostrar o valor de trazer a perspectiva das crianças a respeito de outros assuntos para além do que diz respeito apenas às crianças. Nós não precisamos realmente saber mais sobre o que acontece no parquinho, porque nós já sabemos mais ou menos o acontece no parquinho. Mas precisamos compreender mais, por exemplo, o papel das crianças na economia familiar ou o aspecto político das crianças e da infância. (p.940)

\subsection{A interface entre Sociologia da Infância e Educação Infantil ${ }^{48}$}

O presente texto apresenta resultados parciais da pesquisa intitulada Infância $e$ Sociologia da Infância: entre a invisibilidade e a voz, realizada entre os anos de 2010 e 2012, que teve como objetivo principal conhecer a produção realizada por grupos de pesquisa sobre Sociologia da Infância no Brasil.

\footnotetext{
${ }^{48}$ Texto modificado do publicado nos Anais Eletronicos III GRUPECI. Aracaju - SE: Anais Eletronicos III GRUPECI, 2012. p. 24-38.
} 
Do ponto de vista da presença da Sociologia da Infância no Brasil e do papel que desempenha nos estudos sobre a infância no país, Castro e Kosminsky (2010) apontam que a pesquisa das Ciências Sociais sobre a infância, entre as décadas de 1960 e 1980, focalizou as crianças principalmente na estrutura da desigualdade social no Brasil. Ou seja, por um lado, foram realizadas pesquisas sobre "o menor", notadamente crianças pobres, em situação de risco ou nos limites da marginalidade, e, por outro, "o aluno", em pesquisas sobre e na escola. Destacam que "em ambos os casos, as crianças não eram vistas como sujeitos, mas objeto de proteção, cuidado e controle, vitimizadas ou não pelas circunstancias" (p.213).

Em relação à pequena infância, Campos e Haddad (1992), em análise sobre pesquisas publicadas nos Cadernos de Pesquisa, entre 1970 e 1990, constatam que, na década de 70, houve uma destacada preocupação com o desenvolvimento cognitivo das crianças na pré-escola, o que voltava a produção científica para a criação de propostas de intervenção na pré-escola, e, na creche, eram realizados estudos sobre a privação materna e as teorias de apego. Dessa forma, no campo da Educação Infantil, o "ofício de criança" se confundia com o "ofício de aluno" (SIROTA, 2001, p.15), pois, relacionado ao processo de socialização, num primeiro momento, indicava recepção passiva da cultura escolar por parte das crianças.

Os primeiros estudos sobre interação entre crianças em creches e pré-escolas, no Brasil, datam da década de 1980 (OLIVEIRA, 1988; CARVALHO; BERALDO, 1989; PEDROSA, 1989), sob a ótica da psicologia do desenvolvimento ou na linha sócio histórica. Nesta perspectiva, as crianças, suas interações e brincadeiras começam a se tornar visíveis, embora predominem os resultados obtidos pelo papel desempenhado na sala do grupo 
ao qual pertencem. Nos anos 1990 e a partir de 2000, segundo Castro e Kosminsky (2010), a pesquisa sobre a infância tomou outra direção, notadamente a partir da legislação (Constituição Federal de 1988 e Estatuto da Criança e do Adolescente - ECA de 1990), da presença de organizações internacionais (UNESCO, UNICEF, OIT) e organizações não governamentais internacionais, do interesse de antropólogos e historiadores, ampliando os horizontes da pesquisa sobre as crianças como sujeitos de direito. As pesquisadoras apontam que a Sociologia da Infância como campo de conhecimento ainda tem pouca abrangência, mesmo que esporadicamente sejam publicados artigos sobre pesquisas com esta abordagem teórico-metodológica.

Na área da Educação Infantil, verificam-se algumas publicações recentes (CRUZ, 2008; FARIA, 2007, 2008; GOUVEA; SARMENTO, 2008) nas quais se reconhece que as crianças tem sido pesquisadas nas interações e brincadeiras que estabelecem nas creches e escolas de educação infantil, mais particularmente nos grupos que frequentam, ou nas rotinas, nas quais o foco de observação tem sido principalmente as falas e ações entre as crianças, em detrimento das atividades propostas pela professora (ALMEIDA, 2009). Pode-se perceber que estas investigações têm como base teórico-metodológica a Sociologia da Infância.

A partir desse breve resgate histórico, cabe observar que a Sociologia da Infância no Brasil, diferentemente de outros países do hemisfério norte onde já há maiores delineamentos no interior do campo, encontra-se em fase de constituição de identidade e de fortalecimento e divulgação de concepções teórico-metodológicas. Pode-se afirmar também que o campo aparenta inserir-se na produção científica brasileira em forte interface com os estudos da educação infantil. Isto posto, considerou-se pertinente 
pesquisar atuais grupos de pesquisa brasileiros que utilizam a Sociologia da Infância como referência e/ou produzam conhecimento nesta área. Pretende-se aqui apresentar parte dos resultados encontrados no mapeamento dos grupos no Brasil, que trabalham com produções teóricas neste campo e destacar, sobretudo, como esta área vem se constituindo em relação contínua com a primeira etapa da Educação Básica (educação infantil/ educação de crianças de 0 a 5 anos) ${ }^{49}$.

\subsubsection{Primeiros achados}

Considerando os 23 grupos selecionados pela pesquisa e o levantamento das informações de identificação e de produção bibliográfica dos mesmos, observamos aproximações e distanciamentos que merecem ser destacados. Dos grupos selecionados, 16 estão situados na área da Educação. Quatro grupos estão na área da Psicologia e três, na Sociologia. Dentre os 16 que estão na Educação, seis utilizam "educação infantil" como parte do nome do grupo, e um deles, localizado na área da Sociologia, adotou "sociologia da infância" como parte de seu nome. Considerando os grupos que estão na Educação, onze trabalham com pesquisa na educação infantil como área predominante. Todos os que se encontram na Psicologia também o fazem.

Parece interessante destacar que são 15 os grupos que têm em sua produção teóricometodológica referências tanto na área da Sociologia da Infância quanto na da Educação Infantil. Destes, sete - quase a metade - foram criados entre 1991 e 1999. No país, consideramos que a inserção das discussões da Sociologia da Infância, enquanto campo constituído com tal nomenclatura, data do início dos anos 2000, com a publicação da

\footnotetext{
${ }^{49}$ O relatório da pesquisa pode ser encontrado em NASCIMENTO et al (2013).
} 
tradução de textos de Régine Sirota e Cléopâtre Montandon. Foi também no início dessa década (2002) que foi publicado artigo escrito por pesquisadora brasileira, Jucirema Quinteiro, que se referia explicitamente ao tema.

Na década de 1990, mais especificamente nos anos de fundação dos primeiros grupos e em seus períodos iniciais, a Sociologia da Infância ainda era um campo pouco conhecido no Brasil e ainda desconsiderado para os estudos e produções. Naquela época, o foco estava no estudo das crianças, das políticas e das instituições de educação infantil, realizado por meio de diferentes aportes teóricos. A fundação dos grupos aconteceu em seguida à promulgação da Constituição Federal de 1988, que afirmou os direitos das crianças desde seu nascimento, reconhecendo seu direito à educação em instituições como creches e pré-escolas, o que vai inaugurar um período de aprofundamento de reflexões sobre as crianças nos espaços educacionais em nosso país. Assim, os grupos de pesquisa, então fundados, têm significativo papel na história das teorias e das práticas educativas com as crianças pequenas no Brasil.

Nas últimas duas décadas, a produção sobre o tema infância no campo da educação no Brasil parece ter ampliado o seu campo de intervenções e, também, adquirido algum estatuto téoricometodológico. Os estudos sobre a infância como uma questão pública e não apenas privada começam a pipocar na produção acadêmica brasileira. Constata-se uma produção caracterizada por diversidade de temas, pautados por estudos empíricos e ausência de debates teóricos, voltados a problemas relativos à história social da infância, às péssimas condições de vida e existência de crianças e de suas famílias, ao profundo desrespeito por parte do Estado à criança como sujeito de direitos e, sobretudo, aos diversos aspectos e especificidades que envolvem a educação e a proteção da criança de zero a seis anos de idade. (QUINTEIRO, 2005, p.21, grifos nossos)

Com configurações estáveis e em constante produção teórica, é possível considerar que metade dos grupos existentes à época da realização da pesquisa, que tratam da 
Sociologia da Infância em seus estudos e produção, apropriaram-se de questões do campo e o incorporaram em suas reflexões sobre a primeira etapa da educação básica: a educação infantil.

A outra metade, oito grupos, fundados entre os anos de 2005 e 2008, nascem no desenvolvimento do campo, ao mesmo tempo em que os grupos mais antigos divulgavam sua produção ${ }^{50}$, provocando novas possibilidades de estudos das crianças no contexto educacional. Vale observar, ainda, que os novos grupos foram fundados após a publicação de literatura da área no país.

Em relação aos autores do campo mais presentes nas referências dos grupos, Manuel Sarmento, presente em 11 deles; William Corsaro, em 10 grupos e Régine Sirota, também em 10. A recorrência de citações da produção de Manuel Sarmento pode ser explicada pela sua origem, autor português, que escreve no idioma e recebe pesquisadores brasileiros em sua universidade, tendo vindo algumas vezes ao Brasil.

Corsaro e Sirota também ocupam lugar de destaque nas referências bibliográficas utilizadas pelos grupos. Essa posição pode ser compreendida quando se analisam os conceitos da Sociologia da Infância mais utilizados pelos grupos em interlocução com a educação infantil. Corsaro, em suas pesquisas com crianças pequenas, em pré-escolas e creches dos Estados Unidos e da Itália, aponta para a inadequação do conceito tradicional de socialização - processo dirigido do adulto para a criança - e propõe, em seu lugar, o de reprodução interpretativa - no qual as crianças criam e recriam as

\footnotetext{
${ }^{50}$ ROCHA, 1999, 2001; STRENZEL, 2000, por exemplo.
} 
questões e situações da vida social adulta - estabelecida entre crianças e adultos, mas também entre crianças e crianças.

Em seu livro Sociologia da Infância, de $1997^{51}$, e em outros textos, o sociólogo destaca as relações entre as crianças, apresentando e discutindo as culturas de pares e a agência, conceitos que vêm se somar à perspectiva da criança como sujeito de direitos, na direção da concepção de criança como ator social. A metodologia de pesquisa do sociólogo, à semelhança da proposta pelo paradigma de James e Prout (1990), é a etnografia, que se confirma como uma possibilidade metodológica dos estudos da infância. Corsaro veio ao Brasil em 2007, quando fez palestras e discussões com grupos interessados em seus estudos, e voltou ao país em 2011.

Sirota, por sua vez, além da presença marcante de seu texto de 2001, traz o acompanhamento das culturas estabelecidas entre adultos e crianças na simbologia dos aniversários, em texto traduzido e publicado em $2005^{52}$.

Dentre os autores nacionais, destacam-se Jucirema Quinteiro que, como já apontado, publicou artigos e apresentou comunicações ${ }^{53}$ utilizando a Sociologia da Infância; Ana Cristina Coll Delgado, ativa e produtiva pesquisadora da área, que organizou, como coautora, mais de uma coletânea de autores ${ }^{54}$, e que, desde 1999 , discute as crianças como atores sociais ${ }^{55}$; e Florestan Fernandes, que, em 1941, realizou estudo que

51. Tradução brasileira de 2011, pela Ed. Artmed.

52 SIROTA, 2005.

${ }^{53}$ QUINTEIRO, 2003.

${ }^{54}$ DELGADO, 2006; 2005, ambos em parceria com Fernanda Müller.

${ }^{55}$ DELGADO, 2003; 1999. 
culminou com a publicação do texto "As Trocinhas do Bom Retiro". Cada um desses autores aparece em quatro grupos.

Para finalizar, se é possível reconhecer que os conceitos desenvolvidos pelo campo da Sociologia da Infância vieram contribuir para o fortalecimento dos estudos da pequena infância, a partir do novo paradigma e, assim, de uma nova interpretação da infância, pode-se perguntar, entretanto, o que significa para estar, de certa forma, subordinada ao campo da educação. Levando-se em conta que os conceitos mais destacados nos grupos estudados parecem relacionados com o cotidiano das crianças pequenas, os métodos etnográficos e a agência adquirirem importância. Entretanto, o campo da Sociologia da Infância implica em outras alternativas metodológicas e em outros conceitos, como estrutura, por exemplo. Nessa linha, pode-se discutir um suposto desequilíbrio entre os dois campos. 


\section{Capítulo 3}

\section{As relações entre a pesquisa em Estudos da Infância e os contextos nos quais é realizada ${ }^{56}$}

O projeto que norteou esta pesquisa foi concebido a partir de questões relacionadas ao estabelecimento do campo da Sociologia da Infância no Brasil, no que se refere particularmente às informações obtidas por pesquisa realizada entre 2010 e 2012, que apontava a forte relação entre essa vertente da Sociologia e a Educação.

Um aspecto que considero importante apontar como elemento possibilitador da pesquisa foi o fato de ter estabelecido contato anteriormente com as universidades ${ }^{57}$ que pretendia visitar. Retomei cada contato pois considerei que os centros de pesquisa da infância localizados nestas universidades constituíam referência tanto em produção de teoria quanto na prática da interdisciplinaridade em seus estudos.

Para obter as informações necessárias para a pesquisa, em cada universidade seria entrevistado um grupo delimitado de pesquisadores, composto pelo diretor do centro de pesquisa, por um pesquisador com produção reconhecida no campo dos estudos da infância e por um pesquisador visitante. Estes centros - Centro de Investigação em Estudos da Criança (CIEC), em Braga, Portugal; Interdisciplinary Center Childhoods. Societies (IZKG), em Wuppertal, na Alemanha; Norwegian Centre for Child Research

\footnotetext{
${ }^{56}$ Relations between research in Childhood Studies and the contexts in which it operates. Processo FAPESP 2013/17087-1.

57 Uni-Wuppertal, na Alemanha (2005); Sheffield, na Inglaterra (2012); Minho, em Braga, Portugal (2004, 2009, 2012), por meio de participação em eventos e contato com pesquisadores. Em relação à Norwegian University of Science and Technology NTNU, em Trondheim, Noruega, por ocasião da vinda do Prof. Qvortrup, em 2010, foi estabelecido um acordo de cooperação com a FEUSP e, dessa maneira, também havia um contato anterior.
} 
(NOSEB), em Trondheim, Noruega; Centre for the Study of Childhood and Youth (CSCY), em Sheffield, Inglaterra - foram definidos como os lugares de sua realização.

O objetivo da pesquisa era analisar a relação entre a natureza da pesquisa sobre infância

e o contexto no qual é desenvolvida, considerando a produção de teoria e a interdisciplinaridade, com especial atenção para o papel da educação. Suas principais perguntas eram:

Quais são os princípios e as abordagens teórico-metodológicas estabelecidas em cada um desses centros?

Quais são as contribuições do diálogo entre as áreas, a partir do mesmo ponto de vista?

Como é que estudos produzidos nestes centros contribuíram para avanços, desafios ou contradições no campo?

Qual é o significado da diferença nas abordagens dos estudos da infância, do ponto de vista da investigação e da produção de conhecimento sobre as crianças / infância?

A pesquisa incluía uma universidade de base, pode-se dizer, onde teria oportunidade de apresentar e discutir os dados produzidos com interlocutores qualificados, dentre eles, a Profa. Dra. Jo Moran-Ellis, do campo da Sociologia da Infância, parceira na elaboração e desenvolvimento de pesquisa ${ }^{58}$ em 2013.

Assim, foi realizada em dois movimentos distintos e complementares. Um deles, realizado na Universidade de Sussex ${ }^{59}$, UK, envolveu o acesso à biblioteca física e à virtual, para levantamento e atualização de leituras, reuniões periódicas para discussão

\footnotetext{
${ }^{58}$ Developing a Sociology for Early Childhood: advances and challenges with particular reference to the role of institutions in young children's lives, projeto financiado pelo UGPN.

${ }^{59}$ Embora o projeto original previsse a University of Surrey como universidade base da pesquisa, a profa. Moran-Ellis transferiu-se para a University of Sussex em fevereiro de 2014, onde trabalha como professora de sociologia e como chefe do departamento de sociologia, condição que lhe permite trabalhar com a sociologia da infância em uma universidade onde há um centro de pesquisa da infância, o Centre for Innovation and Research in Childhood and Youth (CIRCY) (Centro para Inovação e Pesquisa em Infância e Juventude), criado em 2012, do qual atualmente faz parte.
} 
dos dados, participação em atividades da/na universidade e contato com o Centre for Innovation and Research in Childhood and Youth (CIRCY). O outro, as visitas a centros interdisciplinares de pesquisa da infância, localizados nas outras universidades, para conhecer os contextos em que foram criados/se inserem, entrevistar pesquisadores, ter acesso a suas dependências, documentos, bibliotecas.

A seguir, as informações conseguidas, em cada um dos movimentos.

\subsection{Na Universidade de Sussex, Inglaterra}

Uma das primeiras ações ao iniciar a pesquisa foi a atualização de leituras, tanto de periódicos quanto de livros da área dos estudos da infância. Em relação aos livros, a biblioteca da universidade tem uma significativa coleção de títulos no campo dos estudos da infância, incluindo alguns clássicos frequentemente citados em diversos artigos, aos quais não se tem acesso facilmente, como The Sociology of Childhood. Essencial readings, de Chris Jenks (1982), ou The History of Childhood, de Lloyd DeMause, de 1974, por exemplo. O acervo, contudo, carecia de atualização, pois publicações mais recentes ${ }^{60}$ não estavam lá.

A atualização de periódicos abrangeu, principalmente, a Childhood e a Children\&Society, revistas que constituem referência para pesquisadores do campo da infância. A Childhood ${ }^{61}$ é publicada pela SAGE journals trimestralmente, ou seja, são quatro edições

\footnotetext{
${ }^{60}$ Por exemplo, Priscilla Alderson, professora emérita de estudos da infância, publicou em 2013 Childhood Real and Imagined, livro que, no primeiro semestre de 2014, fundamentou três seminários, denominados Childhood, rights, research ethics and critical realism: New ways to research childhood, no Instituto de Educação da Universidade de Londres. Leena Alanen, da University of Jyväskylä, publicou, com Martti Siisiäinen, Fields and Capitals. Constructing local life, em 2011. Barry Mayall publicou A History of the Sociology of Childhood, em 2013. Vários outros livros do campo dos estudos da infância foram publicados.

${ }^{61} \mathrm{http}: / /$ chd.sagepub.com/
} 
anuais, uma delas temática. A Children\&Society ${ }^{62}$ é publicada pela Wiley em cinco edições anuais, uma delas temática. Ambas publicam uma média de 27 artigos por ano, excluídos os das edições especiais, as resenhas e editoriais.

Verifiquei os volumes publicados entre 2011 e 2013 em busca de artigos que trouxessem questões sobre interdisciplinaridade no estudo da infância como foco ou que discutissem a Sociologia da Infância como paradigma, como campo, como teoria. Parece oportuno destacar que Educação, Sociologia, Antropologia Social, Ciências Sociais e Serviço Social são áreas bastante representadas nos dois periódicos, mas há artigos originados nos campos da Saúde, da Comunicação, do Direito, da Psicologia, da Filosofia, da Criminologia e do Paisagismo. A diversidade de disciplinas/campos aos quais pertencem os autores dos artigos incrementa a discussão sobre a inter/multidisciplinaridade no estudo da infância.

De volta aos interesses da pesquisa, sobre a interdisciplinaridade, o conteúdo que se segue foi extraído da seção Abordagens interdisciplinares: contribuições do campo dos estudos da infância ${ }^{63}$, escrita por ocasião da realização da pesquisa.

Para abrir este segmento ${ }^{64}$, cabe uma citação de Thorne (2007), que indaga sobre o papel da interdisciplinaridade nos estudos da infância:

Estudos da infância são frequentemente descritos como um campo interdisciplinar de estudo. $O$ que, em locais e situações específicas, essa reivindicação significa? O que anima alguns estudiosos e praticantes a se moverem através das fronteiras das disciplinas acadêmicas tradicionais? Que caminhos interdisciplinares são cruzados, os quais parecem bloqueados e pressentidos - e por quê? Quais são os caminhos para um diálogo interdisciplinar fecundo e para colaboração no estudo de crianças

\footnotetext{
62 http://onlinelibrary.wiley.com/journal/10.1111/(ISSN)1099-0860

$63 \mathrm{Em}$ Como se conduz a pesquisa da infância quando a educação é mais um campo a compor seus estudos? Alguns elementos para discussão, Currículo sem Fronteiras, 2015.

${ }^{64}$ P. $85-88$.
} 
$e$ infâncias? Estamos criando tipos distintos de inquérito, ou principalmente fazendo interseções entre caminhos separados, bem estabelecidos, de conhecimento? (p.147)

As questões levam a recuperar um pouco da história da constituição do campo, que nas palavras de James (2010) tem a interdisciplinaridade em sua origem, ou seja, "teve suas raízes intelectuais em um contexto muito interdisciplinar - os workshops de etnografia sobre a infância que foram organizados por Judith Ennew ${ }^{65}$ e realizados em Cambridge nos anos $1980^{66 \prime \prime}$ (p.215). A pesquisadora argumenta que embora tenham sido convocados pelo campo da antropologia, foram frequentados por sociólogos, psicólogos, historiadores, geógrafos, advogados, ou seja, "pesquisadores e profissionais de diversas áreas se reuniram, já que compartilhavam interesse em um tema - 'crianças' e 'infância'”. (2010, p.215)

Alanen (2012), por sua vez, refere a revista Childhood ${ }^{67}$ como espaço de desenvolvimento da interdisciplinaridade, argumentando que "ao fornecer um local de encontro para pesquisadores de diferentes áreas, a revista ajudou a desenvolver o estudo de crianças e da infância em um campo multidisciplinar" (p.419) e acrescenta que a familiaridade com o trabalho de outros campos e a colaboração entre as fronteiras disciplinares foi favorável para interdisciplinaridade. A pesquisadora acrescenta que

\footnotetext{
${ }^{65} \mathrm{PhD}$ em antropologia social falecida em 4 de outubro de 2013.

${ }^{66}$ De acordo com Morrow, "na década de 1980, ela começou uma série de oficinas de etnografia da infância, a primeira das quais foi realizada em Kings College, Cambridge, em 1986, com 60 profissionais e acadêmicos de diferentes disciplinas. A primeira oficina teve como objetivo discutir os métodos adequados para o estudo de influências sociais e culturais sobre a infância, com a intenção de fornecer uma perspectiva social sobre a infância e trabalhar com as crianças como unidades de análise, para complementar e ampliar os modelos médicos, psicológicos e educacionais existentes. A segunda oficina da série foi realizada em Camrose, Alberta, Canadá, em 1987, e a terceira em Newnham College, Cambridge, em 1988, com foco na infância e política social - muitos membros do projeto Infância como fenômeno social participaram, e a oficina contribuiu para a produção do volume editado por Allison James e Alan Prout - Constructing and Reconstructing Childhood. A quarta oficina de etnografia da infância foi realizada no Zimbabwe em 1989 (e mais tarde, a quinta oficina foi realizada em Cingapura, em 2006)". (2014, p.152)

${ }^{67} \mathrm{http}: / /$ chd.sagepub.com/
} 
o campo de estudos da infância parece ter se tornado verdadeiramente multidisciplinar. Hoje, o campo é preenchido não só por psicólogos, sociólogos, antropólogos e historiadores, mas também por geógrafos, filósofos, estudiosos da ética, economistas e muitos mais. Reconhece-se que infância e criança são fenômenos complexos de fato; compreendê-los corretamente, e não apenas parcialmente, obriga qualquer disciplina a consultar pesquisadores de outras áreas disciplinares e desenvolver formas eficientes de comunicação e colaboração com eles. $O$ objetivo seria integrar a visão orientadora central dos estudos sociais da infância a noções compatíveis de crianças e da infância originários de outras importantes disciplinas relacionadas com as crianças: um quadro interdisciplinar integrado e abrangente. (ALANEN, 2012, p.419)

Assim como Alanen, Jacobs e Frickel (2009) também definem interdisciplinaridade como "comunicação e colaboração entre as disciplinas acadêmicas" (p.44), num trabalho que pretende uma "avaliação crítica" do conceito, por meio da revisão da literatura. Segundo eles (1) interdisciplinaridade nos dias de hoje não é apenas um princípio, ou uma metodologia, mas também, muitas vezes, condição para obter financiamento ou bolsas de estudo para pesquisa; e (2) há ampla literatura sobre o assunto, que perpassa temas como pedagogia interdisciplinar, práticas de conhecimento interdisciplinares, epistemologias interdisciplinares, além da construção formal de teoria ${ }^{68}$. Dizem os pesquisadores que

A literatura revista é caracterizada por considerável ambiguidade terminológica. Alguns estudiosos fazem distinções claras entre a investigação do que é interdisciplinar ou multidisciplinar (contribuições de dois ou mais campos para um problema de pesquisa), interdisciplinar ou pluridisciplinar (integração de conhecimentos originários de dois ou mais campos), ou transdisciplinar (conhecimento produzido conjuntamente por especialistas de disciplinas e práticos sociais) (ABOELELA et al., 2007, SALTER; HEARN, 1996). O objetivo subjacente destes termos é distinguir entre baixo, moderado e alto nível de interconexão ou de integração intelectual. ( $p .45)$

\footnotetext{
${ }^{68}$ Mencionam o Manual de Interdisciplinaridade, publicado pela Oxford University Press, em 2010.
} 
O artigo conclui apontando que "a relativa ausência de clareza epistêmica provavelmente tem impactos sobre a organização da investigação interdisciplinar $e$ sobre a trajetória das carreiras interdisciplinares." (Jacobs e Frickel, 2009, p.52)

O campo da geografia da infância, área de estudos e pesquisa que publica o periódico "Children's Geographies ${ }^{69 ",}$ também em 2009, promoveu debate sobre interdisciplinaridade, em discussão organizada pela Associação de Geógrafos Americanos. No ano seguinte, artigos curtos, derivados do debate, foram publicados na revista, compondo a seção "pontos de vista". Como Gagen (2010) explica no primeiro texto, "o objetivo do painel foi trazer à tona os vários domínios e direções da produção do conhecimento que constitui os estudos da infância e juventude" (p.213). Pode-se perguntar por que uma disciplina promoveria um debate sobre a interdisciplinaridade? Segundo Gagen (2010), "na discussão realizada, verificou-se que, assim como há uma variedade de perspectivas disciplinares no estudo da infância e juventude, há uma variedade de perspectivas sobre a natureza das operações disciplinares." (p.213) A geógrafa comenta as diversas posições dos pesquisadores presentes no debate, desde o reconhecimento de que o campo dos estudos da infância é e deve ser interdisciplinar até a referência ao risco que se corre ao pleitear a convergência de diferentes campos na pesquisa, o que poderia torná-la diluída e superficial. De qualquer modo há um reconhecimento da prática disciplinar e de sua inerente parcialidade.

Outra geógrafa, Pain (2010), na mesma publicação, reforça que "em seu sentido original e mais profundo, a pesquisa participativa não é uma mudança metodológica, mas uma

\footnotetext{
${ }^{69} \mathrm{http} / / /$ www.tandfonline.com/toc/cchg20/8/2\#.VF-taTRVneM
} 
perspectiva epistemológica e ontológica, sobre quem pergunta e responde às perguntas da pesquisa (FINE et al., 2007, CAHILL et al., 2008)." (p.224) A pesquisadora argumenta que

enquanto os debates sobre disciplinaridade frequentemente parecem assentados num pressuposto básico de que "a disciplina" é o lugar da orientação filosófica/teoria/abordagem metodológica; e "o campo", mero local de prática/engajamento/empirismo, percebe-se que ao longo dos anos de trabalho participativo em geografias da infância e juventude os binarismos foram encobertos. E assim, as relações entre teoria/prática $e$ disciplinaridade/caminho-além-da-disciplinaridade colidiram e se confundiram em maneiras produtivas, intelectual e politicamente (2010, p.224)

Nas palavras de Alanen (2012) "disciplinaridade e interdisciplinaridade não são adversárias, não devem competir entre si, pois há uma relação de interdependência entre elas". (p.421) Ou seja,

para ser interdisciplinar é preciso primeiro ser proficiente em uma disciplina própria. Consequentemente, para fazer os estudos da infância interdisciplinares prosperarem, precisamos ter uma sociologia da infância forte, sólidos estudos históricos da infância, uma geografia da infância bem-sucedida, e assim por diante. Mas isso, por sua vez, requer que a subdisciplina acumule e nutra fortes ligações com a "disciplina mãe" $e$ desenvolva uma identidade disciplinar forte. Pode haver problemas se esse caminho não for seguido. (p.421, grifo no original)

Cook (2010) critica o uso do termo interdisciplinar, que, para ele, "evoca imagens de algum ponto de convergência, no qual se podem recolher os insights de praticamente todas as disciplinas - uma espécie de posição meta-disciplinar" (p.222) que Ihe parece arrogante e ambiciosa, pois nem todos os campos de conhecimento estão representados nos estudos da infância. Segundo ele,

temos estudiosos em sociologia, antropologia, religião e ética, história, psicologia e literatura, que focalizam as crianças e a infância. Mas, e a medicina? Os estudos de saúde? A biologia? [...] Educação transdisciplinar e pesquisa têm a melhor chance de realizar o seu potencial quando os praticantes não negam suas origens disciplinares, mas as abraçam por sua particularidade e seletividade. (COOK, 2010, p.222) 
O debate sobre interdisciplinaridade não se esgota nessas referências, mas trata-se de importante questão a ser mais e mais discutida. Abordagens interdisciplinares perpassam os aportes teóricos e podem desencadear possibilidades metodológicas de pesquisa, como estudos comparativos, longitudinais, geracionais, por exemplo. Neste sentido, aspectos das configurações disciplinar e interdisciplinar podem ser discutidos a partir de contextos nos quais se situam, com vistas a apontar elementos que compõem os desafios éticos e metodológicos presentes na pesquisa da infância.

A respeito da teorização da infância, em seu editorial para o primeiro número do periódico Childhood, em 2014, Alanen recupera o desconforto causado pelo discurso proferido na cerimônia de abertura da reunião da Associação Europeia de Sociologia (ESA) de 2011, por um sociólogo que tinha a firme convicção de que a infância é uma fase preparatória para idade adulta. Ela argumenta que

\begin{abstract}
Um forte investimento em teorizar infância foi considerado como procedimento necessário, e a decisão foi tomada em Genebra, para emitir a chamada de trabalhos para a reunião intermediária da rede, com o título "Teorizar a infância". Sociólogos da infância foram convidados a vir para discutir uma variedade de tópicos, tais como o lugar e a relevância dos "clássicos" da disciplina (Marx, Durkheim, Weber) na sociologia da infância e uma variedade de abordagens mais recentes (por exemplo, Bourdieu, Luhmann, Foucault) e direções (por exemplo, teorias de rede, teorias de espacialidade e de direitos) e sua relevância para o desenvolvimento da Sociologia da Infância. (ALANEN, 2014, p.4)
\end{abstract}

Cabe destacar que o investimento na teorização da infância pode ser encontrado no periódico Children's Geographies ${ }^{70}$, que apresenta interessante discussão sobre o paradigma dos estudos da infância em 2012a: o número especial ${ }^{71}$, organizado pelas geógrafas escocesas Tisdall e Punch, "Exploring children and young people's

\footnotetext{
70 Publicado pela Taylor \& Francis.

${ }^{71}$ http://www.tandfonline.com/toc/cchg20/10/3\#.U1uWi1VdWTJ
} 
relationships across Majority and Minority Worlds". O volume é o resultado de uma série de seminários desenvolvidos entre abril de 2010 e outubro de 2011, promovidos pelo Centre for Research on Families and Relationships (Centro de Pesquisa sobre Famílias e Relações) $)^{72}$ e financiados pelo UK's Economic and Social Research Council (Conselho de Pesquisa Econômica e Social do Reino Unido). O objetivo dos seminários, destacam-se Tisdall e Punch no editorial, era propor um desafio para o campo dos estudos da infância, a partir de novas teorizações acerca da agência de crianças e jovens, considerando principalmente as diferenças entre o sul e o norte (mundos majoritário e minoritário ou terceiro e primeiro mundos) (p.241). O volume especial tem oito artigos e dois deles são particularmente interessantes para a discussão sobre teoria, o das organizadoras, "Not so 'new'? Looking critically at childhood studies", e o de Mayall, "An afterword: some reflections on a seminar series", que, como indica o título, apresenta uma síntese que fecha os seminários.

Teorizar infância - ou (re) teorizar, conforme Alanen (2014, p.4) - foi a temática da reunião intermediária (mid-term Symposium) da Research Network for the Sociology of Children and Childhood (Rede de Pesquisa 'Sociologia das Crianças e da Infância') (RN4), da European Sociological Association (Associação Europeia de Sociologia) (ESA), no verão de 2012:

30 sociólogos reunidos em Jyväskylä (Finlândia), onde cerca de 20 trabalhos foram apresentados e discutidos sobre o tema da reunião. Esperemos que este pequeno encontro seja um sinal de interesse grande e crescente, bem como um incentivo, entre os sociólogos da infância, de repensar o papel da teoria em seu trabalho. (Id.)

\footnotetext{
72 Mantido por um consórcio de universidades escocesas.
} 
O exercício foi repetido na reunião seguinte da ESA, em Turim, 2013, organizado em 24 sessões, dentre as quais Theoretical issues in the sociology of childhood (Questões teóricas na Sociologia da Infância), com quatro trabalhos. A proposta da reunião intermediária da RN4, em Modena ${ }^{73}$, em 2014, tinha como tema Theorising Childhood: Citizenship, Rights, Participation (Teorizar a infância: cidadania, direitos, participação). Neste, foram apresentadas quinze comunicações, sendo que as cinco primeiras ofereciam uma visão mais ampla da discussão e, em seguida, pesquisadores de diferentes universidades e países apresentaram seus textos, os quais foram discutidos pelos colegas que participavam do encontro. O debate entre os colegas europeus inclui questões diretas e explicações sobre pontos considerados inconsistentes ou superficialmente explorados.

Apontados os principais pontos teórico-metodológicos da constituição e desenvolvimento do campo da Sociologia da Infância na Europa, interdisciplinaridade e produção de teoria, apresenta-se, a seguir, alguns contextos nos quais são encontrados.

\subsubsection{Centre for Innovation and Research in Childhood and Youth (CIRCY)}

Há, na Universidade de Sussex, um núcleo interdisciplinar: o Centre for Innovation and Research in Childhood and Youth (CIRCY) (Centro de Inovação e Pesquisa em Infância e Juventude). Não foi possível estabelecer contato e agendar com o/a dirigente e ao menos dois pesquisadores, como era a proposta prevista para os demais centros, mas

\footnotetext{
${ }^{73}$ Reunião em que participei como ouvinte.
} 
foi realizada uma entrevista, em maio de 2014. Dessa maneira, o contato será descrito e comentado a seguir, mas não fará parte da análise.

De acordo com a página da Universidade de Sussex,

O CIRCY foi iniciado na Universidade de Sussex em 2012, reunindo pesquisa, bolsas de estudos e conhecimentos sobre infância e juventude. É um centro interdisciplinar e interuniversitário, que inclui pesquisadores das ciências sociais e da vida, artes, ciências humanas e campos profissionais, incluindo o trabalho social, o direito, a educação e a saúde. (Http://www.sussex.ac.uk/esw/circy/index)

Para estabelecer um primeiro contato com os pesquisadores do $\mathrm{CIRCY}$, participei de um workshop denominado Childhood, Youth and European Citizenship (Infância, Juventude e a Cidadania Europeia) ${ }^{74}$, evento organizado conjuntamente pelo Sussex European Institute (Instituto Europeu de Sussex), por uma organização chamada New Europeans (Novos Europeus) e pelo próprio CIRCY, representado pela profa. Sevasti-Melissa Nolas, no final de abril de 2014.

Alguns dias depois, entrevistei a Profa. Nolas, uma das dirigentes do CIRCY, para conhecer o funcionamento do centro. Ela informou que o corpo diretivo é constituído por quatro pesquisadores: duas diretoras, Rachel Thomson e Janet Boddy, e dois gestores de apoio, Robin Banerjee e ela.

A Profa. Nolas destaca que participar deste centro foi seu primeiro contato com o campo dos estudos da infância e da juventude: "Cheguei em setembro de 2011 [...] Foi quando o $\mathrm{CIRCY}$ foi criado. Ao mesmo tempo, havia o mestrado em estudos da infância e da juventude. Então, era esse o programa de pós-graduação em estudos da infância e da

\footnotetext{
${ }^{74} \mathrm{O}$ encontro era parte de uma série de atividades de um projeto denominado Connecting with Citizens (Conectando com os Cidadãos), patrocinado pela representação da Comissão Europeia, no Reino Unido.
} 
juventude. Eu estava envolvida com as aulas de um dos dois módulos principais do programa, e projetei o módulo Desenvolvimento atual nas Políticas e nas Práticas da Infância e da Juventude".

Sobre o caráter interdisciplinar do CIRCY, a Profa. Nolas afirma que "o que Rachel [Thomson] fez, que acho que foi ótimo, foi que ela abriu para a participação de colegas do Centro de Artes, das Humanidades e de outras ciências sociais em Sussex. Em termos de nossa composição, somos interdisciplinares. Então, nós temos colegas do Inglês, da História, da Psicologia, da Sociologia e do Direito, acho. Nós temos algumas ligações com o Centro Médico, a Educação e o Serviço Social. Então, nesse sentido, é interdisciplinar. Agora, o que acontece é que algumas áreas das diferentes disciplinas são mais ativas do que outras, mas acho que é assim mesmo".

Interessante destacar que ela considera o CIRCY interdisciplinar também porque esta é uma característica da Universidade. Em suas palavras, "penso que Sussex seja conhecida por sua interdisciplinaridade. Houve muitas mudanças na universidade nos últimos 20 anos. O modo pelo qual a universidade costumava ser organizada era em torno da ideia de interdisciplinaridade. Então, era comum haver escolas: Escola de Estudos Europeus e Escola de CCS - Cultura, Comunidade e Sociedade, acho. Não lembro com exatidão. Escola de Estudos Cognitivos.... Então, nos anos 2000, acho, houve algumas mudanças parciais, [...] Assim que criou os departamentos, Sussex obteve classificações mais altas. Penso que o que a universidade tem tentado fazer com iniciativas como o CIRCY é recapturar, talvez, um pouco daquela interdisciplinaridade".

Embora não tenha conseguido entrevistar outros pesquisadores do CIRCY, por questões de agenda, as considerações da Profa. Nolas registram a importância da 
interdisciplinaridade no centro e remetem à discussão sobre a coexistência de centros interdisciplinares de pesquisa e departamentos na universidade, como no texto de Jacobs e Frickel (2009). Ainda que essa temática não constitua o foco do estudo, ela será comentada em seção posterior.

\section{2. Centros interdisciplinares de pesquisa em infância}

Retomando as visitas aos quatro centros interdisciplinares inicialmente previstos, estas foram realizadas entre os meses de março e maio de 2014, e consistiram em (1) contato com o/a dirigente e ao menos dois pesquisadores, como já apresentado, sendo que era esperado que um deles pudesse ser pesquisador visitante; (2) leitura/acesso a livros e artigos produzidos, aos conteúdos de pesquisas em andamento. Cada visita durou dois dias. As questões formuladas para todos os entrevistados eram sobre natureza/trabalho do centro; funcionamento e financiamento da pesquisa; os temas de pesquisa; o impacto acadêmico ou político da pesquisa/do centro; as referências teóricas e as abordagens metodológicas pertinentes; a interdisciplinaridade; a promoção do diálogo entre as áreas/investigação conjunta; o papel da educação numa perspectiva interdisciplinar, não necessariamente nesta ordem.

A seguir, são apresentadas as entrevistas, de maneira descritiva. Parece importante notar que foram realizadas em cada centro de pesquisa e têm duração de uma hora, em média. Todas as entrevistas foram gravadas em áudio e, posteriormente, enviadas para transcrição por um profissional. Transcritas, foram enviadas para cada um dos entrevistados para que verificassem se seu depoimento estava correto. Algumas foram corrigidas pelo entrevistado e outras mantidas como estavam. Evidentemente, as 
entrevistas realizadas em inglês foram traduzidas e, neste sentido, procurei ser o mais fiel possível ao que foi dito, embora tenha buscado expressões e palavras equivalentes, em português, para melhor compreensão dos conteúdos apresentados. As entrevistas em português de Portugal foram mantidas, sem intervenção.

Para caracterizar o entrevistado e o centro de pesquisa, as ideias e os contextos em que se desenvolvem, foram selecionados trechos das falas dos pesquisadores. Alguns estudiosos são mais prolixos do que outros, alguns defendem determinadas ideias com maior veemência, e estas características particularizam as falas dos entrevistados, como se verá. As análises comporão outra seção.

\subsubsection{Centro de Investigação em Estudos da Criança $(\mathrm{CIEC})^{75}$, Universidade do Minho, Portugal}

Anteriormente denominado Instituto de Estudos da Criança, em 2011 tornou-se Centro de Investigação em Estudos da Criança (CIEC), de natureza multi e interdisciplinar, que visa a pesquisa científica no campo dos Estudos da Criança. Seu objetivo é definido no âmbito dos Estudos da Infância, ou seja, compreender o mundo das crianças, o seu desenvolvimento e bem-estar. Organizado em dois grandes grupos de pesquisa, contextos, cotidianos e bem-estar das crianças e aprendizagem e desenvolvimento da criança, oferece cinco linhas de pesquisa, a saber: Contextos e práticas sociais das crianças; Saúde, ambiente e educação física; Profissionais de infância; Recursos pedagógicos; Produções culturais.

\footnotetext{
75 http://www.ciec-uminho.org/index_pt.html
} 
O CIEC está instalado numa sala, no piso térreo do edifício do Instituto de Educação (IE), do qual faz parte. No contexto do IE, a atividade científica é realizada em dois centros de pesquisa, o CIEC e o Centro de Investigação em Educação (CIEd).

Foram entrevistados a diretora, Graça Simões de Carvalho, o pesquisador Manuel Jacinto Sarmento, diretor do centro por oito anos (2001 a 2009) e, uma de suas doutorandas, a venezuelana Grecia Rodriguez Pinto, visto que não havia pesquisadores visitantes por ocasião da ida a Braga.

\subsubsection{Graça Simões de Carvalho}

Coordenadora do CIEC, professora titular, interessada em Biologia da Educação, Educação e Saúde e Educação Ambiental

De acordo com a Profa. Carvalho, o CIEC "é uma unidade de pesquisa, financiada pelo Ministério da Ciência e Desenvolvimento Tecnológico, FCT, que apoia pesquisas em Portugal". Ela conta que as atividades de pesquisa foram iniciadas em 1994, quando o centro foi inaugurado, e, na ocasião, a pesquisa era somente sobre educação.

No início, o Instituto de Estudos da Criança (IEC) foi uma unidade de formação de professores do ensino primário e educadores de infância e reuniu professores das áreas de conhecimento formal - por exemplo: História, Biologia e Matemática. Naquele contexto, a ideia de pesquisa era ir "para além de ser da formação, ou seja, ensiná-los a ensinar", integrando a Saúde Infantil e a Sociologia da Infância, como a profa. Carvalho apontou. Segundo ela, "o professor Manuel Sarmento, que liderou muito, e também a professora Natália Fernandes" tratavam do trabalho infantil, presente na região. "Eles, 
portanto, faziam estudos e tinham relações com entidades da Segurança Social, de outras entidades que com elas trabalhavam. Mas eles faziam trabalhos de pesquisa, avaliação e sugestão para melhoria das condições infantis. E eu, que vinha já da área da Saúde, portanto sou bióloga, mas doutorei-me em Imunologia, na Inglaterra, em Cambridge", pesquisava sobre "a saúde das crianças, na área de Educação e Promoção da Saúde". Revela que "o meu grupo é mais na área da Educação e Promoção da Saúde, ou seja, por um lado a formação dos professores para dar os conteúdos de Biologia e Saúde, e, por outro lado, fora da sala de aula, implementarem programas de Saúde e Educação Ambiental", no sentido de "trabalhar mais com as atitudes, os valores, os comportamentos, que é uma matéria sempre mais difícil para os professores levarem a cabo".

De acordo com ela, "ao longo dos anos, a componente da Sociologia da Infância, da Saúde Infantil, das questões de bullying, que também tem muito a ver com a Saúde Ambiental, de relações interpessoais, a componente da Psicologia também foi-se desenvolvendo muito. Isto ao nível escolar. Também se foi desenvolvendo, e que atualmente é uma área bastante desenvolvida, com bastante atividade, tem a ver com as questões da família. Portanto, as crianças na família e problemas de parentalidade".

Questionada sobre oportunidades de diálogo entre as diferentes áreas, diz que "na altura da preparação de projetos para financiamento externo, às vezes as pessoas associam-se. Tem um dado projeto e então vão buscar elementos de várias áreas para construir o projeto. [...] E, portanto, aí já vai haver ligação. Mas, o nosso tempo disponível é pouquíssimo. Quer dizer, há uma sobrecarga de aulas enorme, é a componente administrativa imensa". Segundo a Profa. Carvalho, a equipe tem muitas 
aulas para dar e alunos para orientar. Além disso, alguns professores se aposentam e não há substituição, o que sobrecarrega os outros. Mas algumas reuniões têm sido realizadas como, por exemplo, "eu que sou da área da Saúde Infantil e a professora Beatriz Pereira, que é da área da Educação Física e Lazer, nós colaboramos. Temos o Seminário de Educação Física, Lazer e Saúde, que se organiza de dois em dois anos, já desde 2003. [...] E a partir de 2007, penso eu, passou a ser nos anos intercalares no Brasil".

Quanto ao impacto das pesquisas sobre as políticas, a Profa. Carvalho diz que o CIEC teve algum impacto em nível nacional, quando era o Instituto de Estudos da Criança. “Depois deu-se a fusão do Instituto dos Estudos da Criança com o Instituto de Educação e eu até prefiro não falar sobre isso, porque foi uma descaracterização. E a única coisa que resta é o nosso centro de pesquisa. Mesmo assim, tem sido uma luta para sobrevivermos dentro do ambiente". Conta que nos "fins de anos 1990, 2000, por volta disso, nós tínhamos um contacto muito próximo com a Assembleia da República. Ou seja, colaboramos muito em levantamentos, estudos que o Parlamento fazia e, então, pediam o nosso apoio". E acrescenta: “Mas temos tido também, por exemplo, a rede do pré-escolar. Um colega nosso, que agora já está reformado, está aposentado, que é o professor João Formosinho, que foi quem liderou isso no país, ligado ao Ministério, portanto, a dar o apoio direto" na formação da rede em todo o país.

A respeito da pesquisa interdisciplinar, a Profa. Carvalho pondera que "o que nos une será talvez a perspetiva multidisciplinar. Portanto, todos assumimos que estamos a trabalhar para os Estudos da Criança, numa perspetiva em que podemos fazer colaborações com os colegas em que cada um trabalha dentro da sua área. Portanto, 
em princípio, ninguém vai sair da área em que está a trabalhar. Convida o outro para trabalhar, para estudar um dado problema. Portanto, nós estamos organizados em termos de grupos, são dois grupos e depois dentro de cada grupo são as áreas mais afins, não é?"

Perguntada sobre o objeto do centro, diz que "no nosso caso, no nosso centro o objeto é a criança em que uma das componentes, que é a mais forte quer se queira, quer não, é a componente da Educação, da formação de professores". E acrescenta que o papel da Educação é forte porque todos os grupos são em primeiro lugar docentes, de acordo com seus contratos de trabalho, e, depois, pesquisadores, por conta dos doutorados, ou seja, "nós temos uma produtividade muito elevada em termos de doutoramentos. A escola, no seu todo, mas nós contribuímos bastante, mais do que o outro centro."

Completa afirmando que "o centro tem avançado muito, teve um aumento de produtividade, em termos comparativos [...] Não só, portanto, no nível de doutorado, mas também na produção científica". A professora comenta que ao "centro faltam bolseiros. Quer dizer, pessoas que possam estar a 100\% para fazer pesquisa. E não só pesquisa. Fazerem divulgação do que se está a fazer, das atividades, relacionarem-se com as escolas, com a comunidade." E lamenta a crise econômica que cortou as bolsas de estudo.

\subsubsection{Manuel Jacinto Sarmento}

Professor associado com agregação, diretor do IEC por oito anos (2001-2009), pesquisador de estudos da infância. 
Em primeiro lugar, o Prof. Sarmento explica as mudanças no CIEC pela perspectiva histórica. Ele conta que "O Centro de Investigação em Estudos da Criança é um centro de pesquisa que nasce inicialmente numa escola universitária centrada nos Estudos da Criança. Essa escola foi, entretanto, inserida dentro de um instituto de educação. [...]a reestruturação da Universidade do Minho [considerou] que era mais útil separar a [área da] Psicologia da [área da] Educação, que até então estavam ligadas, portanto, a Psicologia autonomizou-se, tem hoje uma escola própria, [...] e os Estudos da Criança [foram inseridos] dentro do Instituto da Educação". Dessa forma, "considerou-se que os Estudos da Criança eram basicamente uma área de pesquisa e de ensino e não propriamente uma base para uma estrutura funcional de alocação de recursos humanos. De forma que o atual Instituto de Educação da Universidade do Minho não tem nenhum departamento de Estudos da Criança, mas tem formação avançada em Estudos da Criança, mestrado e doutoramento, e tem um centro de pesquisa em Estudos da Criança".

Acrescenta que "hoje o Centro de Estudos da Criança é, portanto, uma estrutura, digamos, um pouco híbrida, um pouco impura, não nasce de um projeto científico perfeitamente claro, que resulta de um processo histórico institucional que gerou a situação existente. Ao longo dos últimos meses, sobretudo, tem-se vindo, no entanto, a trabalhar aquilo que é a especificidade, portanto, de investigação em Estudos da Criança face à Educação. E essa especificidade permitiu desenvolver, em alguns grupos de pesquisa ou em particular daquilo que internamente se designa por áreas temáticas, uma abordagem mais claramente centrada nos Estudos da Criança. É o caso da área temática que eu coordeno, que tem a ver com os contextos e práticas sociais das 
crianças e cujo objeto está claramente definido no âmbito daquilo que são as políticas e as práticas sociais da infância, articulando com dimensões de uma criança nessa idade, a questão dos direitos, a questão do depoimento institucional de crianças que estão... das relações da criança no interior das instituições, em particular da família e da escola. Mas o foco será sempre a criança como sujeito social e como membro de um grupo geracional que é a infância”.

O Prof. Sarmento contesta a ideia de estudos interdisciplinares da infância e acredita que o termo multidisciplinar é mais adequado para aplicar ao conjunto de disciplinas que se aproximam para os estudos da infância: "a interdisciplinaridade é uma coisa que, digamos, a que se aspira, mas talvez seja mais correto definir o nosso centro, o Centro de Investigação em Estudos da Criança, como centro multidisciplinar, não um centro interdisciplinar. Ou seja, um centro no qual concorrem várias disciplinas e em que o cruzamento é ainda, digamos, um projeto em curso, alguma coisa que está a ser estruturada com algumas dificuldades". E completa: "a interdisciplinaridade costumo definir como a produção de um conhecimento científico que resulta das afinidades eletivas entre disciplinas diferentes. E, portanto, encontro entre setores, denominadores comuns. Neste domínio, a nossa articulação da Sociologia da Infância tem sido, sobretudo, claramente com as Artes e um pouco também com as Ciências do Lazer. O nosso centro não tem, infelizmente, gente da área da História, da área da Antropologia".

Segundo ele, o centro estuda "a criança como um todo, como um objeto próprio, um objeto científico, e a infância enquanto categoria geracional". E completa: "O CIEC é, digamos, um cento de pesquisa em que o trabalho multidisciplinar vai vivendo desta 
tensão entre dois objetos que ali se cruzam e que tem por exemplo uma deriva relativamente influente na focalização do profissional que trabalha com a criança. Portanto, já não é tanto a criança que está em causa, é o profissional que trabalha com a criança. Eu acho que os Estudos da Criança podem se abrir ao diálogo com as abordagens sobre, por exemplo, os professores, os enfermeiros, os assistentes sociais. Mas é outra coisa, portanto: essas abordagens são abordagens que têm que ser estabelecidas, devem ser estabelecidas, mas sem que, em todo o caso, se perca o foco fundamental". Diz o Prof. Sarmento que "o Centro de Investigação em Estudos da Criança é o primeiro e único em Portugal centrado neste objeto. O que foi o Instituto de Estudos da Criança foi o primeiro e único em Portugal que criou este objeto. Nesse sentido, houve desenvolvimentos importantes, mas esta relativa novidade, digamos, deste campo de estudos, apesar dos contatos internacionais relativamente consistentes e permanentes".

A respeito do impacto das pesquisas, refere que "há um momento inicial, que é um momento muito marcante na sociedade portuguesa, na construção deste objeto e do trabalho que é realizado, e que deu origem a duas publicações: uma generalista, portanto, abordagem conceitual, As crianças: contextos e identidades ${ }^{76}$, e uma segunda, de avaliação, mas, se quisermos, mais do que avaliação, de recenseamento e mapeamento daquilo que era a produção científica sobre a criança em Portugal. [...] Quer uma quer outra dessas publicações tiveram bastante impacto na sociedade portuguesa [...] na medida em que foram reconfiguradas, digamos, as fronteiras de um campo. Permitiram agregar uma série de investigadores em torno desse campo, ainda

\footnotetext{
${ }^{76}$ Livro organizado pelo Prof. Sarmento com o Prof. Dr. Manuel Pinto, publicado em 1997.
} 
que eles possam ter vindo de outras origens, por exemplo, das Ciências da Comunicação, da Sociologia da Família, alguns do Serviço Social, da Psicologia. Isso permitiu a realização de uma forma sistemática de algumas reuniões científicas centradas de fato nos Estudos da Criança de grande impacto, não apenas em Portugal, mas também no mundo de língua portuguesa. Refiro-me, por exemplo, ao congresso de 2000, Os Mundos Sociais e Culturais da Infância, depois mais dois congressos que realizámos em anos sucessivos, um em 2004, outro em $2008^{77}$. Isto teve também influência do ponto de vista da configuração de algumas políticas públicas onde nós fomos interlocutores diretos como peritos chamados para a construção de alguns dos projectos". Fizeram avaliação das Comissões de Proteção de Crianças e Jovens, assim como do Plano para a Erradicação do Trabalho Infantil, além de trabalhar em outros projetos.

A promoção de políticas para a infância, contudo, passa por um período de recessão, segundo o professor, "que tem a ver com o modo como se reconfigurou o Estado no combate à crise, como ele se desenvolveu quanto crítica e combate ao Estado Social, emergência de uma forma radicalizada dos princípios da economia de mercado e, portanto, das lógicas neoliberais, contração das políticas sociais". Além desta razão, "a emergência da crise social [...] fez também de alguma maneira retirar àquilo que era a enorme visibilidade da infância na sociedade portuguesa o seu papel primordial. Hoje, a questão dos direitos da criança não é uma questão tematizada em Portugal". Assim, “ainda que a nossa intervenção hoje esteja muito próxima daquilo que são organizações sociais e coletivas que trabalham sobre as questões da infância, como por exemplo, o último livro que organizei e publiquei é sobre a pobreza infantil, foi feito em articulação

\footnotetext{
77 I Congresso Internacional em Estudos da Criança - Infâncias Possíveis, Mundos Reais - promovido pelo Instituto de Estudos da Criança (IEC).
} 
com uma rede europeia que tem cá a sua expressão de combate à pobreza. Em contrapartida, de alguma forma, teremos compensado isso com uma maior afirmação do nosso projeto formativo. Hoje, claramente estamos mais consolidados do ponto de vista de formação avançada em Estudos da Criança, sobretudo na área do doutoramento e pós-doutoramento, onde temos uma articulação forte com, sobretudo, os vários países de expressão portuguesa".

Segundo ele, no mundo de língua portuguesa, " o nosso trabalho é sobretudo marcado pela afirmação basicamente de dois ou três eixos essenciais no ponto de vista da produção teórica. Por um lado, o desenvolvimento efetivamente da Sociologia da Infância, dos seus construtos fundamentais. Em segundo lugar, o desenvolvimento de metodologias de pesquisa com crianças, em particular as metodologias participativas, as metodologias visuais, nas quais temos, enfim, aprofundado e desenvolvido um pouco e, portanto, nesse sentido temos trabalhado bastante. E em terceiro lugar, aspectos que são contributos, que podem, de alguma forma, ter uma dimensão ainda mais transversal; [...] contributos que podem também ter efeitos nos próprios universos linguísticos, anglo-saxónicos, sobretudo, onde os Estudos da Criança estão mais desenvolvidos e têm vindo a produzir mais trabalho".

Perguntado sobre a relação entre a educação e a infância, o Prof. Sarmento afirma "acho que nós aí fizemos progressos significativos e fizemos progressos no campo português, claramente. Que foi a de partir da abordagem da criança, e, portanto, da recusa da segmentação da criança e da sua redução ao papel institucional do aluno, isso permitenos pensar em todo o caso esse papel institucional. Quer dizer, o que é isto, como é a criança para além da sua condição de aluno, criança e adolescente, enfim, considerando 
a criança dentro da categoria geracional da infância, portanto, com margens etárias um pouco mais dilatadas. E essa reflexão, portanto, pensar a criança que está para além do aluno e a sua implicação no aluno, tem-nos permitido introduzir alguns termos de reflexão teórica-conceitual na sociedade portuguesa e na comunidade acadêmica portuguesa que estavam completamente ausentes. Por exemplo, a participação decisória da criança na organização escolar, que é um tema ausente até agora na reflexão sociológica da educação em Portugal e que nós introduzimos. Portanto, os estudos que têm sido feitos sobre a participação da criança na escola são estudos nossos. Uma outra dimensão é exatamente a reconfiguração do ofício do aluno [...] em função das alterações nas construções sociais da infância, na sua relação, por exemplo, com as tecnologias da informação e comunicação. O modo como hoje o ofício do aluno é de alguma forma um ofício de gestão da comunicação e da informação e como tudo isso potencia uma alteração e, pelo menos, uma outra colocação em perspectiva da relação de aprendizagem e da relação de interação com o adulto. [...] também temos trabalhado, a partir de aproximações antropológicas e de natureza etnográfica, como a brincadeira e a atividade lúdica, se incorporam no campo educativo para além da Educação Infantil".

Aponta "as implicações de uma reflexão sociológica da infância, na infância como ator social, recusa da sua fragmentação, quais as políticas públicas para a Educação Infantil, que é outro trabalho que também estamos a produzir. Creio que a reversão do olhar estritamente sociológico da infância sobre a Educação tem boas potencialidades e temos aí feito algumas sinalizações e temos feito alguns progressos também". 


\subsubsection{Grecia Rodriguez Pinto}

Jornalista, estudante de doutoramento

Vinda da Venezuela, está em Portugal desde 2010, fazendo um doutorado integral com bolsa Erasmus Mundus. Ela conta que "fiz mestrado em Estudos Internacionais. Depois, aqui na Europa, vim para fazer também um mestrado em Mídia e Educação. E, como sempre, a educação tem sido um tema que creio que todo o comunicador social tem que ter em foco. Queria continuar a trabalhar sobre esse tema e com o olhar na infância. [...] Comecei desde muito jovem a trabalhar com crianças, na área de rádio. Crianças como comunicadoras infantis na rádio". Está finalizando o doutorado.

Acrescenta que "quando eu vim para cá, eu propus para o professor [Sarmento] que agora, desde uma perspectiva da Sociologia da Infância, eu queria começar a trabalhar com crianças educomunicadoras sem fronteiras. Abrir um pouco a lente e trabalhar com elas esse conceito, da educação através da comunicação e da comunicação através da educação, a educomunicação... E também sem fronteiras, um pouco, agora tenho outro cenário, outras crianças, de zonas rurais e também crianças lusas. Falam a língua portuguesa. [...] eu queria analisar estas diferenças e ver qual é a contribuição das crianças na criação, produção e integração de conhecimento, porque eu parto de que elas têm conhecimento, são seres capazes, plenos de direitos. E ... esse conhecimento pode integrá-lo ao seu ser com o suporte da linguagem midiática e as novas terminologias, a partir da perspectiva da educomunicação e da Sociologia da Infância. Essa é minha proposta".

Sua pesquisa prevê uma metodologia participativa com crianças, "uma metodologia muito nova, pioneira, creio que temos que ser consequentes e crer que é possível 
convidar as crianças como parte de tua pesquisa, como coinvestigadoras, esse tem sido o princípio de minha investigação. [...] Foram convidadas para escrever, para elas assinarem um projeto coletivo compartilhado e, durante todas as fases do projeto, elas foram consultadas".

O estudo é realizado em Ponte de Lima, zona rural, e foi iniciado em uma escola, um centro de educação ambiental. Segundo Grecia, "como objetivo geral eu tenho a analisar, a partir da cultura e gramática infantil, quais são as características, ações e competências que se geram nas crianças quando são sujeitos de conhecimento e atores sociais em ambientes próximos à natureza e em contextos interculturais, utilizando a cooperação, a educomunicação e o suporte da linguagem midiática das novas tecnologias. [...] Logo estou analisando a ludicidade, a interação, reinvenção, imaginação, a interculturalidade, afetividade".

A doutoranda explica que "foi possível registrar essa associação que nós temos lá na Venezuela, agora aqui. Registramos uma associação que agora se chama Soy Niño, Sou Criança. Antes era Soy Niño. Agora a Associação é Soy Niño, Sou Criança. E agora essas crianças são promotoras desta associação. E este tipo de trabalho foram os primeiros encontros. Lá, no trabalho de campo. Falar, escutar, gerar dinâmicas conscientes, abertas que estimulem suas próprias capacidades". E completa "a partir da segunda fase do trabalho surgiu a possibilidade de publicar os trabalhos na mídia. No jornal. Uma aliança com o Diário do Minho. E elas então fazem os guiões de rádio. Que é o conhecimento delas ilustrado, as fotografias e os textos que elas criam sobre sua comunidade". 
Finaliza afirmando que "Então, esse tipo de coisa, ambiente, pedagogia, comunicação, tudo tem que estar interligado. E a criança no centro."

\subsubsection{Interdisziplinären Zentrums Kindheiten.Gesellschaften (IZKG) ${ }^{78}$, Bergischen}

Universität Wuppertal (Interdisciplinary Centre Childhoods.Societies, University of Wuppertal, Germany)

Seguiu-se a visita ao Centro Interdisciplinar Childhoods. Societies (Infâncias. Sociedades), da Universidade de Wuppertal, na Alemanha, que, voltado para a pesquisa interdisciplinar da infância, busca o pluralismo, tanto do ponto de vista das abordagens teóricas quanto da diversidade das vidas das crianças.

Criado em 2010, surgiu do seminário internacional Kindheitforschung: Geschichten und Perspektiven (Pesquisa da infância: história e perspectivas), que reuniu os principais pesquisadores dos estudos da infância, trabalha com pesquisa teórica e empírica a partir das crianças como atores sociais.

Entrevistei seu diretor, Heinz Sünker, do campo da Pedagogia Social, criador do centro; Rita Braches-Chyrek, professora de Pedagogia Social na University of Bamberg, uma das fundadoras do centro, e Anneta Potsi, da Faculty of Educational Science/Research School Education and Capabilities, University of Bielefeld, pós-doutoranda visitante.

\footnotetext{
${ }^{78}$ www.izkg.uni-wuppertal.de/
} 


\subsubsection{Heinz Sünker}

Diretor do Centro de Estudos Internacionais em Política Social e Serviço Social; coordenador do Centro Interdisciplinar Childhoods.Societies.

O Prof. Sünker começa por explicar o nome do centro. Ele disse que estão "muito orgulhosos desta invenção '[...]' Porque é um longo debate, uma longa tradição no debate, a infância e a sociedade estão conectadas, mas o problema é de que forma os temas estão conectados e como você pode lidar com as conexões, com as contradições e as tensões e com os diferentes níveis de relacionamentos. E, assim, pensei que a maneira mais fácil de escapar de todos estes problemas seria dizer childhoods.societies.

Quando o centro Childhoods.Societies foi proposto, "a universidade disse que nós [pesquisadores] só queríamos poucos centros de investigação interdisciplinar", de acordo com o Prof. Sünker. Acrescenta que "este centro foi criado em primeiro lugar por ato do reitor, e, em segundo lugar, nós precisávamos da concordância ou do voto do senado, [que] votou $\operatorname{sim}[\ldots]$ ". Em suas palavras, o centro tem "uma longa lista de membros, mas o desafio é reunir educadores, pedagogos sociais, sociólogos, desportistas, músicos, linguistas, literatos [...] O desafio será continuar com esse trabalho e trazer pessoas para uma cooperação real. ". O centro elabora relatórios bianuais para a reitoria.

O centro foi inaugurado em 2010, com um seminário internacional, para o qual o Prof. Sünker convidou seus "antigos colegas, a começar por Jens Qvortrup, um velho amigo e camarada, Leena Alanen e vários outros da velha geração na Europa". Conta que conheceu estes antigos colegas na "segunda metade dos anos 1980, talvez 1986, eu acho, quando era professor assistente em Bielefeld e era membro do grupo de pesquisa 
'trabalho social, pedagogia social'. Jens e Helmut [Wintersberger] haviam iniciado, no Centro Europeu de Bem-Estar Social, dois projetos: Crianças em risco e Infância como fenômeno social", tendo organizado um congresso internacional no qual o Prof. Sünker apresentou uma comunicação, embora não tivesse trabalhado diretamente com estudos da infância anteriormente. Conta que "concordei [em participar do congresso], porque estava trabalhando com a teoria da educação, a teoria da sociedade, a teoria da criança e do seu bem-estar. E tive sorte, pois no grupo de Bielefeld, tínhamos muito boas relações, relações bem fortes com o escritório de assistência social da criança, da cidade de Bielefeld. Bielefeld é um pouco menor do que Wuppertal [...] O responsável pelo escritório da criança e do bem-estar era um bom amigo de Hans -Uwe Otto, meu melhor colega e amigo em Bielefeld, um dos fundadores da, digamos, crítica ao trabalho social, a pedagogia social na Alemanha. [...] Em seguida, um colega do escritório de bem-estar e eu fomos para a Suécia". O professor informa que havia reclamações a respeito dos trabalhadores da assistência às crianças, porque tiravam as crianças muito rapidamente de suas famílias e um evidente interesse em buscar outras alternativas.

Continua: "meu colega e eu tínhamos um artigo sobre alternativas, sobre, digamos, prevenção e intervenção nos interesses da criança, porque este é um debate - mais uma vez, quase 40 anos depois, temos o mesmo debate -: quando devemos afastar a criança de sua família de origem?" Prof. Sünker posiciona-se: "sou a favor do afastamento dos pais porque meu interesse é a criança. Eu falo sobre crianças e não sobre famílias, [e esta é uma] divisão que se percebe na Alemanha. Na antiga tradição, as crianças são membros das famílias, de modo que todos falam sobre as famílias, mas não sobre as crianças". 
Acrescenta que "acabei por entrar no campo, cada vez mais, porque me interessei pelos projetos europeus. Por exemplo, sou um dos fundadores do comitê de pesquisa da infância ${ }^{79}$ da ISA, embora minha casa na ISA seja outro comitê ${ }^{80}$. [...] Lembro que em 1990, em Madri, começamos com um grupo temático, infância, e que lá estavam todas as pessoas envolvidas com os dois projetos, Crianças em risco e Infância como fenômeno social. E me tornei mais e mais interessado, comecei a publicar livros e artigos. [...] A fundação do centro em Wuppertal é, pode-se dizer, o ponto final, porque em Bielefeld, na Faculdade de Pedagogia, tivemos um então chamado Centro de Pesquisa da Juventude, no início, no meio da década de 80 . Ampliamos o nome para Centro de Pesquisa da Infância e Juventude. O tema infância foi acrescentado principalmente especialmente porque Klaus Hurrelmann estava lá naqueles tempos, estava lá há muito tempo e era o único, na Alemanha, que estava interessado em estudos da infância e da juventude".

Ainda sobre a origem dos estudos da infância em Wuppertal, o Prof. Sünker relata: "um grande grupo, no centro [de Bielefeld], era de colegas jovens, todos professores assistentes, que tiveram de deixar a universidade, para trocar de universidade após a titulação, porque você não pode permanecer como professor contratado na universidade onde conseguiu sua titulação. E, assim, o Centro de Pesquisa da Infância e Juventude em Bielefeld ficou mais ou menos desconhecido. Hoje em dia existem muito poucas pessoas: os membros antigos se foram ou morreram, os jovens membros tiveram que ir para outras universidades [...] Assim, Wuppertal, por acidente, é o único lugar onde algumas pessoas realizam estudos da infância [...] alguns anos depois que

\footnotetext{
${ }^{79}$ RC53 - Sociology of Childhood.

${ }^{80}$ RC10 - Participation, Organizational Democracy and Self-Management.
} 
vim para cá, chegou Doris Bühler-Niederberger. Eu estava na banca quando o trabalho da professora foi selecionado e ela conseguiu o emprego. No início, sem o nome ou o tema da infância, [o centro] era família, educação e socialização. Então, foi por acaso, porque Doris estava fortemente interessada na infância, que começamos a colaboração".

Prof. Sünker se posiciona: "gosto de dizer estudos da infância e não sociologia da infância porque eu não sou sociólogo, embora tenha estudado Sociologia, mas, na velha tradição alemã, estudamos temas muito diferentes".

Questionado sobre o trabalho do centro de pesquisa, Prof. Sünker diz que os pesquisadores "lidam com esse debate alemão, interdisciplinaridade, transdisciplinaridade, multidisciplinaridade e, falando francamente, ninguém sabe claramente o que isso significa". Isto parece não ser um problema ou uma questão a ser discutida, mas praticada. É como um ponto de partida para discutir um tema específico, como explica: "o tema era desvantagem na primeira infância. E abordagem interdisciplinar significa que reunimos a Pedagogia Social, a Pedagogia Escolar, a Teoria da Educação, a Geografia Social, a Linguística", ou seja, a interdisciplinaridade é um princípio metodológico. De acordo com ele, "a abordagem interdisciplinar tenta ainda mediar as diferentes metodologias, os diferentes métodos, as diferentes abordagens, as diferentes perspectivas, porque, eu diria, especialmente em relação aos fatos sociais, às aparências sociais, pode-se ter pontos de vista diferentes sobre o assunto de sua pesquisa. "

Durante a entrevista, o Prof. Sünker enfatiza o problema para obter recursos, uma vez que é necessário apoio do corpo docente para encaminhamento de solicitação à reitoria 
e, só então, torna-se possível a liberação do financiamento para a pesquisa, ou seja, "os pesquisadores do centro têm que submeter [seus projetos] a outras fundações para conseguir dinheiro para conferências internacionais etc.," ou submeter projetos de investigação à União Europeia, como o centro fez, “há dois anos, [...] reunindo diferentes grupos na Europa ${ }^{81}[\ldots]$ para investigação em instituições como jardins de infância ou creches em diferentes níveis". Este projeto não conseguiu financiamento, mas, de acordo com o Prof. Sünker, houve tentativas posteriores, submissão de outros projetos, até que foi obtido financiamento para desenvolver projeto de pesquisa com semelhante dimensão.

Ele aponta o impacto do discurso sobre a política de infância e dos direitos da criança, ou seja, considera esses campos como o caminho para o impacto sobre as práticas e as políticas. Comenta as relações entre a Convenção dos Direitos da Criança (CDC) e os estudos da infância: "o desafio era fazer a mediação entre os novos estudos de infância e o novo discurso sobre a política de infância e dos direitos da criança. Porque convenção da ONU poderia ser interpretada, e estou fazendo isso, como eu disse, como civilizadora no progresso dos interesses das crianças, porque havia um tratamento dos famosos três Ps, proteção, provisão, participação, de uma nova maneira. A antiga visão, tal como a conhecemos, é a proteção em primeiro lugar e a participação ao final. E de acordo com, eu diria, o discurso dominante nos estudos de infância, que significa reconhecer a subjetividade, a competência e a ação infantil, a convenção da ONU argumenta a favor da participação em primeiro lugar. Por isso, prioriza a participação

\footnotetext{
${ }^{81}$ Refere-se ao projeto Growing up succesfully: strengthening the contribution of early years education to combatting disadvantage. As universidades envolvidas eram: Bergische Universität Wuppertal (Alemanha), University of Surrey (Inglaterra), University of Reggio Emilia \& Modena (Italia), University of Ioannina (Grecia) e University of Jyväskylä (Finlandia).
} 
antes da provisão e da proteção, sem negligenciar estes dois. Então, todos esses artigos que tratam do direito de ler os jornais de todo o mundo, de convocar, para demonstrar, para ter um posicionamento próprio, e assim por diante, estão ligados ao que na tradição alemã chamamos bildung, a educação mental e da personalidade integral. Por outro lado, o problema é a abordagem de desenvolvimento na convenção da ONU porque ainda há conversa de seguir os estágios rumo à maturidade. As crianças devem ser autorizadas a fazer isto e aquilo. Esta é a contradição, a tensão na convenção da ONU. Mas a principal diferença no campo das políticas da infância, e que está relacionada a ambos, estudos de infância e direitos da criança, é uma distinção entre política para as crianças e política com as crianças."

E acrescenta: "e, portanto, eu acho que a possibilidade de obter impacto nas práticas e nas políticas é, em primeiro lugar, educar para a nova imagem da criança. Este é o primeiro ponto. Em segundo lugar, para começar os discursos, o que significa fazer política com as crianças e não para as crianças? E o terceiro ponto analítico relevante é superar esta imagem da criança vista somente como dependente, assim, logo de início, argumento [...] [que] em todos os seres humanos há uma dialética especial entre autonomia e dependência, que você carrega ao longo de toda a vida".

Sobre o papel da educação, Prof. Sünker diz: "no pensamento educacional tradicional europeu, há dois pré-requisitos: o primeiro é que todos somos potencialmente razoáveis, o que significa que todos podem desenvolver sua razão. E, em segundo lugar, todo mundo é educável, todos podem ser educados. Então, não há quem seja menos inteligente do que o outro". Para ele, o sistema escolar alemão reproduz a desigualdade social. Ele critica a Pedagogia Escolar, mas acrescenta: "eles [pesquisadores da 
educação] obtêm recursos para a pesquisa. Eles obtêm recursos porque não prejudicam ninguém! E o maior problema é que as pessoas acreditam neles". Para ele, "o livro mais influente na educação, no ensino pós-fascista, é um livro de Adorno, Erziehung zur Mündigkeit. Educação para a maturidade. É difícil traduzir mündigkeit para o inglês, alguns tentaram maturidade e responsabilidade. É a ideia central da teoria da bildung".

\subsubsection{Rita Braches-Chyrek}

Professora de Pedagogia Social na Universidade de Bamberg; uma das fundadoras do centro Childhoods.Societies.

A Profa. Braches-Chyrek se apresenta contando que "antes de ir para Bamberg, estudei em Wuppertal com Heinz Sünker, fiz aqui meus estudos de doutorado, e o campo de pesquisa era crianças. Escrevi sobre crianças que viviam em famílias monoparentais. [...] Atualmente, trabalho na Universidade de Bamberg e meus interesses de pesquisa são Teoria e História do Serviço Social, pesquisa com crianças e com gerações e às vezes também gênero". Relata que o centro de pesquisa tem as crianças como foco e que existem alguns projetos de investigação em andamento, incluindo o seu, sobre infância e famílias adotivas.

Sobre o início do centro, refere a conferência internacional, reforçando que esta primeira atividade teve continuidade com a realização de seminários "a cada semestre, quando pesquisadores de todo o mundo vêm para cá, comentar suas pesquisas". Acrescenta que "o que também é interessante é que trabalham em disciplinas pouco usuais na pesquisa com crianças, por exemplo, o esporte", ou seja, "pensávamos em 
desenvolver conjuntamente a pesquisa, com todas as disciplinas envolvidas, para falar sobre a vida das crianças e das situações das crianças", numa perspectiva interdisciplinar. Questionada sobre esse movimento ser inter ou multidisciplinar, ela responde "multi ... não, interdisciplinar. Acho que é uma palavra melhor. Como o tema principal é a pesquisa com crianças, acho que é uma palavra melhor".

Sobre o impacto acadêmico e político das pesquisas realizadas, a Profa. Braches-Chyrek conta que a equipe de pesquisadores "tem organizado livros com resultados de investigação, nos quais apresentam os resultados. Chegamos a muitas outras pessoas, de fora da nossa comunidade, que leem nossos livros, vêm até nós e querem discutir conosco e fazer mais pesquisas. Esse é um bom caminho, assim como os artigos e os periódicos e assim por diante". Acrescenta que seus colegas "também falam com políticos; participam de fóruns de discussão e outros eventos com políticos, nos quais apresentam nossos resultados e sua discussão, assim como resultados de pesquisa e resultados de debates voltados para a situação das crianças, para que possamos desenvolver alguma coisa".

Aponta, como referencial teórico, "Qvortrup, da Escandinávia, ou Prout e James. No Reino Unido, Jo Moran-Ellis ou Pat Petrie e assim por diante [...], por exemplo, Leena Alanen que traz um conceito geracional muito importante". Sobre os principais conceitos, relata que os investigadores "trabalham também o conceito de agência, e buscam a voz das crianças. Sim, discutimos todos esses conceitos em nosso centro, e alguns pesquisadores preferem o conceito de geração, e outros, o de agência. Sim, discutimos esses pontos, e esperamos nos reunir também no futuro, e que não há como considerar o conceito de geração como o melhor, ou o conceito de agência, também, 
porque acho que é melhor podermos nos conectar com esses conceitos e ter a possibilidade de desenvolvê-los numa pesquisa, por exemplo, na primeira infância ou com crianças mais velhas, e assim por diante. Isso nos dá muitas possibilidades". Acrescenta que os pesquisadores "também discutem os métodos. Em relação a fazer pesquisas com crianças, há alguns pesquisadores famosos na Alemanha, por exemplo, Sabina Andresen, da Universidade de Bielefeld, ou Frederica Heinzel, da Universidade de Kassel, que escrevem livros sobre métodos de pesquisa com crianças. É também uma grande questão na investigação: o que podemos fazer com as crianças em pesquisa? Podemos entrevista-las?".

A Profa. Braches-Chyrek menciona que são cerca de 20 pesquisadores que participam de reuniões, ou seja, "à época em que vêm para nossa universidade. Convidamos os pesquisadores, e, em seguida, ouvimo-los falar sobre sua pesquisa, e depois discutimos". Os colóquios de pesquisa são realizados desde 2007. O centro publicou um livro, "Infância e Sociedade [...], neste momento, estamos trabalhando no segundo livro [...] Provavelmente, Infância e Espaço, mas não temos certeza ainda".

Segundo ela, "No centro de pesquisa, os pesquisadores têm os seus próprios tópicos de investigação. Heinz [Sünker], por exemplo, escreve bastante e tem muitos ensaios sobre infância e sociedade e políticas e direitos da infância, por exemplo, e este é o seu tema principal neste centro de pesquisa. O tema políticas e direitos da infância permite que ele fale em muitos campos com os políticos, para mudar a situação para as crianças". Diz ainda que "acho que é muito importante que você fale sobre os resultados da investigação vindos de outros países. Porque eles têm, por vezes, uma outra visão sobre a situação da infância ou das políticas para a infância e assim por diante, e eu acho que 
é uma possibilidade muito boa para desenvolver as ideias sobre a infância e situações, e, sim, para desenvolvê-las. [...] por exemplo, quando você pensa sobre os direitos das crianças, quando você dá uma olhada em outros condados, você pode ver que eles têm uma outra visão sobre os direitos da infância."

Ela finaliza sua fala contando que "na Alemanha temos diferentes disciplinas que têm uma visão sobre a pesquisa da infância. Temos algumas pesquisas na Psicologia, mas elas têm a sua própria visão, suas próprias teorias. Nós temos, de outro lado, a Pedagogia Social, com suas próprias teorias e métodos [...], e, por outro lado, a Sociologia, também com suas próprias teorias e métodos de investigação [...], e às vezes diferentes da Pedagogia Social, da Pedagogia para todos, para a escola [...] Nós temos dois tipos de universidade. Temos a universidade ${ }^{82}$ como esta em que você está e as universidades aplicadas ${ }^{83}$. Nas escolas superiores de ciências aplicadas, temos, nos últimos anos, o desenvolvimento de seus próprios estudos da infância; Pedagogia da Infância. [...] Você pode estudar lá para aprender sobre o jardim de infância. É uma proposição em andamento na Europa e, na Alemanha, estamos um pouco atrasados. Em algumas dessas universidades aplicadas, eles fazem suas próprias pesquisas em alguns campos, no campo da primeira infância, por exemplo. É, neste momento, muito interessante, porque as diferentes disciplinas não trabalham juntas, mas sim trabalham cada uma para si. [...] Acho que é importante que você conheça as teorias das outras disciplinas".

\footnotetext{
${ }^{82} \mathrm{Na}$ Alemanha, as universidades clássicas dedicam-se exclusivamente à ciência pura e oferecem um grande o leque de cursos, sendo habilitadas a conferir o grau de doutor.

${ }^{83}$ Ao lado das universidades técnicas, as escolas superiores de ciências aplicadas promovem o ingresso mais rápido na profissão e uma formação mais voltada para a prática, embora também admitam a pesquisa. (Informação disponível em http://www.tatsachen-ueber-deutschland.de/pt/ensino-eciencia/main-content-07/a-diversidade-do-sistema-de-ensino-superior.html, acesso em setembro/2014)
} 


\subsubsection{Anneta Potsi}

Faculdade de Ciências da Educação/Escola de Pesquisa em Educação e Capacidades, da Universidade de Bielefeld. Professora visitante, em pós-doutorado.

A Profa. Potsi inicia a entrevista se apresentando: “Meu nome é Antoanneta Potsi. Sou educadora da primeira infância. Terminei recentemente o meu doutorado na Alemanha, em Bielefeld e na Universidade de Dortmund. Desde 2012, tenho trabalhado com Heinz [Sünker] aqui em Wuppertal. Eu estou fazendo pesquisa em educação infantil. Minha área de interesse é o discurso da escolarização da primeira infância, o novo discurso dos estudos de infância, e o discurso do desenvolvimento, que é o dominante hoje em dia. Acho que é muito interessante que o discurso dos novos estudos da infância traga temas como gênero e desigualdade, discussões no campo da Educação Infantil, que não são dominantes, contra o discurso do desenvolvimento."

Conta que é grega e que sua pesquisa é sobre crianças vivendo em crise social. Explica que "há pouco tempo, como disse a você, eu vim da Grécia. Recentemente, e eu não sei se você está ciente, a Grécia tem enfrentado o enorme impacto da crise financeira. As crianças têm sido vítimas dessas circunstâncias. Minha pesquisa trata de como a crise social tem impactado as crianças". Para ela, política e pesquisa estão interligadas. Ela relata: "Se você tomar, por exemplo, a União Europeia, que financia atividades de investigação, e, mais ou menos, define quais as pesquisas que serão realizadas nas universidades. Além disso, obtém feedback das universidades onde as pesquisas foram feitas a fim de identificar novas áreas de atividades de investigação para o futuro. De acordo com a perspectiva da criança sendo e não somente se tornando, estamos nos 
movendo rumo a um estágio em que [essa condição] seja amplamente reconhecida. [...] Está também interligado ao fato de que, hoje em dia, os jovens, especialmente na Europa, têm uma postura de não interferir nas políticas oficiais. [...] Acho que se tornou uma questão [o fato de] que as crianças e os jovens entram na arena de serem considerados cidadãos".

A Profa. Potsi está trabalhando com "os textos de Heinz Sünker e Jo [Moran-Ellis], [Jens] Qvortrup. Eles são os principais discursos. Além disso, Elder ${ }^{84}$ (Crianças da Grande Depressão) fez pesquisa sobre crianças agentes (being) em crise social. Acho que foi durante o período da crise antes da Segunda Guerra Mundial nos EUA. Ele escreveu um livro muito interessante sobre as crianças que cresceram nesse período. Eu também uso como referência."

Para ela, o centro é interdisciplinar: "da minha experiência menor, porque não tenho tanto tempo envolvida com o centro, acho que há uma colaboração interdisciplinar entre os membros. [...] Nas reuniões que temos juntos, há um debate contínuo a fim de trazer diferentes discursos sobre o mesmo tema e aproximá-los, porque todos nós estamos lidando com a infância. Acho que funciona na direção da interdisciplinaridade. Quando sou pesquisador em um campo específico, é realmente difícil tornar-me mais próximo de outras disciplinas e trabalhar em conjunto. Penso que o limiar ou as margens entre a multidisciplinaridade e interdisciplinaridade são realmente flexíveis". Exemplifica: "Estamos também lidando com este apelo da União Europeia: o jovem como [pro]motor da mudança social. Adicionamos um economista político e uma pessoa que está lidando com questões religiosas e gerontologia, a fim de ver as diferenças entre

\footnotetext{
${ }^{84}$ Glen H. ELDER. Children of the Great Depression, 1974.
} 
as gerações. Eu acho que há uma tendência e uma ênfase nessa direção, mas é realmente difícil. Em todas as reuniões, temos dificuldade em nos compreender um ao outro e chegar a um ponto comum".

Segundo ela, o financiamento para essas reuniões "não é um problema, porque o Ministério da Educação para a Renânia do Norte-Vestfália ${ }^{85}$ prevê o financiamento para trazer outros pesquisadores, promover reuniões e trabalhar em conjunto, a fim de produzir uma boa proposta a apresentar à UE. Naturalmente, o retorno para o Estado é conseguir um projeto de dois milhões de euros".

Sobre educação, ela diz que "o discurso dos novos estudos da infância está ganhando espaço progressivamente, pelo menos na Europa, e acho que a ênfase deve ser dada principalmente para faculdades e departamentos de educação. Se você conseguir sensibilizar os educadores e quem os torna ciente de todos os parâmetros e das questões que eles precisam levar em conta, acho que vai ganhar terreno, a fim de promover e difundir o ponto de vista dos novos estudos da infância. [...] Acho que é fácil para os europeus, e especialmente para os europeus do Norte, como alemães, discutir e promover essas ideias, porque a falta de recursos é o principal problema para lidar com questões como a desigualdade e as diferenças no campo da educação infantil. Acho que vai ser mais difícil para o meu país, a Grécia, mas também, acho, para você igualmente, promover essas ideias num nível político devido à falta de financiamento e os recursos escassos."

\footnotetext{
${ }^{85}$ Estado alemão onde está situada a cidade de Wuppertal.
} 
Para terminar, a Profa. Potsi afirma: "Acho que não estamos levando em conta a pluralidade de infâncias que estão ocorrendo hoje em dia. Vivemos num mundo globalizado, mas 'infância' não o é. Estamos falando de infâncias. É claro, deve haver uma tal pluralidade, e deve ser dado espaço para estas infâncias se desenvolverem de acordo no futuro. Penso que esta é a parte enganosa e o maior dano provocado pelo discurso da infância da Psicologia do Desenvolvimento. Ela promove um modelo básico. Ela normaliza a infância, e quem não consegue estar de acordo está excluído".

\subsubsection{Norwegian Centre for Child Research (NOSEB) ${ }^{86}$, Norwegian University of Science and Technology (NTNU), Norway}

Localizado em Trondheim, o NOSEB ${ }^{87}$, desde 1982, realiza pesquisa sobre a infância e sobre as atividades e as condições de vida das crianças, numa perspectiva interdisciplinar. Publica, em colaboração com a Sage Publications, a revista Childhood (Infância), referência internacional no idioma inglês. Além de pesquisadores locais, o centro reúne pesquisadores da infância de renome internacional e enfatiza a pesquisa interdisciplinar, incluindo Geografia, Antropologia Social, Sociologia, História e Pedagogia. Segundo o site, a pesquisa está relacionada com três prioridades temáticas: institucionalização da vida das crianças no interior do estado de bem-estar moderno; os direitos das crianças numa perspectiva global; as crianças como consumidoras.

O NOSEB ocupa um conjunto de salas no piso térreo do edifício do Instituto de Educação.

O espaço inclui salas para os pesquisadores, uma pequena biblioteca, sala de reuniões

\footnotetext{
${ }^{86}$ http://www.ntnu.edu/noseb

${ }^{87}$ Norsk Senter for Barneforskning.
} 
e, ao fundo, uma grande mesa usada para refeições e reuniões. Na entrada, à esquerda, há uma coleção do periódico Childhood, para fácil acesso.

Neste centro interdisciplinar, entrevistei Vebjørg Tingstad, sua atual diretora, Anne Trine Kjørholt, pesquisadora, diretora do centro por 12 anos e atual vice-reitora da NTNU. Aproveitei a oportunidade para ir a Oslo e entrevistar também o prof. Jens Qvortrup.

\subsubsection{Vebjørg Tingstad}

Diretora do NOSEB, pesquisadora das relações entre crianças e mídia, entre elas e a internet.

A Profa. Tingstad é mestre em educação infantil e seu doutorado tem como tema o batepapo infantil na Internet. Ela conta seu percurso no NOSEB: "Comecei no centro quando era estudante de mestrado, originalmente era professora da pré-escola, [...] foi um tipo de seleção para ser assistente, assistente de pesquisa, por exemplo, de Anne Trine e de outro pesquisador em dois projetos diferentes. [...] Então estava envolvida em diversos projetos até que, três anos depois, obtive financiamento no doutorado para fazer um estudo sobre a mídia". Em sua pesquisa, entrevistou crianças sobre seu uso da internet, "quer dizer, isso tem sido a pedra fundamental no edifício, no centro de seu início, o princípio de perguntar às crianças". E acrescenta "sei que você conhece a história dos estudos da infância paralela a esta. Tivemos colaboração entre antropólogos e sociólogos que tiveram esse objetivo ambicioso de introduzir um novo paradigma nos estudos da infância. [...] Assim, esta foi a minha atitude, a abordagem do meu doutorado 
também. Depois do doutorado, fiz um pós-doc relacionando a internet ao consumo" . As crianças como consumidores são seu interesse: "depois do pós-doutorado, submeti projeto ao Conselho de Pesquisa da Noruega, juntamente com David Buckingham, acerca de consumo, as crianças e o consumo", uma pesquisa prevista para três anos.

Ela menciona que o paradigma dos estudos da infância (James \& Prout, 1990) "não é $100 \%$ consenso [entre os pesquisadores], [...] nós temos discussões o tempo todo sobre agência e estrutura [...] talvez possa ser da Antropologia a tradição que focaliza mais a agência descritiva, agora pensada em termos muito mais amplos. [...] Mas, enquanto isso, alguns sociólogos costumavam olhar para a sociedade em termos mais estruturais, [...] nós nunca finalizamos essa discussão". E reforça: "quer dizer, essa é uma questão que Jens Qvortrup, um dos fundadores da nova Sociologia na Infância, destaca firmemente, que você não pode olhar para a infância independentemente da sociedade. Quer dizer, a infância é uma categoria social [...] Pode parecer óbvio, mas quando temos essas discussões não parece tão óbvio". No entanto, "compartilhamos as principais questões do paradigma, que é importante olhar para a infância no contexto". Conclui, dizendo que "acho que o principal, a história principal de NOSEB, é que agência e estrutura têm o mesmo peso, além de que precisamos entrevistar as crianças de forma simples e desenvolver bons métodos para fazer pesquisa com crianças e com a infância". Sobre o impacto acadêmico do centro, ela considera os efeitos causados nos estudantes ao concluírem seus estudos, constatando que mudaram. Quanto ao impacto político, diz que "quando solicitamos financiamento [para pesquisa], esperamos contribuir com a importância social, com a relevância para a sociedade". 
A Profa. Tingstad conta a história do NOSEB: "que era um centro localizado fora da universidade; foi avaliado no final dos anos 1990 e a avaliação concluiu que a pesquisa era pouco abrangente, de forma que foi incluído na universidade, mas como um centro autônomo. Assim, nunca fomos parte de um instituto. Pode ser [que isso aconteça] a partir do próximo ano, porque as faculdades estão sendo avaliadas agora para ver se o número de institutos deve ser limitado, mas, até agora, o NOSEB não faz parte de um instituto, mesmo estando [localizado] no mesmo prédio do Instituto de Educação, no momento". Acrescenta que "não é no Instituto de Educação que encontramos os colaboradores mais interessantes, mas na Geografia, na Antropologia e na Sociologia. Eles são mais próximos ao modo pelo qual vemos a sociedade".

A diretora conclui dizendo: "Eu Ihe disse o que nós éramos, via de regra explorando a estrutura dos institutos. Quando se trata do modelo de centro, acho, não sei como é em outros lugares do mundo, mas parece que estamos em grande sintonia com muitas outras visões na universidade. E uma das visões é [a produção de] o conhecimento para um mundo melhor [...]. Se a tomarmos seriamente, esta visão é sobre a globalização, é sobre a internacionalização, é sobre estabelecer ou manter estruturas que possam incentivar essa visão. Portanto, esta é a batalha que temos localmente agora, é... são as estruturas daqui compatíveis com as grandes questões? E quero dizer que sentimos que, e conversando tanto com Allison James quanto com David Buckingham sobre como é no Reino Unido, as formas com as quais temos abordado a pesquisa da infância não são aquelas que são necessariamente incentivadas economicamente hoje [...] porque há outras coisas que são financiadas. E podemos ver aqui [que a pesquisa] é mais baseada em evidências, é mais tradicional, é mais investigação baseada em testes que são... Mas 
espero que isso possa virar ao contrário novamente. Esperamos? Assim, a ideia e o imperativo de ter pesquisa interdisciplinar frente a alguns desafios hoje na sociedade de pesquisa, no sistema de financiamento".

\subsubsection{Anne Trine Kjørholt}

Pesquisadora, diretora do NOSEB por 12 anos e Vice-Reitora de Pesquisa da NTNU

A Profa. Kjørholt começa contando que trabalha como pesquisadora do centro desde 1989. Antes de se tornar diretora, trabalhou em diversos projetos, "avaliando e fazendo supervisão e fazendo apresentações para os elaboradores de políticas, para pessoas do município, para pessoas do condado e assim por diante, em diferentes áreas". Foi professora da educação infantil, fez seu mestrado em Antropologia Social e seu doutorado, em Educação, "foi sobre o direito de participação das crianças, as crianças como atores sociais na sociedade. Foi uma investigação crítica dos discursos globais sobre os direitos das crianças, o direito à participação em particular, conectado a estudos empíricos de variados projetos de participação desenvolvidos na Noruega por elaboradores de políticas de diferentes tipos. Utilizei isso [os estudos] como material empírico".

Ela diz que: "depois do meu doutorado, continuei com o desenvolvimento de pesquisas externas submetidas e financiadas pelo Conselho de Pesquisa norueguês [...] várias ideias, várias submissões que se sucederam, e que eram um tipo de ligação [...] ao meu doutorado, de alguma forma". Atuou em mais de um grande projeto de pesquisa, em

colaboração com o Departamento de Sociologia, às vezes ligado ao Childwatch 
International $^{88}$. Conta que sua pesquisa até 2005 foi, basicamente, na Noruega. "Mas, então, depois disso, eu tenho me envolvido com projetos de investigação na África". Trabalhando com colaboradores locais, desenvolveu pesquisa "sobre o impacto das sociedades ocidentais modernas e a infância ideal e as chamadas noções de boa infância desenvolvidas na Europa do Norte em um momento particular da história, e que não é necessariamente compatível com as infâncias e as vidas cotidianas das crianças em diferentes partes do mundo fora da Europa".

Sobre o centro, a Profa. Kjørholt relata que "quando assumi como diretora do centro, ele era muito pequeno, pois tinha apenas dois postos de trabalho permanentes, dois professores e um funcionário administrativo ... um staff administrativo, portanto, muito pequeno. Jens Qvortrup tinha deixado algum recurso, o que me deu espaço para a construção de uma estratégia. [...] Antes, no centro, quando estávamos fora da universidade, só fazíamos pesquisa. Quando nos tornamos parte da universidade, tivemos que nos adaptar ao reitor e à estrutura da universidade, e isto requeria e demandava a mim e ao centro o desenvolvimento de aulas, de programas educacionais. Então, naquela época, uma das coisas que tive como tarefa, em 2002: primeiro criamos dois cursos e, mais tarde, um programa de mestrado internacional. Decidi que seria internacional porque havia falta de programas internacionais de mestrado na nossa faculdade e era o que se desejava, e temos... tivemos uma rede internacional, uma ampla rede de pesquisa".

Ela continua: "a outra coisa que eu fiz, porque éramos tão poucos, era realmente muito estranho que fossemos estabelecidos como um departamento, com tão poucas pessoas.

\footnotetext{
${ }^{88}$ http://www.childwatch.uio.no/
} 
[...] Outra [estratégia] foi contratar um professor, um professor internacional também para fortalecer. Então, naquela época, éramos muito especiais, comparados com os outros departamentos, porque tínhamos dois postos de trabalho permanentes e cinco professores afiliados, parte dos melhores especialistas internacionais, como Allison James, David Buckingham, Chris Jenks, Stuart Aitken, e, mais tarde, Jens [Qvortrup], quando assumiu como professor de Sociologia". Diz que os especialistas "desenvolveram um tipo de espaço onde eu lhes dava muita liberdade, a cada um deles e a todos, para trazerem ideias criativas sobre como poderiam organizar workshops, seminários internacionais, produzir publicações, porque para a nossa universidade e nossa faculdade é muito importante produzir publicações, que são contabilizadas e obtemos o financiamento básico com base no que produzimos, em termos de publicações, em relação ao financiamento externo, em relação aos alunos que orientamos e produzem". Buscou conectar os pesquisadores externos aos dois internos para que trabalhassem em colaboração.

Foi coordenadora de "um projeto da UE, uma ação da $\operatorname{COST}^{89}$, sobre o bem-estar das crianças, por iniciativa de Jens [Qvortrup] e Ann-Magritt [Jensen] que desenvolveram o projeto, e Ann-Magritt começou a coordená-lo. E então eles me pediram para assumir. Eram 24 países em desenvolvimento ou não, mas 24 países diferentes na Europa, que participaram e [a pesquisa] era sobre o bem-estar das crianças".

Questionada sobre a interdisciplinaridade, ela disse: "o caráter interdisciplinar dos estudos sociais das crianças e da infância, para compreender a vida das crianças, seu desenvolvimento, sua educação, conectadas a diferentes contextos culturais e às

\footnotetext{
${ }^{89}$ European Cooperation in the field of Scientific and Technical Research (COST). <http://www.cost.eu/>
} 
diferenças de tempo e espaço, é o que é atraente para mim, como pesquisadora". E acrescenta: "trabalhei no centro, com o primeiro diretor, Per Egil Mjaavatn, que não tinha uma abordagem teórica. Assim, foi quando Jens [Qvortrup] chegou como diretor do centro, acho que foi em 1999, que, em seguida, fui apresentada a este paradigma teórico, que acho que foi muito estimulante e inspirador porque me faz pensar, obter conhecimento e investigar como as vidas das crianças diferem no tempo e no espaço. $O$ conceito principal, alguns dos conceitos-chave em perspectivas teóricas, como a agência das crianças, as crianças como atores sociais e as perspectivas das crianças, outras perspectivas da criança em pesquisa, que se tornaram muito atraentes para mim".

A Profa. Kjørholt admite que, depois de todos esses anos, está mais crítica em relação aos estudos da infância porque "se você quiser fazer pesquisa e investigar a perspectiva das crianças, [...] eu acho que é importante, mas por outro lado eu acho que é preciso tempo para entender um grupo de perspectivas das pessoas. Você tem que fazer observações participantes. "

Conclui, ponderando que "Jens fala sobre estrutura. E enfatiza a estrutura social e econômica, a fim de entender as pessoas. Eu fui inspirada pelo conceito de discurso, que é pós-estruturalista. [...] Não sou uma pós-estruturalista muito radical [...] porque eles dizem que tudo é flutuante, tudo é flexível. [...] Tenho me pautado por um pesquisador, antropólogo, que diz que o discurso é uma espécie de substituto do conceito de estrutura e de agência, como dois tipos de coisas diferentes". Nesse sentido, "o discurso é uma forma de substituir o conceito da cultura, é muito amplo. Isso significa que, se você estiver indo investigar as perspectivas das crianças e interpretar as suas vozes, você tem que olhar para a cultura, para o contexto político, a fim de compreender a sua voz. 
Portanto, é ver a dinâmica. Então, às vezes, a agência das crianças, as crianças como atores, não estão sendo interpretadas em relação a sua [cultura], de modo que é a minha maneira de contribuir para as teorias".

Sobre o impacto da pesquisa em ambientes políticos, comenta que foi convidada para um estudo sobre a questão e verificou que não existem estudos sobre isso. Está atualmente trabalhando em um artigo sobre o impacto da pesquisa sobre os direitos das crianças na Noruega.

\subsubsection{Jens Qvortrup 90}

Sociólogo, um dos fundadores do campo da Sociologia da Infância e ex-diretor do NOSEB. É atualmente professor emérito da NTNU.

A entrevista foi iniciada com uma questão sobre o papel da Sociologia da Infância nos estudos da infância. O Prof. Qvortrup diz: "as diferentes disciplinas têm suas ideias sobre como estudar as crianças e a infância. [...] Quando comecei a pensar sobre Sociologia da Infância, isso estava na base de algumas observações que fiz na companhia de sociólogos da família. Eles não estavam tão interessados em crianças, tampouco na família e ou nos pais, mas sim na infância. E por isso me ocorreu que você deve ser capaz de saber qual o papel que a Sociologia poderia ter no trato com as crianças, na medida em que as crianças realmente são seres humanos e, portanto, também devem ser

\footnotetext{
90 Devo dizer que, estando na Noruega para conhecer e entrevistar pesquisadores do NOSEB, considerei fundamental entrevistar o Prof. Qvortrup, em razão de sua importância no campo da Sociologia da Infância. Foi ele quem mediou o contato com as profas. Tingstad e Kjørholt, apesar de aposentado. Vive em Oslo e, generosamente, como é seu estilo, concedeu-me a entrevista.
} 
incluídas na área de Sociologia ". Acrescenta: "Então, o grande problema era: Como você usa exatamente Sociologia e os métodos e metodologia da Sociologia e os instrumentos de pesquisa da Sociologia, e assim por diante, para estudar as crianças ou a infância? [...] Eu venho de uma posição marxista e estrutural, tinha sido interessado em desigualdade social e em política social e de bem-estar [...] Eu já tinha uma perspectiva estrutural [...] Só estava utilizando, em princípio, as mesmas perspectivas e instrumentos de quando estava estudando outras pessoas, de várias maneiras. E então não foi uma ruptura, foi simplesmente dirigir a perspectiva estrutural para as crianças e a infância".

Ele conta que, em relação às primeiras investigações, "conversei com pessoas que estavam interessadas em outras coisas e em família e assim por diante, mas quem também tentava compreender as perspectivas [da mesma maneira] e então tivemos sorte o suficiente para criar um projeto, à época, no qual poderíamos tentar usar essas ideias e em que, por exemplo, uma perspectiva estrutural neste contexto significasse uma perspectiva geracional e não uma perspectiva de classe, e não uma perspectiva de gênero, e assim por diante, mas, na verdade, uma perspectiva que lidasse com geração. Isso foi muito importante, ter essa ideia, porque ela nos ajudou na formulação de novas ideias sobre isso. [...] A dificuldade era que havia muito poucos sociólogos que tinham a mesma experiência e apenas eventualmente eu ficava sabendo de outras pessoas aqui e ali, e elas eram Barry Thorne e [William] Corsaro e [Allison] James, que estavam interessadas, mas, é claro, nós éramos diferentes também. Quero dizer, Allison James e eu tivemos uma série de discussões, mas a questão é definir quais são os determinantes estruturais ao falar sobre a infância [...] e muitas pessoas não costumam combinar as 
crianças com estes grandes macrofatores. E acho que esse é um grande problema [...] que acho que está se tornando mais e mais grave hoje em dia, porque mais e mais pessoas estão se voltando para [o que] eles chamam de Sociologia da Infância, como você diz, mas de fato eles estão se voltando agora para uma perspectiva micro".

Neste sentido, ele distingue estudos em pequena escala, acerca de crianças brincando aqui e ali, por exemplo, e os estudos em grande escala, como escolarização: "a escolarização é algo que pertence ao campo macro no mundo e as crianças também são importantes lá. E há, claro, muitas maneiras nas quais as crianças são atores em grande escala, economicamente e historicamente, [por exemplo] trabalho infantil e trabalho das crianças [...] Barry Mayall e Virginia Morrow recentemente escreveram um livro sobre o trabalho infantil durante a Segunda Guerra Mundial ${ }^{91}[. .$.$] todos nós vemos que$ as crianças têm um papel no mundo da guerra, enquanto os adultos estão fazendo outra coisa, seus pais estão nos campos de batalha e suas mães assumem o trabalho dos pais. [...] Este tipo de perspectiva é importante porque não basta simplesmente dizer que elas têm agência, mas esta deve ser combinada com uma perspectiva mais ampla".

Sobre o NOSEB, ele conta: "vim para o NOSEB em 1999, e o líder era um pedagogo, cujo nome é Per Egil Mjaavatn [...], mas ele era como um administrador, não parecia muito interessado em teoria e queria fazer estudos em pequena escala sobre as crianças, se elas apresentavam algum problema. [...] Ele, de certa forma, foi muito bem-sucedido, porque conseguiu obter dinheiro, e também foi útil para estabelecer as bases para a revista Childhood". Prof. Qvortrup continua: "devo dizer que não sou um bom administrador e acho que estava tentando pressionar por novas perspectivas, por

\footnotetext{
${ }^{91}$ Mayall e Morrow, 2011.
} 
pessoas para trabalhar no doutorado e para dar um novo começo para o NOSEB. Mas também devo dizer que havia muitos problemas no financiamento e houve discussões entre o Conselho de Ciências Sociais em Oslo e a Faculdade em Trondheim. E, depois de três anos, eu decidi parar porque não gostava de utilizar todo o meu tempo em embates, e poderia trocar meu emprego para professor do Instituto, ou do Departamento de Sociologia, e foi assim que terminou. Então veio Anne Trine e assumiu a direção e continuou esse trabalho". Completa: "Então continuei meu trabalho com a infância, em parte juntamente com Ann [Magritt Jensen], que também estava interessada, a partir de um ponto de vista demográfico, mas tínhamos começado um novo projeto, e este foi realmente algo que começamos enquanto eu era o diretor do NOSEB, o chamado projeto COST, uma continuação do projeto Infância como um fenômeno social".

Questionado sobre o impacto da pesquisa, ele dá um exemplo: "essa expressão seres humanos e devires humanos ${ }^{92}$, por exemplo, que aconteceu de eu formular há muitos anos, mesmo sem saber realmente qual era o significado. [...] Depois, muitos anos mais tarde, talvez três ou quatro anos atrás, eu recebi um email de Judith Ennew que dizia “não consigo resistir a enviar isso para você porque veio das Nações Unidas: eles lá estão usando essa frase, human beings... human becomings..." E continua: "ao mesmo tempo, ou mais ou menos ao mesmo tempo, eu encontrei em um jornal local em Trondheim, um artigo escrito por alguém de lá, que disse 'bem, agora na Grã-Bretanha, eles estão falando agora mais e mais sobre human beings... human becomings [...] O fato de você

\footnotetext{
${ }^{92}$ Prof. Qvortrup refere a expressão em artigo recente (2009a), publicado na Itália. Para compreender a extensão, o peso da expressão, vou manter a citação em inglês: "children are not human beings but human becomings has become standard since it was first formulated (Qvortrup, 1985), but now lives its own fatherless life as exactly a succinct expression, yesterday in an official UN-publication, today in a provincial Norwegian newspaper ..."
} 
ter um artigo de jornal numa cidade norueguesa e formulações em Nova York, nas Nações Unidas, usando as mesmas palavras, torna este exemplo curioso".

Sobre a pesquisa interdisciplinar, o Prof. Qvortrup comenta que estudiosos de diferentes áreas "podem, ao menos, chegar a um entendimento e torna-lo proveitoso para trabalhar em conjunto, o que acontece com os denominadores comuns aqui que permitem falar em pesquisa multidisciplinar, tanto focalizando a criança individual quanto a infraestrutura da infância... E eu acho que ela pode muito bem ser proveitosa e útil, mas é necessário trabalhar arduamente para encontrar as características comuns dessas disciplinas, e, nesse sentido, acho possível trabalhar juntos [...] não é uma contradição disciplinas ou conhecimento não se contradizerem mutuamente; deve ser possível trabalhar em conjunto, mas deve-se haver consciência das dificuldades em trabalhar em conjunto". Completa: "quero dizer que são relações de poder postas na pesquisa [...]. A cooperação, penso eu, pressupõe uma espécie de força igual”.

\subsubsection{Centre for the Study of Childhood and Youth (CSCY) ${ }^{93}$, University of Sheffield, UK}

Em operação desde janeiro de 2002, este centro interdisciplinar inclui membros de diversos departamentos e tem várias parcerias internacionais, o que gera investigação em colaboração sobre questões teóricas e empíricas. Reúne pesquisadores da Sociologia, da Educação, do Direito, da Saúde, do Serviço Social, da Arquitetura, da Psicologia, da Geografia, da Enfermagem e Obstetrícia, das Ciências da Comunicação, da Odontologia e da Música. De acordo com sua página, há sete grupos de interesse de

\footnotetext{
${ }^{93} \mathrm{http}: / /$ cscy.group.shef.ac.uk/
} 
pesquisa: Crianças e relações intergeracionais; Espaços e lugares das crianças; Infâncias globais; Grupo de pesquisa visual; Saúde do corpo e bem-estar; Crianças e famílias vulneráveis: Promovendo a resiliência; Deficiência@UOS. O centro publica o periódico Childhoods Today, uma revista eletrônica bianual, desde 2007.

Dirigido por Allison James e por Penny Curtis, o CSCY não tem um lugar específico: as entrevistas foram feitas nos departamentos nos quais as pesquisadoras trabalham.

No centro, entrevistei Alisson James, uma das duas diretoras, Dylan Yamada-Rice, coordenadora do mestrado em Educação, e Afua Twum-Danso Imoh, docente e corresponsável pelo periódico Childhoods Today. Não havia pesquisadores-visitantes no período em que as entrevistas foram realizadas.

\subsubsection{Allison James}

Departamento de Estudos Sociológicos, uma das diretoras do CSCY

A Profa. James conta que o CSCY "foi fundado em 2002 por Alan France e Derek Armstrong. Alan France estava aqui no Departamento de Estudos Sociológicos e Derek estava na Educação. Por isso, foi concebido como um centro interdisciplinar. E eles foram acrescentando acho que cerca de dez outros departamentos. Incluindo Paisagismo, Arquitetura, Direito, Política, Geografia, Saúde, não me lembro de todos agora, mas um grande número de departamentos. Cheguei em 2003 e o centro tem crescido desde então, e cresceu como centro interdisciplinar, e para mim isso é muito importante, ainda que talvez só tenhamos... só temos uma pessoa da Música e uma da Religião. Não obstante o fato de serem membros do centro, é importante para mim 
porque sentimos que todos nós nos beneficiamos ouvindo outros pontos de vista sobre o que fazemos. Por isso, começou como um centro interdisciplinar e continua dessa maneira. Eu sinto que isso é muito, muito, muito importante para o centro, porque significa que aprendemos uns com os outros, de uma forma muito produtiva". O CSCY tem reconhecimento oficial da Universidade como um dos seus centros de pesquisa e apresenta relatórios ao Diretor de Pesquisa da Faculdade.

Ela explica que os diretores "têm tentado várias maneiras de organizar o centro ao longo dos anos, mas porque todo mundo está muito ocupado, porque o centro não é um departamento, e todos são membros de um departamento em primeiro lugar, que é onde têm os seus alunos, onde dão aulas, a adesão ao centro é um pouco como um hobby, de fato! Assim, torna-se bastante difícil para as pessoas se encontrarem mais frequentemente. Dessa forma, há cerca de dois anos atrás, nós nos organizamos em grupos de interesse de pesquisa. Portanto, há um grupo estratégico que corre o centro, que garante que o programa de atividades aconteça, que lida com o periódico, que busca financiamento e tudo isso, e depois há estes grupos de interesse de pesquisa, que são formados em torno dos interesses das pessoas. E estas podem participar de um ou, dois ou três grupos de pesquisa, ou podem também ser membros do corpo central do centro. Portanto, há flexibilidade no modo de participar. Mas cada um desses grupos de interesse de pesquisa também é interdisciplinar [...] e eles têm surgido porque as pessoas e os grupos de pessoas dentro do centro estão interessados em um tópico em particular. [...] Acho que é uma estrutura que funciona muito bem, uma vez que não somos um centro financiado em qualquer sentido". 
Sobre o financiamento, a Profa. James conta que a universidade paga para Dawn [Lessels], “que é a nossa funcionária administrativa, em tempo parcial. Houve um pequeno problema, que eu não vou me deter, mas que nos manteve em movimento. $E$, recentemente, nós ganhamos também algum dinheiro para ter um pesquisador pós-doc por um ano, e um gerente de desenvolvimento de pesquisa, mas este, só neste último ano. Então esse é o financiamento de base que temos. Então, se as pessoas fazem pesquisa, elas solicitam individualmente para seu financiador e recebem financiamento para fazer suas pesquisas. O único recurso financeiro obtido pelo centro é o lucro que nós conseguimos em nossa conferência internacional ou a taxa que cobramos em nossas oficinas. Assim, não obtemos lucro com as oficinas, mas elas cobrem seus custos, de modo que, se convidamos um palestrante externo, vamos cobrar $£ 10, £ 15$ para cobrir o almoço das pessoas. [...] Então é assim que fazemos".

Quando perguntada sobre o impacto acadêmico do CSCY, reconhece que não há pesquisa sobre o que supõe, mas acha que estudar as crianças é tarefa difícil e solitária para os estudantes interessados. Assim "nesse sentido muito pessoal, mesmo discutindo métodos ou discutindo ética ou discutindo a dificuldade de fazer pesquisas com crianças ou os prazeres disso ou... o tipo de ambiente de apoio, acho que tem impacto para o estudante; se ele tem qualquer impacto maior, eu não sei. Mas espero que nós estejamos alimentando a próxima geração de pesquisadores da infância. $E$ acho que sempre recebemos e-mails muito gentis de pessoas que dizem que se beneficiaram ao vir para os nossos eventos, e isso é muito bom". 
Por outro lado, em relação ao impacto político, ela menciona projetos realizados com hospitais infantis: "gosto da ideia de que parte do trabalho que faço é muito prático, tanto quanto algumas das pesquisas. Assim, algum tempo atrás fizemos alguma pesquisa sobre os hospitais infantis, muito prática, que foi muito agradável e eu realmente gostei de fazer. Trabalhamos com arquitetos e com o hospital e temos um outro projeto com o hospital, em torno de questões muito práticas. O primeiro focalizava o design de interiores dos hospitais e a ideia de ambientes amigos das crianças. Nossa pesquisa mostrou que, na verdade, a maioria das crianças com mais de sete anos de idade os acham muito infantis, para bebês. Elas não gostam dos hospitais. [...] E esse projeto que estamos fazendo agora focaliza a ideia de cuidado centrado na família".

Falando sobre a teoria em estudos da infância, ela refere-se ao seu último livro, publicado em dezembro de 2013, que "está tentando aproximar esse tipo de estudo muito detalhado das vidas cotidianas das crianças ao arcabouço teórico que tentei construir". Explica que "as crianças não são grupos, as crianças são indivíduos, e o que este livro faz é tentar mostrar a individualidade das crianças como pessoas com vidas pessoais, como pessoas envolvidas no mundo. E isso para mim é um tipo de declaração final que, suponho, coloca problemas se alguém procura levar isso a sério. Mas, na verdade, se queremos tornar a vida melhor para as crianças, então temos que levar isso a sério, porque elas não são uma categoria. Elas são indivíduos. De modo que, o livro trata deste assunto. Então, acho que é o meu caminho teórico. A milhas de distância de Jens [Qvortrup] realmente! O extremo, extremo oposto. Mas isso é bom, porque, na verdade, o que as crianças têm de lidar é com essa ampla categorização que as sociedades fazem para as crianças. E eu acho que isso é muito difícil”. 
A Profa. James se aposentou em setembro de 2014, sendo substituída por duas pesquisadoras, Dylan Yamada-Rice e Liz Wood, ambas da Educação. Mantida a Profa. Penny Curtis, co-diretora atual, o CSCY terá três diretoras.

\subsubsection{Dylan Yamada-Rice}

Diretora do Mestrado em Educação: Educação Infantil, Escola de Educação

A Profa. Yamada-Rice começa dizendo que é "relativamente nova na academia", porque terminou seu doutorado há um ano. Conta que "trabalho como professora aqui na Escola de Educação há dois anos, mas estou envolvida com o centro desde o início do meu mestrado, portanto há um longo tempo". Seu interesse está nas primeiras práticas comunicativas das crianças pequenas, como declara: "Estava realmente interessada na influência das imagens nas práticas de comunicação das crianças, assim como nas mudanças nas práticas comunicativas através da tecnologia digital, que as crianças possam acessar jogos e páginas da internet e similares, e o aumento, suponho, da publicidade em outdoores e coisas semelhantes, e como isso pode estar influenciando as primeiras práticas comunicativas das crianças". Ela "passou um ano no Japão trabalhando com um grupo de sete crianças entre as idades de três e seis anos de idade".

Afirma que "o centro foi muito importante para mim, porque reuniu muitas disciplinas de pessoas que consideram a infância por muitos ângulos diferentes, e [...] teve um efeito muito positivo para pensar sobre a infância a partir de diferentes ângulos. Além disso, acho que uma das coisas cruciais, para além da interdisciplinaridade, era ouvir pessoas em diferentes fases das suas carreiras, assim, portanto, ter pessoas que eram estudantes, e também ter pessoas como Allison James, que é professor e está prestes a 
se aposentar, e teve toda uma história, e, então, todas as pessoas entre os dois extremos. Senti que era realmente importante, assim como a interdisciplinaridade do centro também". Acrescenta: "O papel do centro, naquela época para mim, acho que era muito mais um lugar onde poderia me juntar a um grupo de leitura, e, porque era interdisciplinar, me apresentou a leituras que eu não teria normalmente acessado por mim. Outras pessoas no centro, como Allison James, poderiam talvez recomendar um artigo, lê-lo, e viriam e o discutiriam, como parte desse grupo".

Para ela, que está no grupo de interesse por métodos visuais, o grupo é muito favorável tanto sobre as ideias de leitura quanto às metodológicas, como, por exemplo, "eu poderia ir para o grupo e dizer: "Eu estou planejando dar câmeras às crianças", e o grupo devolveria: "O que você já pensou sobre isso?" Conta que "agora estamos trabalhando em um livro, olhando para os cruzamentos entre imagens e pesquisa, portanto pesquisa visual, e o tipo de pesquisa que tem lugar na indústria, então, produção teatral para crianças e produção de jogos. Estamos escrevendo um livro juntos. Estamos prestes a fazer uma exposição juntos no verão, para exibir o tipo de pesquisa visual que temos feito; obviamente, o traço comum são as crianças e jovens, mas para além dessas pessoas, serão feitos de maneiras diferentes. Sim, continuamos a ler e apoiar uns aos outros nesses caminhos".

A Profa. Yamada-Rice comenta o impacto do centro: "Acho que em termos do grupo dos métodos visuais houve impacto. [...] Por exemplo, sair e trabalhar com a indústria, eu acho que é algo que é realmente novo, e acho que muitas universidades ainda não estão fazendo isso, mas é importante. Como resultado do que estou agora trabalhando, num sabático de três meses na indústria, em uma empresa que produz jogos digitais para 
iPads e coisas para crianças, levando-os a pensar em trazer as crianças para o processo de design. Antes disso, a empresa de jogos digitais utilizaria seus conhecimentos técnicos para criar jogos e esperaria que as crianças gostassem deles, eu acho. Agora, sinto que estamos tentando uma abordagem para o outro lado, assim, o que acontece se consideramos a criança em primeiro lugar? O que os jogos pareceriam? Será que eles seriam realmente diferentes? Eu diria que isso é um impacto. Eu não sei o que vai acontecer, ainda, porque eu estou no meio [da pesquisa]. Além disso, há o livro em andamento. E ainda, obtendo sucesso com o resultado do grupo, elaboramos uma proposta conjunta para obter financiamento da universidade para desenvolver um Centro de Formação em Métodos Visuais, de modo que os estudantes de doutorado da faculdade de ciências sociais, se eles quiserem participar, poderão começar o treinamento em métodos visuais".

Ela é do campo da educação e, em relação à educação num centro interdisciplinar, afirma "utilizo meu tempo dando aulas de Educação, então sinto que levo essa experiência comigo quando vou para o CSCY, mas eu também estou plenamente consciente de que a infância existe no mundo, e a educação é uma parte disso. Por exemplo, há crianças que vivem num hospital, e os especialistas em jogos, que estão trabalhando com elas no hospital, sabem alguma coisa, têm um conhecimento muito especializado sobre brincadeiras infantis em um hospital, mas, do ponto de vista da educação, têm a experiência - assim, minha colega com quem estou trabalhando aqui, Profa. Liz Wood, tem várias décadas de conhecimento de pesquisa sobre o jogo infantil, e eu tenho focalizado a utilização das tecnologias digitais pelas crianças. Então, reunimos as formações teóricas com esse tipo de conhecimento muito especializado sobre crianças neste ambiente particular do hospital. Assim, acho que todos nós 
trazemos conhecimento especializado, mas há uma espécie de lugar para compartilhalo, que é o centro". Acrescenta: "Toda pesquisa terá que ser interdisciplinar para obter financiamento. Assim, embora estejamos baseados na Educação, não podemos ser puramente educadores. [...] é preciso ter uma ampla gama de perspectivas para desafiar algumas das formações teóricas, penso eu".

\subsubsection{Afua Twum-Danso Imoh}

Professora de Sociologia da Infância / Coeditora da Childhoods Today

A Profa. Imoh chegou ao centro em 2008, quando veio para a Universidade de Sheffield, para o Departamento de Estudos Sociológicos. Sua pesquisa "está focada na construção social da infância, especialmente no contexto do Oeste Africano, observando os valores culturais, como o respeito, a responsabilidade e as implicações para os direitos das crianças; observando as noções globais da infância e suas implicações para a universalidade contra relatividade, nos debates em torno dos direitos das crianças".

Ela conta que é "um tipo de pessoa interdisciplinar" porque fez a licenciatura em História e Sociologia, o Mestrado em Estudos de Desenvolvimento, e o doutorado em Estudos Africanos, "que reúnem a Antropologia, a Sociologia, os Direitos Humanos, o Direito e a Política Social. Afirma: “eu não sou realmente uma socióloga, não sou uma antropóloga, não sou uma historiadora, mas posso reunir essas áreas. E, para mim, quando faço isso e estou estudando a infância, me ajuda a desenvolver uma compreensão mais profunda de tudo o que eu estou observando. Se eu reunir História, Antropologia, Sociologia e, é claro, a Política Social, que é o que eu faço normalmente, isso me permite desenvolver 
uma imagem mais holística das vidas das crianças e das experiências das crianças. E eu acho que isso enriquece meu próprio entendimento e aprendizado".

A Profa. Imoh explica: "o centro é interdisciplinar; ele não pertence a qualquer departamento. Nós, como acadêmicos, pertencemos a nossos departamentos". Sua explicação provoca uma interessante questão sobre a localização do centro e como isso reflete nele. O CSCY não pertence a nenhum departamento, o que significa que "não temos, exceto Allison, eu acho, tempo para ser parte do centro. Assim, em sua carga de trabalho há tempo atribuído a ela para ser diretora do centro. Mas todo mundo que está envolvido com o centro não tem tempo destinado a ele em sua carga de trabalho. Assim, é no tempo livre", completa a Profa. Imoh. É dizer que cada pesquisador dá aulas e/ou propõe e consegue financiamento para sua própria pesquisa no departamento; o CSCY é como um ponto de encontro, para estudar, para trocar ideias e desenvolver estudos nos grupos de interesse, formulando propostas de pesquisa, discutindo artigos, escrevendo livros, por exemplo, em seu tempo livre.

Os membros do centro têm diferentes tipos de reuniões. Há reuniões do grupo estratégico, um pequeno grupo do qual faz parte, como coeditora da revista, e "as pessoas que têm papéis fundamentais no centro". Essas reuniões são realizadas a cada seis semanas para "discutir os negócios do centro, tentando ajudar a desenvolver o tipo de estratégia para ele". Há "reuniões mais gerais que outras pessoas participam, que não são frequentes. E há os seminários, seminários de pesquisa nos quais alguém vem e apresenta trabalho. Há o grupo de leitura, em que as pessoas vão e, eu acho, se encontram a cada mês ou a cada seis semanas. E, então, o centro tem grupos de pesquisa". A Profa. Imoh coordena o grupo de pesquisa chamado Infâncias Globais e 
este grupo se reúne a cada mês, "nós temos nos encontrado todos os meses por mais de um ano". Cada grupo de interesse tem líderes e se organizam particularmente.

Sobre o impacto acadêmico ou político do centro, a Profa. Imoh diz: "certamente está tendo um impacto em termos de ambientes acadêmicos [...] por causa do trabalho das pessoas no âmbito do centro, os livros que eles têm produzido, os periódicos em que têm publicado e pessoas como Allison [James], [...] há alguém na Educação, que recentemente ganhou um prêmio de impacto [...] Cathy Nutbrown. Ela acaba de ganhar um prêmio de impacto, o ESRC ${ }^{94}$, e ela faz parte do centro. Assim, tem havido impacto certamente nos círculos acadêmicos". Continua dizendo que "impacto sobre a política, [...] há uma comissão de parceria do centro, que é composta por pessoas de várias agências, como o Serviço de Proteção à Criança, o Conselho da Cidade de Sheffield, o Conselho de Rotherham, e algumas organizações que trabalham com os profissionais e com as crianças [...] eles se alimentam do centro. Mas é tudo muito local. Então, eu acho que talvez em um nível local, dentro de Sheffield, South Yorkshire, o centro poderia ter um impacto na política também. Eu não sei como isso foi medido ou se já foi medido, mas certamente entre as pessoas acadêmicas dentro do centro há impacto".

Questionada sobre o papel da Educação em um centro interdisciplinar, a Profa. Imoh responde que "desempenha um papel muito fundamental. Muitas pessoas que atuam no centro são da Educação e temos pessoas da Geografia e da Sociologia e do Paisagismo, mas muita gente de Educação, talvez porque [...] ]estejam fazendo pesquisa sobre crianças de uma forma ou de outra. Eles têm muitos estudantes de doutorado, bem como os que chegam a cada ano, de diferentes países, querendo fazer isso

\footnotetext{
${ }^{94}$ Prêmio de Impacto do Conselho de Pesquisa Econômica e Social 2013.
} 
[pesquisa] também". Acrescenta: "mas, então, eu não sei em que medida eles olham para o aprendizado fora do ambiente escolar e talvez eles façam... para ser honesta, não conheço os vários projetos de investigação em curso na Educação. Mas para mim, estou interessada em como as crianças aprendem fora, não necessariamente na escola. E uma das coisas que me interessam agora é saber se uma educação baseada na escola é útil para as crianças de, talvez remotas, áreas rurais da África. Em que medida uma educação baseada na escola lhes fornece as habilidades que precisam? " Comenta que as pessoas da educação são muito ativas no centro, que precisa de mais "sociólogos da infância, mais de historiadores da infância, de geógrafos infância, e estes precisam ser muito ativos nos estudos da infância". Segundo ela, há pessoas da Geografia, mas "não são tão visíveis no centro. Uma vez que Allison se aposente, sou a única neste departamento que analisa a infância a partir de uma perspectiva sociológica. [...] Assim, há pessoas da Odontologia, mas também não tão ativas como talvez costumavam ser. Do Paisagismo, uma pessoa, não muito ativa quanto poderia ser, mas as pessoas de Educação são muito, muito ativas". Neste sentido," o centro pode se tornar um Centro de Educação porque [esta disciplina] está agora jogando nos papéis-chave".

Até agora, foram apresentados os perfis dos centros e de seus estudiosos, elaborado a partir de entrevistas. A seguir, algumas reflexões sobre seus aspectos contextuais. 


\section{Capítulo 4}

\section{Considerações sobre os centros de pesquisa}

\subsection{Aspectos contextuais dos centros de pesquisa}

Na perspectiva de contexto como conteúdo sociológico, Zusman, Knox e Gardner (2009) indicam que "o contexto social limita alternativas, restringe decisões e cria resultados" (Id.). Desta forma, "contexto social refere-se aos padrões de relações humanas e interações que caracterizam a vida social" (Ibid., p.5). No caso dos centros de investigação, o surgimento de cada um, o lugar em que o centro ocupa na universidade, as relações entre os pesquisadores e a pesquisa, a oportunidade para o intercâmbio com pesquisadores de outros centros/países, a possibilidade de investigação conjunta e acesso ao financiamento são alguns dos aspectos contextuais que podem ser examinados. No capítulo anterior, os trechos escolhidos tentaram mostrar o caráter próprio de cada centro, como refletido nas palavras de seus pesquisadores. A seguir, sínteses dos contextos cada centro, a partir das falas de seus pesquisadores.

\subsubsection{CIEC}

O IEC ocupava o lugar de uma escola universitária independente, cujo objeto eram os Estudos da Criança, que foi inserido ao Instituto de Educação por ocasião de uma reforma empreendida pela universidade. Como entender o contexto da CIEC? Está em uma escola da Educação e esta característica parece determinante. Mesmo que a Profa. Carvalho enfatize o foco dos estudos nas crianças em sua fala, a educação parece ser privilegiada pois, exceto para a linha de pesquisa coordenada pelo Prof. Sarmento 
(Contextos e práticas sociais das crianças - grifo meu), as outras vertentes, que trazem crianças ou criança em seus títulos, são fundamentalmente localizadas num "para a" criança, seja como educação (Saúde da criança, Meio Ambiente e Educação Física; Produções culturais [para crianças]) ou voltadas para a formação de professores (Profissionais da infância; Recursos pedagógicos para crianças). Num contexto com essas características, num primeiro momento, torna-se possível reconhecer a inter ou a multidisciplinaridade como uma possibilidade antes definida pelas disciplinas curriculares disponíveis para estabelecer parcerias e relações. Ou, ao contrário, reconhece-se a interdisciplinaridade como facilitadora da aprendizagem, como elemento que permite ao estudante compreender conteúdos escolares, numa perspectiva curricular.

Além disso, o centro como está organizado não permite um movimento para trazer outros pesquisadores de diferentes disciplinas para agir/trabalhar/pesquisar/discutir com os pesquisadores do CIEC. Mesmo em relação à equipe, o centro, como diz a Profa. Carvalho, oferece poucas possibilidades de diálogo entre as diferentes áreas. Em suas palavras, isso pode acontecer quando há preparação de projetos para financiamento externo. Ela diz que a equipe tem muitas aulas para dar e estudantes para orientar e não tem tempo para pesquisar conjuntamente. O que parece pautar-se pelo interdisciplinar são os projetos ou as pessoas de diferentes campos do conhecimento que lá desenvolvem sua pesquisa, como a estudante de doutorado entrevistada.

Este parece ser o contexto do desenvolvimento e produção de pesquisas do centro. Seu lugar e seu espaço estão na educação institucional, escolar, e métodos, currículo e formação de professores parecem ser, a partir das linhas formuladas, as principais 
questões que determinam o contexto. Os Estudos da Infância, notadamente a Sociologia, constituem uma corrente minoritária, apenas uma linha de pesquisa que traz as crianças e a infância como foco. Cabe destacar, contudo, que o contato com as literaturas britânica e francesa do mesmo campo qualifica e amplifica a pesquisa e a produção de teoria. Soa como um paradoxo, mas parece ser o resultado das intervenções políticas/burocráticas, mencionadas pelo Prof. Sarmento, e, ao mesmo tempo, uma consequência de seu esforço para manter os Estudos sobre Infância em destaque no centro.

\subsubsection{Interdisciplinary Center Childhoods.Societies}

Parece interessante recuperar o surgimento do centro, nas palavras do Prof. Sünker: um acaso. Ele, que estudava educação, pedagogia social, política social acabou por apresentar trabalho sobre a infância e envolver-se com os momentos iniciais de definição do campo da Sociologia da Infância, como relata. Este centro está localizado em um lugar de Educação, não de Pedagogia Escolar, como o Prof. Sünker reforça durante toda a entrevista, mas de Pedagogia Social. Ele explica que a Pedagogia Escolar tem crianças como objeto de estratégias educativas, enquanto que a social trabalha com questões mais amplas.

O centro não tem uma sede própria, mas é um espaço que reúne estudiosos de diferentes áreas, para o planejamento de pesquisas sobre as questões da infância. Parece haver um movimento dinâmico em direção a aspectos de pesquisa mais 
próximos e a pesquisadores por meio de seminários e conferências internacionais ${ }^{95}$, como se evidencia nas falas da Profa. Braches-Chyrek e da Profa. Potsi. Promove debates interdisciplinares congregando a Educação, a Pedagogia Social, a Sociologia, os Esportes, a Música, a Linguística e a Literatura, bem como procura outras áreas para agregar a esses estudos, de acordo com o projeto que esteja em pauta. Este movimento é reforçado quando se trata de submeter projetos de investigação que envolvem outras universidades da Europa para conseguir financiamento da União Europeia. O interesse, por exemplo, do governo alemão num financiamento maior faz com que contribua, como destaca a Profa. Potsi, promovendo encontros de pesquisadores e fornecendo financiamento básico.

\subsubsection{NOSEB}

Este centro tem o mesmo status de um departamento na universidade. Como mencionado anteriormente, o centro convida pesquisadores de renome internacional da área da Infância para trabalhar com pesquisadores locais e enfatiza a pesquisa interdisciplinar, incluindo a Geografia, a Antropologia Social, a Sociologia, a História e a Pedagogia. Há uma forte referência à teoria, com o paradigma de estudos da infância, e às ideias e pesquisas de Jens Qvortrup, embora, conforme observação da Profa. Tingstad, os pesquisadores ainda discutam agência e estrutura. Ela enfatiza que o centro nunca foi parte de um instituto, embora ocupe o mesmo espaço físico que o Instituto de Educação. Para ela, este Instituto não é o lugar de onde vem os colaboradores mais

\footnotetext{
95 Entre 10 e 11 de julho de 2014, o centro promoveu o Simpósio Internacional "Crianças - Infância - Estado -Educação", organizado por Heinz Sünker e Jo Moran-Ellis, que trouxe "pesquisadores internacionais para examinar criticamente as diferentes relações entre o Estado, a criança e a educação em sentido amplo".
} 
interessantes: estes são da Geografia, da Antropologia e da Sociologia, que são mais semelhantes ao observar a sociedade.

De acordo com a Profa. Kjørholt, a equipe teve de se adaptar ao reitor e à estrutura da universidade, que lhe exigiu, como diretora, e ao centro, o desenvolvimento de programas de mestrado e doutorado e não somente a realização de pesquisa. Assim, o NOSEB produz pesquisa internacional, como os projetos liderados pela Profa. Kjørholt e Prof. Qvortrup já referidos, as pesquisas de mestrado e doutorado, e aquelas desenvolvidas por pesquisadores que trabalham com um tema semelhante, como, por exemplo, o consumo infantil. Trata-se de um centro dinâmico onde pesquisadores locais e internacionais frequentemente organizam workshops, seminários internacionais e publicações, além de conseguirem financiamento, com base em sua produção.

\subsubsection{CSCY}

Como mencionado anteriormente, apesar de não pertencer a qualquer departamento, o CSCY ganhou reconhecimento oficial na Universidade como um de seus centros de investigação. É um centro interdisciplinar que reúne cerca de dez departamentos, incluindo Sociologia, Educação, Geografia e Paisagismo. Um grupo estratégico o dirige, garantindo a realização de um programa de atividades, produz seu jornal, trabalha com a gestão das finanças, entre outras atribuições. Além disso, há grupos de pesquisa formados em torno dos interesses das pessoas, todos interdisciplinares. Parece interessante destacar que alguns grupos parecem ter as crianças como foco, Crianças e relações intergeracionais; Espaços e lugares das crianças; Infâncias globais, enquanto que outros parecem ser para as crianças, como Grupo de pesquisa visual; Saúde do 
corpo e bem-estar; Crianças e famílias vulneráveis: Promovendo a resiliência; Deficiência@UOS. Os pesquisadores desenvolvem estudos, formulam propostas de pesquisa, discutem artigos, e escrevem livros, entre outras atividades do grupo. É possível participar de até três grupos.

De acordo com a Profa. James, a cada ano, o CSCY tem um evento de boas-vindas para apresentar os novos estudantes para os antigos. Trata-se de uma oficina que ocorre no primeiro semestre, muitas vezes sobre métodos de investigação ou sobre ética, por exemplo. Os estudantes de pesquisa, tanto os do centro, quanto os internacionais, apresentam trabalhos e têm a oportunidade de reunir-se. Em janeiro, outro evento é realizado, no qual um pesquisador dá uma palestra e os estudantes fazem comunicações. A cada dois anos, há um curso de verão de pós-graduação, que se alterna com uma conferência internacional, e atrai estudantes de todo o mundo. Os recursos para o $\mathrm{CSCY}$ vem desses eventos.

As sínteses apresentadas aqui reforçam as diferenças e especificidades da cada um dos centros. A seguir, a discussão de alguns elementos a partir das questões da pesquisa.

\subsection{Interdisciplinaridade: princípio e/ou abordagem teórico-metodológica}

Poder-se-ia considerar a interdisciplinaridade tanto como princípio quanto como abordagem teórico-metodológica em cada um dos centros? Há significativas diferenças em relação à utilização do termo, como se verá a seguir.

Para o centro norueguês, a interdisciplinaridade é um dos elementos do paradigma dos estudos da infância, como destaca a Profa. Kjørholt, "há um caráter interdisciplinar nos 
estudos sociais das crianças e da infância, para compreender a vida das crianças, o desenvolvimento das crianças, sua educação, tanto conectado a contextos culturais diferentes quanto às diferenças de tempo e lugar". Dessa forma, é um princípio e uma abordagem teórico-metodológica, ou seja, não é uma questão a ser discutida, como agência e estrutura, por exemplo. Além disso, foi uma estratégia para abrir o centro para a internacionalização, quando ela convidou pesquisadores de fora para um trabalho conjunto no NOSEB.

Conforme o Prof. Sünker, "temos este debate alemão, interdisciplinar, transdisciplinar e multidisciplinar e, francamente falando, ninguém sabe claramente o que isso significa". O que não parece constituir um problema, mas um aspecto a ser praticado. Em outras palavras, trata-se de um ponto de partida para discutir algum tema específico, como explica o professor: "o tema era desvantagem na primeira infância e a abordagem interdisciplinar significava reunir a Pedagogia Social, a Pedagogia Escolar, a Teoria da Educação, a Geografia Social, a Linguística", ou seja, a interdisciplinaridade é um princípio metodológico. De acordo com ele, “a abordagem interdisciplinar ainda tenta mediar as diferentes metodologias, os diferentes métodos, as diferentes abordagens, as diferentes perspectivas, porque, eu diria, especialmente em relação a todos os fatos sociais, a todas as aparências sociais, você pode ter pontos de vista diferentes sobre o assunto de sua pesquisa".

No centro português, o Prof. Sarmento contesta a ideia de estudos interdisciplinares da infância e acredita que multidisciplinar aplica-se melhor ao conjunto de disciplinas que se reúnem para o estudo da infância, isto é, "a interdisciplinaridade é algo que se aspira, mas talvez seja mais preciso definir o nosso centro, o $\mathrm{ClEC}$, como um centro 
multidisciplinar e não um centro interdisciplinar. Ou seja, um centro em que várias disciplinas estão presentes e sua interseção ainda é um projeto em andamento, algo que está sendo estruturado com algumas dificuldades". É importante ressaltar que a vertente que ele coordena trabalha interdisciplinarmente: as áreas articuladas são Sociologia da Infância, Artes e Ciências do Lazer, como ele declara na entrevista.

Em relação ao centro britânico, a Profa. Yamada-Rice pondera que "o centro [...] reuniu várias disciplinas, pessoas que consideram a infância de diferentes ângulos, e acho que isso teve um efeito muito positivo sobre pensar sobre a infância a partir de diferentes ângulos". A ideia de interdisciplinaridade, contudo, pode ser compreendida em outra perspectiva, como se verifica na fala da Profa. Imoh: "o centro é um centro interdisciplinar, que não pertence a qualquer departamento. Nós ... nós como acadêmicos pertencemos a nossos departamentos".

A fala Profa. Imoh remete ao lugar que o centro ocupa na universidade e como isso repercute em seu funcionamento. Ela explica que "não temos, para além de Allison, eu acho, tempo para ser parte do centro. Assim, na carga de trabalho dela há tempo atribuído para ser diretora do centro. Mas todas as pessoas que estão envolvidas com o centro não têm carga horária para ele. Portanto, é no seu tempo livre [que participam]".

Ao contrário do NOSEB, que é como um departamento, de acordo com a Prof. Kjørholt: "quando estávamos fora da universidade, só fazíamos pesquisa. Quando fomos incluídos, tivemos que nos adaptar ao reitor e à estrutura da universidade" embora permaneçam como um centro autônomo, como informa a Profa. Tingstad. 
Para o Prof. Sarmento, inserido no Instituto de Educação, "considerou-se que os Estudos da Criança eram basicamente uma área de pesquisa e ensino [...] O atual Instituto de Educação não tem departamento de Estudos da Criança, mas possui formação avançada em Estudos da Criança, mestrado e doutorado, e tem um centro de pesquisa em Estudos da Criança".

Quando o centro Childhoods.Societies foi proposto, "a universidade esclareceu que queria poucos centros de pesquisa interdisciplinares", explica o Prof. Sünker. E acrescenta: "o centro foi criado por uma decisão, em primeiro lugar, um ato do reitor, e, em segundo lugar, o acordo ou o voto do Senado ${ }^{96}$ [que] votou sim [...]".

As diferentes referências à interdisciplinaridade na origem e/ou no funcionamento dos centros provocam uma reflexão sobre o lugar que estes ocupam na estrutura da universidade e essa discussão remete ao texto de Jacobs e Frickel (2009), anteriormente mencionado.

Jacobs e Frickel (2009), fazendo uma avaliação crítica sobre a interdisciplinaridade, apontam o aumento dos centros de pesquisa nas universidades norte-americanas. Segundo eles, havia "quase 10.000 centros de pesquisa localizados em faculdades e universidades nos Estados Unidos em 2007" (p.53) e havia "frequentemente mais centros de investigação do que departamentos disciplinares" (id). Este é uma informação interessante porque existe uma contradição entre estes dois organismos: efetivamente os departamentos são frequentemente disciplinares, em oposição à natureza dos centros. Neste sentido, destacam que

\footnotetext{
${ }^{96}$ Equivalente a um Conselho Universitário.
} 
embora os defensores da interdisciplinaridade critiquem a natureza ostensivamente conservadora das disciplinas acadêmicas, é claro que a universidade baseada em departamentos acadêmicos coexiste com um número crescente e com a matriz diversificada dos centros de pesquisa que, no mínimo, representam um contexto organizacional que reúne estudiosos de diversas origens com interesses comuns. Será possível que tais centros facilitem a comunicação entre as fronteiras disciplinares? (p.54)

A questão formulada remete a uma pesquisa realizada por Diana Rhoten, publicada em 2005. Segundo a pesquisadora, a convivência das duas estruturas vai indicar que "centros com maior número de professores filiados promovem mais compartilhamento de informação" e que as relações entre os seus membros com "outros membros do centro têm influenciado positivamente suas próprias agendas de investigação" (RHOTEN, 2005, p.9). Ela argumenta que, num primeiro momento, a diversidade vai provocar mais a criatividade do que a produtividade, e critica as iniciativas das universidades que, segundo ela, devem "redesenhar e não apenas mudar o nome das estruturas e, assim, apoiar ativamente a pesquisa interdisciplinar" (Id.). Destaca ainda "que os centros tendem a ser organizados em torno de temas guarda-chuva em vez de unificar definições do problema e, consequentemente, ficam aquém de alcançar os níveis de transformação das sínteses interdisciplinares (p.10)". Ainda que falando do ponto de vista organizacional, ela reforça que "as universidades, portanto, terão de reconsiderar as prioridades e práticas de educação e formação de pós-graduação, a fim de preparar os indivíduos para esses centros [interdisciplinares]" (p.11).

Comentando o texto de Rhoten (2005), Jacobs e Frickel (2009) concluem

que um padrão mais modesto da conscientização e cooperação interdisciplinar coloca seus dados [de Rhoten] sob uma luz mais positiva. Além disso, se a participação voluntária em centros de pesquisa interdisciplinares não produz verdadeira interdisciplinaridade, vale a pena considerar que tipos de configurações organizacionais poderiam ser mais propícios à investigação interdisciplinar e bolsas de estudos. (p.54) 
Interessante notar que ambos os estudos foram realizados nos Estados Unidos e focalizam a qualidade da interdisciplinaridade em centros de pesquisa interdisciplinares. Este tipo de estudo permite uma visão mais ampla dos centros pesquisados, ao apresentar elementos sobre a convivência entre o centro e o departamento onde está localizado, como o CIEC, por exemplo, ou quando é semelhante a qualquer outro departamento, como o NOSEB. A complexidade da relação entre pesquisa e contexto, presente nas vozes dos entrevistados, passa também por questões de ordem organizacional, embora não caiba aqui um aprofundamento da questão, que parece demandar uma pesquisa por si só.

Uma segunda reflexão, que emerge dos dados, mas era uma questão inicial, apresentada na justificativa do projeto, refere-se ao papel da educação nos estudos da infância. Em relação ao centro português, como diz o Prof. Sarmento, "os estudos da criança foram inseridos no Instituto de Educação [...] o Centro de Estudos da Criança é, portanto, uma estrutura híbrida, não nasceu de um projeto científico perfeitamente claro, mas resulta de um processo histórico institucional que levou à situação atual". Parece importante destacar que a educação é poderosa mesmo quando o centro funciona com base em outras disciplinas, visto que sedia, como neste caso, o Instituto em que contém o centro.

Prof. Sünker afirma que o centro tem "uma longa lista de membros, mas o desafio é reunir educadores, pedagogos sociais, sociólogos, desportistas, músicos, linguistas, literatos [...] O desafio será continuar com o trabalho e trazer as pessoas para uma verdadeira cooperação". Interessante destacar que ele refere a educação em dois lugares distintos: a pedagogia social e a escolar. É à última que se refere quando afirma 
que a educação recebe mais financiamento do que outras áreas, ou seja, "eles obtêm recursos para pesquisa, porque não prejudicam ninguém".

Apesar de o NOSEB encontrar seus colaboradores mais interessantes na Geografia, Antropologia e Sociologia, como disse a diretora do centro, este fica no prédio do Instituto de Educação. Neste sentido, teria essa alocação alguma relação com a frequente conexão entre crianças e educação? Cabe também recuperar que tanto a Profa. Kjørholt quanto a Profa. Tingstad vem da educação infantil.

Em relação ao CSCY, uma de suas diretoras, do departamento de Ciências Sociais, foi substituída por duas pesquisadoras da escola de educação. Se é fato que a Profa. James diz "não, não é educação; Liz e Dylan realmente não fazem educação, como na educação", revelando que também ela enxerga a educação em mais de uma vertente, a Profa. Imoh, por sua vez, revela sua preocupação, comentando que as pessoas da educação são muito ativas no centro, ou seja, "o centro pode se tornar um centro de educação porque elas estão agora em posições chave".

Cabe considerar que a educação, como campo, como perspectiva de emancipação, como direito ao acesso àquilo que já foi e está sendo produzido pela humanidade, tem um sentido mais amplo do que a educação restrita ao espaço escolar. Entretanto a educação escolar é um direito de todos. As diversas falas nas entrevistas apontam na direção da possibilidade de composição com a educação, campo integrante, direta ou indiretamente, dos estudos da infância. Em texto recente, argumento que

tem sido interessante perceber que, embora seja reconhecida a complexidade da infância, a possibilidade do estabelecimento de ampliação das relações entre disciplinas ainda parece estar em estado embrionário, seja porque cada disciplina reluta em despir-se do poder investido em si, seja pela dificuldade em reconhecer-se numa relação de 
interdependência com outras disciplinas, como quer Alanen (2012). (NASCIMENTO, 2015, p.88-89)

Neste caso, para a educação, abrir mão do poder $^{97}$ sobre a infância pode significar a possibilidade de um trabalho compartilhado, se não inter, multidisciplinar. Evidentemente essa questão não se encerra aqui, oferecendo oportunidade para nova pesquisa, mais específica.

\subsection{0 que pode ser particular no estudo de infância?}

Outra questão interessante, que surge a partir dos dados, é o que pode ser particular no estudo de infância? Ou, nas palavras da Profa. Moran-Ellis, "qual é a diferença entre estudar a infância ou a pobreza? Um estudo sociológico de uma ou de outra questão é em primeiro lugar um estudo sociológico ${ }^{98 \prime \prime}$.

Pensar um estudo sociológico, do ponto de vista das metodologias de pesquisa, remete a um artigo de Punch (2002) que discute porque a pesquisa com as crianças seria potencialmente diferente das pesquisas com adultos. Ela explora questões metodológicas, em busca de alguma especificidade ou, pelo menos, de possibilidades de investigação muitas vezes consideradas "tão problemáticas quanto benéficas" para uso com crianças. E do ponto de vista teórico? Como se poderia responder à provocação proposta pela Profa. Moran-Ellis?

Considerando os diferentes contextos em que os centros de pesquisa desenvolvem seus programas de investigação, existem algumas coisas em comum entre eles. Pesquisa

\footnotetext{
${ }^{97}$ O estudo de Narodowski (1999) permanece atual.

${ }^{98}$ Questão formulada em uma de nossas reuniões, quando as entrevistas já tinham sido realizadas,
} 
baseada em agência é uma delas. Quando Grecia, estudante de doutorado do CIEC, fala sobre sua pesquisa, é clara: todas as crianças do grupo são agentes, que trabalham em conjunto para produzir um programa de rádio, na linha da educomunicação. A Profa. Imoh buscou pela agência nas crianças de Agra. A Profa. Braches-Chyrek enfatiza a escuta da voz das crianças, isto é, reconhecendo sua agência.

A Profa. Kjørholt comenta que

estou inspirada na antropologia porque a perspectiva antropológica [...] quando você faz a pesquisa etnográfica e tenta entender e compreender as perspectivas de diferentes pessoas em diferentes países, contextos [...] valores que eles têm, o que eles vêem como uma boa vida, sim, diferentes práticas cotidianas na comunidade, na família, entre as crianças e assim por diante. $O$ caráter interdisciplinar dos estudos sociais das crianças e da infância [leva a] compreender a vida das crianças, o desenvolvimento das crianças, a educação das crianças, como ligada a esses contextos culturais diferentes e as diferenças de tempo e lugar, 0 que é atraente para mim como pesquisadora. (Entrevista 3.2.3.2)

Ao acrescentar que também se inspira no filósofo americano Charles Taylor, diz que ele refere "a autonomia e a autonomia individual, a liberdade de escolher e os valores da independência na autonomia, valores normativos. [...] Jens [Qvortrup] está falando sobre estrutura. Ele enfatiza a estrutura social e econômica a fim de entender as pessoas. Eu estou inspirada no conceito de discurso, que é pós-estruturalista". Fala sobre o discurso "de maneira a substituir o conceito de cultura", estendendo-se sobre o que pode ser entendido como o singular substituindo o universal.

A posição da Profa. James presente em sua entrevista e em seu livro de 2013, pode ser indicada por

Em suma, gostaria de argumentar que, apesar das aparências, há vida epistemológica deixada nas antigas teorias que vai sim beneficiar a nossa compreensão das maneiras pelas quais as crianças aprendem sobre o mundo social. Baseando-se no pensamento teórico recente dentro da Sociologia, da Antropologia e da Psicologia cognitiva, e incorporando uma gama de material empírico gerado com as próprias 
crianças em diferentes configurações, este livro apresenta, em seguida, um manifesto para as maneiras pelas quais o conceito de socialização pode ser reconfigurado a partir de uma perspectiva dos estudos da infância. (2013, p.5-6)

Ela volta ao conceito de socialização, que entende como fundamental para trabalhar com as crianças e a infância, em uma nova configuração.

No meu ponto de vista, esta posição está perto de uma espécie de Sociologia que pode ser chamada de Sociologia das disposições e tem Bernard Lahire como um de seus principais autores. Segundo o sociólogo, "aos poucos, mesmo sem reconhecê-lo ou estar em condições de avaliar as suas consequências, a Sociologia tem vindo a se interessar em socializar indivíduos como tais, bem como em grupos sociais, estruturas, contextos e interação" (2011, p.195). E completa:

O trabalho sociológico contemporâneo muitas vezes usa expressões tais "disposições", estruturas "cognitivas" ou "mentais", "procedimentos interpretativos", "categorias de percepção" ou "representação", "etnometodologia", "estoque de conhecimento", "reserva de experiências anteriores", "relações com o mundo" ou "visões de mundo". Mas os autores em questão estão mais frequentemente satisfeitos em pressupor a existência destas "disposições" ou "estruturas" dentro do ator, ao invés de realmente tomar como um programa de pesquisa o estudo de sua construção e seu possível (mas não necessariamente sistemático) reinvestimento em novos contextos sociais. Não é possível, sem impunidade, no entanto, para empregar um vocabulário próximo ao da Psicologia, sem em algum momento acionar o desejo, um [estudo] genuinamente sociológico, de submeter a um questionamento crítico e uma avaliação empírica - breve, para examinálo mais de perto. Se tivermos em conta que a Sociologia, e não apenas Psicologia, está preocupada em analisar o funcionamento de comportamentos dessas "pequenas máquinas" produzindo comportamentos, ações, avaliações, escolhas, etc., que são atores, é importante equipar-se com ferramentas conceituais adequadas para fazer progressos neste domínio. (p.197)

Lahire não está nas referências da Profa. James, mas eles caminham muito próximos quando ele fala sobre uma Sociologia psicológica, ou seja: "estudar o indivíduo que cruza cenas diferentes, contextos, campos de força e de luta, etc. é estudar a realidade social em sua forma individualizada, incorporada, interiorizada" (2011, p.196). Cabe lembrar 
que ela comenta, divertida, que está há milhas de distância de Jens Qvortrup, na entrevista.

De acordo com ele,

\begin{abstract}
A infância como forma estrutural não é, como a criança, definida em termos de características ou disposições individuais, mas em termos de parâmetros contextuais. Estamos tratando de macro parâmetros tais como modo de produção, nível industrial ou tecnológico, sistema sociopolítico, formação cultural, globalização, militarização, irregularidade neoliberal, mercado e outros parâmetros dessa amplitude. Eles influenciam, tipicamente, adultos e crianças, embora não necessariamente da mesma forma e na mesma extensão. (QVORTRUP, 2007, p.58)
\end{abstract}

Este parece ser um saudável debate, mas não se caracteriza como único. Ainda do ponto de vista teórico, como outra alternativa, Alderson trabalha com o realismo crítico dialético (DCR). Ela diz, em seu livro de 2013, que "este livro está preocupado com a ausência das crianças e da infância em praticamente qualquer relatório, livro ou filme sobre política, economia, comércio, conflito armado, habitação, transportes, alterações climáticas ou qualquer tópico importante de interesse público" $(2013$, p.3) e que "a ausência é um conceito central no realismo crítico dialético" (id.).

Explica que "o DCR não é uma versão da Sociologia", mas uma "filosofia das ciências naturais e sociais" (p.4). Alista alguns problemas nos estudos da infância: não há financiamento suficiente; a pesquisa é repetitiva; há pouco tempo para desenvolver a investigação; a reputação e as alianças estão comprometidas porque "os estudos da infância não se tornaram parte da Sociologia convencional" (p.17); há desacordos não resolvidos entre os cientistas sociais; há uma separação da infância das sociedades adultas. Considera ainda que 
os estudos da infância tendem a tornar-se um refúgio da ciência social e da sociedade convencionais, onde as crianças são bem-vindas, mas, no entanto, contidas e excluídas da "política e das questões de peso". O DCR oferece formas de reforçar a validade da pesquisa social crítica com crianças e jovens. (p.18)

Enquanto Alderson apresenta perguntas, recupera e defende essa tendência, Sünker indica problemas semelhantes, mas aponta outro caminho, o da Escola de Frankfurt. Ele diz que "às vezes aprendo com a Sociologia que o que pode ser feito é realizado como uma análise social, como Leena [Alanen] e Doris [Buehler-Niederberger] fazem, lidar com a relação entre as gerações. Felizmente na tradição alemã, Walter Benjamin, cem anos atrás, já discutia esta questão em suas contribuições para a infância e juventude". Comenta sobre a mudança do entendimento de "socialização" de outra maneira:

inventei em um dos artigos, que escrevi junto com Doris [BuehlerNiederberger], o termo capital geracional. Capital de gerações. E esse é um dos pontos relevantes, lidamos com a transição das socializações, dos antigos estudos da infância para os novos estudos de infância, e o que isso significa para a superação das teorias de socialização? E lidamos com a questão, especialmente Doris, sobre qual era a vantagem da abordagem da socialização? Ela argumenta, e penso que é bastante interessante, que na antiga abordagem o termo socialização lidava com a desigualdade social, as desigualdades sociais na infância, e os novos estudos da infância muitas vezes se esquecem dessas desigualdades sociais. (Entrevista 3.2.2.1)

Parece-me muito interessante observar quão diferentes são essas abordagens sociológicas da infância. A mesma questão, ou uma muito semelhante, tem referências tão variadas como os contextos em que são formuladas. Neste sentido, a compreensão de infância é mais do que a definição de uma Sociologia da Infância. É usar a Sociologia para entender e analisar a infância. Talvez se possa dizer Sociologias da Infância.

Parece, entretanto, importante não esquecer que todas estas possibilidades têm crianças como unidade de estudo, como Qvortrup enfatiza, colocando a infância em um contexto, como ele diz: 
Eu concordo, naturalmente, com a necessidade de ter teoria e perspectivas teóricas, isto é, naturalmente, bastante decisivo porque senão você pode sair, fazer suas observações, você pode escrever sobre ... mas você precisa ser capaz de colocar isso em um contexto a fim de chegar a compreender o papel da infância e das crianças na sociedade. E para isso não é suficiente apenas recolher dados sem conectá-los a ideias e pensamentos e assim por diante. (Entrevista 3.2.3.3)

Eu poderia sugerir que, mais do que divergência ou diferença, as várias formulações refletem um contexto mais amplo e o contexto particular em que são - cada uma formuladas, o que seria objeto de nova investigação, com esse recorte. 


\section{Considerações finais}

A elaboração de uma tese de Livre-Docência é um interessante exercício. Do ponto de vista da autoria, permite expor diferentes momentos do trabalho intelectual, revelando mudanças no entendimento de conceitos, aprofundamento naquilo que incomoda, que instiga, o distanciamento ou a aproximação a autores. Não é tarefa fácil. Talvez seja uma questão particular, mas prezo pela coerência e, de certo modo, foi o que persegui neste trabalho. De certo modo porque o campo da Sociologia da Infância me provoca de formas diferentes, como, creio, os capítulos fazem ver. Vou buscar recuperar alguns pontos.

Nos últimos anos, pode-se reconhecer um aumento na produção de pesquisa sobre a infância pela ótica das ciências sociais, que tem investigado as crianças, explorando metodologias de pesquisa com elas e avançando na compreensão da infância e das crianças no mundo contemporâneo. A investigação coordenada por mim entre 2010 e 2012, realizada com grupos de pesquisa brasileiros sobre a infância, cujo objetivo era mapear aqueles que trabalham com a sociologia da infância, identificando os conceitos da área mais utilizados por cada um deles, e sua produção, para delinear a extensão da pesquisa nesse campo, constatou a predominância do campo da Educação, mais especificamente, da educação infantil como interlocutor da Sociologia. Nesse sentido, as proposições teórico-metodológicas do campo da Sociologia da Infância têm contribuído para a realização de estudos sobre o cotidiano das crianças pequenas, para a utilização de abordagem etnográfica em pesquisas sobre agência, tendo como arena, principalmente, instituições de educação infantil. 
Ainda que essa constatação seja positiva e fortaleça a pesquisa sobre a pequena infância, oferecendo elementos para seu melhor conhecimento, parece necessário ampliar, por um lado, a faixa etária contida na pesquisa, de pequena infância para infância ${ }^{99}$, e, por outro, as arenas e os contextos outros, nos quais as crianças estabelecem relações sociais diversas.

Hutchby \& Moran-Ellis (1998), discutindo a competência social das crianças, defendem que "para pensar crianças como agentes sociais competentes, contudo, é necessário conectar a competência social integral às atividades do mundo real com os quadros estruturais e interacionais do cotidiano nas sociedades modernas" (p.14). Em outras palavras, competência social se realiza em arenas de ação, em contextos nos quais "as crianças manipulam competentemente recursos materiais e culturais de modo a se engajarem em comportamentos contextualmente apropriados" (Id.). Para estes pesquisadores, as arenas de ação são a família, o grupo de pares - arena de fala e interação - e a arena de conhecimento institucional. Em consonância, Mayall (2002) vê a arena social como determinante para a experiência infantil. Tisdall e Punch (2012) defendem uma maior ênfase sobre os meandros, complexidades, tensões, ambiguidades e ambivalências das vidas das crianças e dos jovens nos contextos do mundo majoritário e minoritário (p.259).

Alderson (2013) constata que se evidencia a "ausência de crianças e infância a partir de praticamente qualquer relatório, livro ou filme sobre política, economia, comércio, conflito armado, habitação, transportes, alterações climáticas ou qualquer tópico

\footnotetext{
${ }^{99}$ Nesse caso, tomando o ECA como parâmetro e considerando infância até 12 anos.
} 
importante de interesse público" (p.3). Segundo ela, "os estudos da infância tendem a tornar-se um refúgio das ciências sociais e da sociedade convencionais, onde as crianças são bem-vindas, mas, no entanto, contidas e excluídas da política e de questões importantes" (Id.). Esta constatação conclama à investigação das relações infância e sociedade, que poderão gerar conhecimento, por exemplo, sobre infância, relações geracionais, de gênero, étnicas e de classe social; direitos das crianças, participação e construção da cidadania; produção e consumo cultural das crianças; mudanças na família e efeitos nas vidas das crianças, ou seja, dimensões que ampliam a reflexão sobre os espaços de experiências das crianças para além dos limites escolares.

Saber mais sobre os centros de pesquisa consolidados, nos quais experientes pesquisadores do campo da Sociologia da Infância produziram conhecimento sobre a infância, numa abordagem sociológica, na maioria das vezes, foi buscar compreender melhor como esses espaços de pesquisa funcionam. A discussão dos diferentes aspectos pelos quais procurei obter mais informação - contextos, interdisciplinaridade, produção de teoria ou o papel da educação num estudo interdisciplinar -, como se viu, pela própria dimensão, geraram novas possibilidades de realização de outras pesquisas.

Retomando a apresentação da tese, vejo a possibilidade de essas novas pesquisas serem realizadas aqui, com o objetivo de produzir alternativas teórico-metodológicas para a pesquisa da Sociologia da Infância no Brasil, iniciando, talvez, um novo ciclo de produção de pesquisa com outros países da América do Sul, mantendo interlocução com a produção europeia. Vamos ver. 


\section{Referências}

ABOELELA, S.W.; LARSON, E.; BAKKEN, S.; CARRASQUILLO, O.; FORMICOLA, A. Defining interdisciplinary research: conclusions from a critical review of the literature. Health Services Research. 42(1):329-46, 2007.

ALANEN, L. Theorizing childhood. Childhood, v.21(1), p.3-6, 2014.

ALANEN, L. Disciplinarity, interdisciplinarity and childhood studies. Childhood, v.19(4), p.419-422, 2012.

ALANEN, L. Rethinking childhood. Acta Sociologica, v .31, n.1, p.53-67, 1988.

ALANEN, L.; SIISIÄINEN, M. Fields and Capitals. Constructing local life. Jyväskylä: University of Jyväskylä. Finnish Institute for Educational Research, 2011.

ALDERSON, P. Childhood Real and Imagined. London, New York, Routledge, 2013.

ALMEIDA, R. P. W. Se essa escola fosse minha... A organização da educação infantil e o grupo de crianças em contexto escolar. 2009. 129p. Dissertação (mestrado). Pontificie Universidade Católica PUC, São Paulo.

ALVIM, M. R.; VALLADARES, L. Infância e sociedade no Brasil: uma análise da literatura. Boletim Bibliográfico e Informativo de Ciências Sociais 26: 3-43, 1988

BARROS, R.; CARVALHO, M.; FRANCO, S.; PÁDUA, E.; MENDONÇA, R.; ROSALÉM, A; TSUKADA, R. A importância da qualidade da creche para a eficácia na promoção da educação infantil. Brasília: Secretaria de Assuntos Estratégicos. Política de Promoção ao Desenvolvimento Integral na Primeira Infância, 2011a. Disponível em: <http://www.sae.gov.br/site/?page_id=10716>. Acesso em jan. 2013.

BARROS, R.; CARVALHO, M.; FRANCO, S.; MENDONÇA, R.; ROSALÉM, A. Uma avaliação do impacto da qualidade da creche no desenvolvimento infantil. Pesquisa $e$ planejamento econômico. Brasília, v.41, n.2, p.213-232, ago. 2011b.

BOBBIO, N. Left and Right: the significance of a political distinction. Cambridge, Polity Press, 1996. 
BOURDIEU, P.; PASSERON, J. C. A reprodução. Elementos para uma teoria do sistema de ensino. Rio de Janeiro: Francisco Alves, 1975

BREDA, B. É a escola o lugar da infância? Um estudo sobre o desenvolvimento da infância brasileira na legislação do século XX. Tese (Doutorado em Educação) - Faculdade de Educação da Universidade de São Paulo, 2015, 157p.

BREDA, B. Infância: imagens e memórias de adultos. Dissertação (Mestrado em Educação). Faculdade de Educação da Universidade de São Paulo, 2010, 136p.

CAHILL, C.; RIOS-MOORE, I.; THREATTS, T. Different eyes/open eyes: community-based Participatory Action Research. In: CAMMAROTA, J.; FINE, M. (eds.) Revolutionizing education: youth participatory action research in motion. London: Routledge, 89-124, 2008.

CAMPOS, M. M.; HADDAD, L.. Educação infantil: crescendo e aparecendo. Cadernos de Pesquisa. São Paulo: Fundação Carlos Chagas, n80 (fev/92), pp. 11-20, 1992

CARVALHO, A. M.A. e BERALDO, K. E.A. A interação criança-criança: ressurgimento de uma área de pesquisa e suas perspectivas. Cadernos de Pesquisa, São Paulo: FCC, 71: 5561, nov./1989

CASTRO, L. R. de; KOSMINSKY, E. Childhood and its Regimes of Visibility in Brazil. An Analysis of the Contribution of the Social Sciences. Current Sociology, v.58 (2), p.206231, Mar 2010.

CHRISTENSEN, P.; PROUT, A. Anthropological and sociological perspectives on the study of children. In: GREENE, S.; HOGAN, D. (eds.) Researching children's experience. Approaches and Methods. London: Sage, 2005, p.42-60

COOK, D. T. The promise of an unanswered question: multi-/cross-disciplinary struggles. Children's Geographies, v.8, n.2, p.221-222, May 2010.

CORSARO, W. A. Sociologia da Infância. Trad. Lia Gabriele Regius Reis. Porto Alegre: Artmed, 2011

CORSARO, W. A. Peer Culture. In: QVORTRUP, J.; CORSARO, W. A.; HONIG, M-S. The Palgrave Handbook of Childhood Studies. London: Palgrave, 2009, p.301-315. 
CORSARO, W. A. Reprodução interpretativa e cultura de pares. In: MÜLLER, F.; CARVALHO, A.M.A (orgs) Teoria e prática na pesquisa com crianças. Diálogos com William Corsaro. São Paulo: Cortez, 2009, p. 31-50

CORSARO, W. A. Entrada no campo, aceitação e natureza da participação nos estudos etnográficos com as crianças pequenas. Educação e Sociedade. Sociologia da infância: pesquisas com crianças. Campinas, v. 26, n. 91, p.443-464, mai./ago. 2005.

CORSARO, W. A. Collective Action and Agency in Young Children's Peer Cultures. In: QVORTRUP, J. (ed.) Studies in modern childhood: society, agency, culture. Hampshire/ New York: Palgrave Macmillan, 2005, p.231-247. (Versão em português disponibilizada pelo autor em 2007)

CORSARO, W.A. The Sociology of Childhood. Thousand Oaks, California: Pine Forge Press, 1997.

CORSARO, W. A. Young children's conception of status and role. Sociology of Education, v.52, n.1, p.46-59, jan.1979

CORSARO, W. A.; EDER, D. Children's peer cultures. Annual Review of Sociology, v.16, p. 197-220, ago. 1990.

CRUZ, S. H. V. A criança fala: A escuta de crianças em pesquisa. São Paulo: Cortez, 2008

DAHLBERG, G.; MOSS, P.; PENCE, A. Qualidade na Educação da Primeira Infância: perspectivas pós-modernas. Trad. Magda Franca Lopes. Porto Alegre: Artmed, 2003.

DELGADO, A. C. C.; MÜLLER, F. Apresentação/Organização Dossiê Tempos e Espaços das infâncias. Currículo sem Fronteiras, v. 6, n.1, p. 5-14. 2006

DELGADO, A. C. C.; MÜLLER, F. Apresentação/Organização do Dossiê Sociologia da Infância: pesquisa com crianças. Educação e Sociedade, Campinas, v. 26, n.91, p. 351360, 2005.

DELGADO, A.C.C. Culturas Infantis e Dimensões da Socialização no cotidiano de uma creche domiciliar. Cadernos de Educação (UFPel), FAE/UFPEL/PELOTAS, v. 21, n. ano 12, p. 101-118, 2003. 
DELGADO, A.C.C. O Referencial Curricular Nacional para a Educação Infantil e as políticas educacionais do final do século: uma análise sobre o papel social dos atores sociais e o lugar ocupado pelas questões socioculturais. Seminário Educação Infantil em Debate, NEPE. Revista do Núcleo de Estudo e Pesquisa em Educação de zero a seis anos, Rio Grande, RS, v. 1, p. 25-34, 1999.

DeMAUSE, L. The History of Childhood. New York, Psychohistory Press, 1974.

DUBAR, C. A Socialização: Construção das Identidades Sociais e Profissionais, São Paulo, Martins Fontes, 2005.

DUBET, F. Sociologia da Experiência, Lisboa, Instituto Piaget, 1994.

DURKHEIM, E. Educação e sociologia. 11 ed. São Paulo: Melhoramentos, 1978.

EMIRBAYER, M.; MISCHE, A. What is agency? American Journal of Sociology, v.103, n.4, p. 962-1023, jan. 1998.

FARIA, A. L.G. de; MELLO, S. (orgs.) Territórios da Infância: linguagens, tempos e relações para uma pedagogia para as crianças pequenas. Araraquara: Junqueira \& Marin, 2008

FARIA, A. L.G. de. O Coletivo Infantil em Creches e Pré-Escolas: Falares e Saberes. São Paulo: Cortez, 2007

FERNANDES, F. As "trocinhas" do Bom Retiro. In: FERNANDES, Florestan. Folclore e mudança social na cidade de São Paulo. Petrópolis: Vozes. 1979.

FERREIRA, M. "A gente gosta é de brincar com os outros meninos!": Relações sociais entre crianças num Jardim de Infância. Porto: Edições Afrontamento, 2004

FINE, M.; TUCK, J.E.; ZELLER-BERKMAN, S. Do you believe in Geneva? In: DENZIN N.; SMITH, L.T.; LINCOLN, Y. (eds.) Handbook of critical and indigenous knowledges. Beverley Hills, CA: Sage Publications, 2007.

FORTUNATI, A. A Educação Infantil como Projeto da Comunidade. Porto Alegre: Artmed, 2009

FRODEMAN, R.; KLEIN, J.T.; MITCHAM, C. (eds.) The Oxford Handbook of Interdisciplinarity. Oxford, UK, Oxford University Press, 2010 
FR ØNES, I. Dimensions of childhood. In QVORTRUP, J.; BARDY, M., SGRITTA, G, WINTERSBERger, W. (Eds.). Childhood Matters: Social Theory, Practice and Politics. Aldershot: Avebury. 1994

GAGEN, E. A. Disciplinary domains: searching out different ways of doing children's research. Children's Geographies, v.8, n.2, p.213-214, May 2010.

GAITÁN MUÑOZ, L. La nueva sociología de la infancia. Aportaciones de una mirada distinta. Política y Sociedad, V. 43, N. 1, p. 9-26, 2006

GIDDENS, A. Central Problems in Social Theory. Action, Structure and Contradiction in Social Analysis. London, Palgrave, 1979.

HARDMAN, C. Can there be an Antropology of Children? Childhood, n.8, p.501-517, nov. 2001. (Originalmente publicado em Journal of the Anthropological Society of Oxford. V.IV, n.2, p.85-99, 1973)

HECHT, T. At home in the street: street children of Northeast Brazil. Cambridge: Cambridge University Press, 1998.

HUTCHBY, I; MORAN-ELLIS, J. (eds.) Children and social competence. Arenas of action. London, The Falmer Press, 1998.

JACOBS, J. A.; FRICKEL, S. Interdisciplinarity: a critical assessment. Annual Review of Sociology, 35, p.43-65, 2009. Disponível em soc.annualreviews.org. Acesso em abril/2014.

JAMES, A. L. Competition or integration? The next step in childhood studies? Childhood, 17(4), p.485-499, 2010.

JAMES, A. (2013) Socialising Children. Houndmills, Basingstoke: Palgrave Macmillan

JAMES, A. Interdisciplinarity - for better or worse. Children's Geographies, v.8, n.2, p.215-216, May 2010.

JAMES, A. Agency. In: QVORTRUP, J.; CORSARO, W. A.; HONIG, M-S. The Palgrave Handbook of Childhood Studies. London: Palgrave, 2009, p.35-45. 
JAMES, A. Giving voice to children's voices: practices and problems, pitfalls and potentials. American anthropologist, 109 (2), p.261-272, 2007.

JAMES, A. Understanding childhood from an interdisciplinary perspective. Problems and potentials. In: PUFFAL P.B.; UNSWORTH, R.P. (eds.) Rethinking childhood. New Jersey, Rutgers University Press, 2004.

JAMES, A.; JAMES, A. L. Key concepts in childhood studies. London: Sage, 2008.

JAMES, A.; JENKS, C.; PROUT, A. Theorizing childhood. Cambridge: Polity Press, 1998

JAMES, A; PROUT, A. Constructing and Reconstructing Childhood. Contemporary issues in the Sociological Study of Childhood. London: Routledge Falmer, 1990.

JENKS, Chris. Constituindo a Criança. Educação, Sociedade e Culturas. Crescer e aparecer ou... para uma sociologia da infância. N. 17. Porto: Afrontamento, 2002, pp.185-216.

JENKS, C. (ed) The Sociology of Childhood: Essential Readings. London: Batsford, 1982.

KRAMER, S. A política do pré-escolar no Brasil. São Paulo: Cortez, 1995 (5 ed.)

LAHIRE, Bernard. The Plural Actor. Cambridge: Polity Press, 2011

LEE, N. Towards an immature sociology. The Sociological Review, 46(3), p.458-482, 1998.

MAYALL, B. A History of the Sociology of Childhood. London: Institute of Education Press, 2013.

MAYALL, B. An afterword: some reflections on a seminar series. Children's Geographies, 10:3, p.347-355, 2012.

MAYALL, B. Towards a Sociology for Childhood: Thinking from Children's Lives. Buckingham: Open University Press, 2002

MAYALL, B.; MORROW, V. You can help your country: English children's work during the Second World War. London: Institute of Education, University of London, 2011

MONTANDON, C. Sociologia da Infância: balanço dos trabalhos em língua inglesa. Cadernos de Pesquisa, São Paulo, n.112 p. 33-60, mar. 2001. 
MONTANDON, C. La Sociologie de l'enfance: l'essor des travaux en langue anglaise. Éducation et Sociétés, n.2, de 1998

MONTGOMERY, H. An introduction to childhood: anthropological perspectives on children's lives. Chichester: Wiley-Blackwell, 2009

MORROW, V. Judith Ennew: A personal tribute. Childhood, Vol. 21(2) 151- 160, 2014.

MOSS, P. Respecting the singularity of the child, resisting the society of control. Conferência apresentada no Congresso Internacional "Celebrating Childhood Diversity". Sheffield, UK, 2012. Disponível em http://www.cscy.group.shef.ac.uk/activities/conferences/index.htm Acesso em 30/agosto/2012.

MOSS, P.; PETRIE, P. From Children's Services to Children's Spaces. Public Policy, Children and Childhood. London: Routledge, 2002

NARODOWSKI, M. Infancia y poder: la conformación de la pedagogía moderna. 2aㅡ ed. Buenos Aires: Aique, 1999

NASCIMENTO, M. L. B. P. Como se conduz a pesquisa da infância quando a educação é mais um campo a compor seus estudos? Alguns elementos para discussão Currículo sem Fronteiras, v. 15, p. 79-93, 2015.

NASCIMENTO, M. L. B. P. Jens Qvortrup: A infância como fenômeno social. Educação (São Paulo), São Paulo, p. 68 - 82, 22 out. 2012a.

NASCIMENTO, M. L. B. P. Crianças pequenas e a produção de culturas In: GOBBI, Marcia A.; NASCIMENTO, M. L. B. P. (Orgs.). Educação e diversidade cultural: desafios para os estudos da infância e da formação docente. Araraquara - SP: Junqueira\&Marin Editores, 2012b, p. 68-89.

NASCIMENTO, M. L. B. P. O lugar da educação infantil na vida das crianças pequenas. Conferência I. VI Congresso Paulista de Educação Infantil, 2012c

NASCIMENTO, M. L. B. P. Sociologia da Infância e Educação Infantil: algumas considerações sobre a aproximação entre essas duas áreas na pesquisa sobre a pequena infância Horizontes (EDUSF), v. 27, p. 31-36, 2011 a. 
NASCIMENTO, M. L. B. P. Reconhecimento da sociologia da infância como área de conhecimento e campo de pesquisa: algumas considerações. In FARIA, A. L. G de; FINCO, D. Sociologia da Infância no Brasil. Campinas: Autores Associados, 2011b, p.37-54.

NASCIMENTO, M. L. B. P. A infância visível. Educação (São Paulo), São Paulo, p. 44 - 53, 15 maio 2009.

NASCIMENTO, M. L. B. P.; GOMES, L. O.; ALMEIDA, R. P. W.; BREDA, B.; ALBOZ, L.; SERRAO, C. R.; CORREIA, M. A. A.; SAMORI, D. P.; PRADO, R. L. C.; KLEIN, S. B. Infância e Sociologia da Infância: entre a invisibilidade e a voz: Relatório Científico. São Paulo: FEUSP, 2013.

NASCIMENTO, M. L. B. P; KLEIN, S.B. A interface entre a sociologia da infância e a educação infantil Anais Eletronicos III GRUPECI. Aracaju - SE: Anais Eletronicos III GRUPECI, 2012. p. 24-38.

OLIVEIRA, Z. M.R. Jogo de papéis: uma perspectiva para a análise do desenvolvimento humano. Tese (Doutorado em Psicologia). São Paulo: IPUSP, 1988

PAIN, R. Ways beyond disciplinarity. Children's Geographies, v.8, n.2, p.223-225, May 2010.

PARSONS, T. The social system. $2^{\text {nd }}$ ed. London: Routledge, 1991

PATTO, M. H. S. Da psicologia do desprivilegiado à psicologia do oprimido. In PATTO, M.H. S. Introdução à Psicologia Escolar. São Paulo: T.A. Queiroz, 1993, p. 208-228

PEDROSA, M.I. Interação criança - criança: um lugar de construção do sujeito. Tese (Doutorado em Psicologia). São Paulo: IPUSP, 1989.

PIRES, F. F.; NASCIMENTO, M.L.B.P. O propósito crítico: entrevista com Allison James. Educação e Sociedade. Campinas, v.35, n.128, p.631-950, jul/set. 2014.

PROUT, A. Taking a step away from modernity: reconsidering the new sociology of childhood. Global Studies of Childhood, v.1, n.1, p.4-14, 2011.

PROUT, A. Reconsiderando a nova sociologia da infância. Cadernos de Pesquisa, v.40, n.141, p.729-750, set./dez. 2010. 
PUNCH, S. Research with Children. The Same or Different from Research with Adults? Childhood, v.9, n.3, p.321-341, 2002.

PUNCH, S; TISDALL, K. Exploring children and young people's relationships across Majority and Minority Worlds, Children's Geographies, 10:3, 241-248, 2012

QUINTEIRO, J. Infância e educação no Brasil: um campo de estudos em construção. In FARIA, Ana L.G, DEMARTINI, Zeila B. F. E PRADO, Patricia D. (orgs). Por uma cultura da Infância metodologias de pesquisa com crianças Campinas: Autores Associados, 2a ed., 2005.

QUINTEIRO, J. A emergência de uma sociologia da infância no Brasil. Anais da 26ạ Reunião Anual da ANPEd, 2003

QUINTEIRO, J. Sobre a Emergência de uma Sociologia da Infância: contribuições para o debate. Perspectiva. Florianopolis, v. 20, p. 137-162, jan-jun/2002

QVORTRUP, J. Sociology of Childhood: Research Committee 53. A brief account of its formation by Jens Qvortrup. Newsletter of the Research Committee 53 Sociology of Childhood, ISA. February 2015, p.4-7.

QVORTRUP, J. Nove teses sobre "infância como um fenômeno social". Pró-Posições. Universidade Estadual de Campinas. Faculdade de Educação. Campinas: v.22, n.1, jan/abr./2011a, p. 199-211.

QVORTRUP, J. A tentação da diversidade - e seus riscos. Educação \& Sociedade. V.31, n.113, p.1121-1136, out./dez. 2010b

QVORTRUP, J. Infância e Política. Cadernos de Pesquisa, v.40, n.141, set./dez. 2010a, p.777-792

QVORTRUP, J. Are Children Human Beings or Human Becomings? A Critical Assessment of Outcome Thinking. Rivista Internazionale di Scienze Sociali, v.117 (3); p.631-654, $2009 b$

QVORTRUP, J. Childhood as a Structurall Form. In QVORTRUP, J.; CORSARO, W. A.; HONIG, M-S. The Palgrave Handbook of Childhood Studies. London: Palgrave, 2009a. 
QVORTRUP, J. Bem-estar infantil em uma era de globalização. In SAETA, B.R.P.; SOUZA NETO, J.C.; NASCIMENTO, M.L.B.P. Infância: volência, instituições e políticas públicas. São Paulo: Expressão e Arte, 2007.

QVORTRUP, J. Sociology of Childhood: Conceptual Liberation of Children. In MOURITSEN, F.; QVORTRUP, J. (eds.) Childhood and Children's Culture. Odense: Odense University Press, 2002.

QVORTRUP, J. Childhood and Societal Macrostructures. In GULDBERG, J.; MOURITSEN, F.; MARKER, T.K. Child and Children's Culture. Odense: Odense University, Department of Contemporary Cultural Studies, 1999

QVORTRUP, J. Childhood in Europe: a New Field of Social Research, pp.7-19 in CHISHOLM, Lynne et al. (eds.) Growing up in Europe. Berlin/New York: De Gruyter, 1995) QVORTRUP, J. "Nine Theses about Childhood as a Social Phenomenon". Eurosocial Report. Childhood as a Social Phenomenon: Lessons from an International Project. N.47. Vienna: European Centre/Sydjysk Universitetscenter, 1993, pp. 11-18.

QVORTRUP, J. Childhood as a Social Phenomenon: An introduction to a Series of National Reports. Eurosocial Report. Vienna: European Centre, v.36, 1991.

QVORTRUP, J. Introduction to Sociology of Childhood. International Journal of Sociology, v.17, n.3, 3-37, (special issue: 'The Sociology of Childhood'). Fall.1987.

QVORTRUP, Jens; CORSARO, W. A.; HONIG, M-S. Why Social Studies of Childhood? An introduction to the Handbook. In QVORTRUP, J.; CORSARO, W. A.; HONIG, M-S. The Palgrave Handbook of Childhood Studies. London: Palgrave, 2009.

QVORTRUP, J., BARDY, M., SGRITTA, G,; WINTERSBERGER, W. (Eds.). Childhood Matters. Social Theory, Practice and Politics. Aldershot: Avebury, 1994 (Public Policy and Social Welfare - European Centre Vienna, vol. 14

RINALDI, C. (2007) In dialogue with Reggio Emilia: listening, researching and learning. New York, NY: Routledge. 
RINALDI, C. (1999) O currículo emergente e o construtivismo social. In EDWARDS, C.; GANDINI, L; FORMAN, G. As cem linguagens da criança. Artmed, Porto Alegre, pp. 113122.

ROCHA, E. A.C. A pedagogia e a educação infantil. Revista Brasileira de Educação no 16. Campinas: Autores Associados, 2001, p. 27-34

ROCHA, E. A.C. A pesquisa em Educação Infantil no Brasil: trajetória recente e perspectivas de consolidação de uma pedagogia. Tese (Doutorado em Educação). Universidade Federal de Santa Catarina, Centro de Ciências da Educação, Núcleo de Publicações, 1999

ROSEMBERG, F. Educação: para quem? Ciência e Cultura, Campinas, v.28, n.12, p.1.4661.471, dez. 1976.

ROSEN, D. Child soldiers, international humanitarian law, and the globalization of childhood. American anthropologist, 109 (2), p.296-306, 2007.

RHOTEN, D. "Interdisciplinary Research: Trend or Transition," in 5, ed. (New York: Items \& Issues, Spring/Summer 2004), 1-2, 6-11.

SALTER L.; HEARN, A. (eds.) Outside the Lines: Issues in Interdisciplinary Research. Montreal: McGill-Queens Univ. Press, 1996

SARMENTO, M. J. Sociologia da Infância: correntes e confluências. In SARMENTO, M.; GOUVEA, M. C. S de. (Org.) Estudos da infância: educação e práticas sociais. Petrópolis: Vozes, 2008, p. 17-39

SARMENTO, M.; GOUVEA, M. C. S de. (Org.) Estudos da infância: educação e práticas sociais. Petrópolis: Vozes, 2008

SARMENTO, M. J. "Visibilidade social e estudo da infância”. In: VASCONCELLOS, V.M.R.; SARMENTO, M. J. (orgs.) Infância (In)visível. Araraquara: Junqueira \& Marin, 2007, pp. 25-49.

SARMENTO, M. J. As culturas da Infância nas Encruzilhadas da Segunda Modernidade. In: SARMENTO, M. J.; CERISARA, A. B. (orgs.) Crianças e Miúdos: Perspectivas sociopedagógicas da infância e educação. Porto: Edições ASA, 2004. p.9-34 
SARMENTO, M. Infância, exclusão social e educação para a cidadania activa. Movimento. Niteroi: UFF, FE/DP\&A Ed, n.3, p. 53-74, mai. 2001a.

SARMENTO, M. A globalização e a infância: impactos na condição social e na escolaridade. In GARCIA, R. L.; LEITE FILHO, A. (Org.). Em defesa da educação infantil. Rio de Janeiro: DP\&A editora, 2001b, p. 13-28.

SARMENTO, M.; SILVA, R.; COSTA, S. Infância, trabalho e identidade social. Psicologia Clínica. Rio de Janeiro, v.12, n.2, p.47-63, 2000.

SARMENTO, M.; PINTO, M. As crianças e a infância: definindo conceitos, delimitando o campo. In PINTO, M.; SARMENTO, M. (coord.) As Crianças: Contextos e Identidades. Braga. Centro de Estudos da Criança da Universidade do Minho, 1997.

SEWELL Jr, W. H. A theory of structure: Duality, agency, and transformations. American Journal of Sociology, v.98, n.1, p.1-29, jul.1992.

SIROTA, R. L'enfance au regard des Sciences sociales. AnthropoChildren [online]. V.1, n.1, Jan. 2012. Disponível em http://popups.ulg.ac.be/2034-8517/index.php?id=893 Acesso em março/2012.

SIROTA, R. Primeiro os amigos: os aniversários da infância, dar e receber. Educação e Sociedade. 2005, vol.26, n.91, p. 535-562

SIROTA, R. Emergência de uma sociologia da infância: evolução do objeto e do olhar. Cadernos de Pesquisa, São Paulo, n.112 p. 7-31, mar. 2001.

SIROTA, R. L'emergence d'une sociologie de l'enfance: evolution de l'object, evolution du regard, Éducation et Sociétés, n.2, de 1998

STRENZEL, G. R. A produção científica sobre educação infantil no Brasil nos programas de pós-graduação em educação. 23ạ REUNIÃO ANUAL DA ANPEd, 2000, Caxambu. Anais...Rio de Janeiro: ANPEd, 2000.

THORNE, B. Crafting the interdisciplinary field of childhood studies. Childhood, 14, p.147-152, 2007. 
TISDALL, E.K.M. Taking forward children and young people's participation. In: HILL, M; HEAD, G.; LOCKYER A.; REID, B. and TAYLOR, R. (eds.) Children's services: working together. Harlow: Pearson, 2012, p. 151-162.

TISDALL, E. K. M.; PUNCH, S. Not so 'new'? Looking critically at childhood studies. Children's Geographies, 10:3, p.249-264, 2012.

VANDENBROECK, M. Vamos discordar. Trad. Tatiane Cosentino Rodrigues. Revista Eletrônica de Educação. São Carlos, SP: UFSCar, v.3, no. 2, p. 13-22, nov. 2009. Disponível em http://www.reveduc.ufscar.br Acesso em 09/agosto/2012

ZUSMAN, M; KNOX, D.; GARDNER, T. The social context view of Sociology. Durham: Carolina Academic Press, 2009. 